\title{
LOS USOS DE LA TABERNA: RENTA FISCAL, COMBATE AL ALCOHOLISMO Y CACICAZGO POLÍTICO EN CHILE. $1870-1930^{2}$
}

\begin{abstract}
El presente artículo examina los debates y medidas establecidas en Chile a partir de las últimas décadas del siglo XIX para regular la producción, expendio y consumo de bebidas alcohólicas, concentrándose en los intereses políticos y productivos que este tipo de discusiones y medidas permiten interpretar. Junto con exponer las principales estrategias establecidas por el Estado para conseguir una renta permanente a partir del impuesto a las bebidas alcohólicas, se analizan las prácticas políticas que, en el nivel municipal, vinculaban a los expendedores de bebidas embriagantes con la actividad política electoral, concluyéndose que este tipo de relaciones entorpecieron la aplicación efectiva de aspectos centrales de la legislación antialcohólica implementada durante el periodo en estudio.
\end{abstract}

Palabras clave: bebidas alcohólicas, impuestos, historia social, historia política, historia económica.

The present article examines the debates and measures established in Chile since the last decades of the 19th century to regulate the production, expense and consumption of alcoholic beverages, being concentrating on the productive and political interests that this type of discussions and measures permit to interpret. Along with exposing the main strategies established by the State to obtain a permanent income from the tax to the alcoholic beverages, the political practices are analyzed that, in the municipal level, linked the dealers of beverages with the electoral political activity, being concluded that this type of relations they hindered the effective application of central aspects of the anti-alcoholic legislation implemented during the period in study.

Key words: alcoholic beverages, taxes, social history, economic history.

\footnotetext{
1 Universidad Alberto Hurtado, Santiago de Chile. Correo electrónico: mfernandez@uahurtado.cl

2 Este artículo es parte de la investigación elaborada en el marco de la realización de la Tesis Doctoral para obtener el grado de Doctor en Historia en la Pontificia Universidad Católica de Chile, "Historia Social del Alcoholismo en Chile. 1870-1930. Políticas, prácticas, representaciones". El proceso de indagación y redacción contó con el valioso aporte de CONICYT, DIPUC, MECESUP, el Center for Latin American and Caribbean Studies de la State University of New York at Stony Brook y SEPHIS (South-South Exchange Program for Research on the History of Development), instituciones a quienes manifiesto mi agradecimiento. Junto a ello, agradezco los valiosos comentarios de los profesores Thomas Miller Klubock, Julio Pinto V. y Juan Eduardo Vargas C.
} 


\section{INTRODUCCIÓN}

En el concurso que el Ministerio de Hacienda convocó en 1897 para la elaboración de una legislación concerniente a las bebidas alcohólicas en Chile, se definieron dos objetivos centrales: el diseño de medidas tendientes a combatir el alcoholismo y la adquisición de una renta fiscal para el Estado. De tal forma, ambas tareas estuvieron, desde ese momento, íntimamente ligadas, y esta unidad determinó la fortuna de unas y otras. Esta dependencia fue, desde un inicio, fuertemente criticada, en tanto que la obtención de recursos de parte del Estado a partir de la industria, el comercio y el consumo de bebidas alcohólicas implicaba -a juicio de las organizaciones temperantes- lucrar con los vicios del pueblo, y peor aún, asegurar la existencia de los embriagantes antes que eliminarlos de una vez. Por otro lado, la vinculación legislativa entre cargas impositivas y medidas de combate directo al alcoholismo provocó que los debates se alargasen, no tanto por la discusión de las medidas destinadas a combatir el consumo inmoderado de embriagantes, sino por las posiciones difíciles de conciliar que existían sobre el impuesto, sus fuentes, montos y destino. Con habilidad, las distintas administraciones relacionaron explícitamente la imposición de tributos específicos al alcohol con medidas generales de prevención y represión del beber inmoderado, así como de protección a la vitivinicultura y fomento de la exportación, constituyendo cuerpos legales que más que leyes eran verdaderos códigos; el articulado impositivo se ligaba a medidas de corte policial, educativo y terapéutico.

Ello no impidió, sin embargo, que al interior del Parlamento se diesen largas batallas a favor o en contra de las propuestas de tributación, quedando de manifiesto el fuerte apoyo con que contaban las organizaciones de productores de vinos al interior de la corporación legislativa. Este apoyo se tradujo en que el impuesto a los vinos fuese aplicado de forma progresiva y tardía en relación a aquel que afectaba a los alcoholes destilados, como queda de manifiesto al contemplar que, en las distintas legislaciones, los cambios más significativos eran referidos a este ítem: de forma general, la estructura de las leyes de 1902, 1916 y 1929 no se modificó sustancialmente en lo concerniente a la represión de la embriaguez, la interdicción del ebrio habitual o la clausura de tabernas. El monto de los impuestos, sus alcances, sus obligaciones: tales fueron los temas que, de alguna forma, justificaban la transformación legislativa.

La creación de la Administración del Impuesto sobre los Alcoholes fue una medida considerada en la ley de alcoholes de 1902 que modificó la estructura impositiva del país, que descansaba en los derechos de aduana y un pequeño canon sobre la propiedad de la tierra, además del cobro de una tasa por el papel sellado, el derecho de timbres y las estampillas ${ }^{3}$. Ello obligó al diseño y constitución de una burocracia que daría origen, a poco andar el tiempo, al Servicio de Impuestos Internos, que tomaría bajo su cargo este y otros impuestos. Es decir, la novedad de

3 Carlos Humud, "Política Económica Chilena, desde 1830 a 1930", en Estudios de Economía, $\mathrm{N}^{\circ} 3,1974,42$ y ss. 
la tributación sobre los alcoholes no se redujo al ámbito de la lucha contra el alcoholismo, sino que también a la modificación de las estructuras internas del Estado, su administración y las fuentes de recursos con las que contaba para cumplir sus tareas y objetivos. De forma paralela, la ampliación de esferas de influencia de la acción estatal se evidenciaba en la ley de alcoholes -expropiación de derechos civiles y parentales, posibilidad de internamiento médico, subvención de la familia del ebrio habitual- y los recursos con los cuales sustentar esta ampliación eran definidos por esta nueva legislación tributaria. Este fenómeno, que ahora revisaremos en el plano estrecho de la legislación y las medidas antialcohólicas, bien puede aplicarse al conjunto de las relaciones entre Estado y sociedad que se desarrollaron a partir de los primeros años del siglo XX. El análisis de las estrategias impositivas que sigue busca iluminar en ese sentido. Pero antes de ello, es importante detenerse en las formas en las cuales los gobiernos locales obtuvieron recursos, antes y en paralelo a la aplicación del impuesto, gracias a la práctica social del consumo de bebidas alcohólicas.

\section{LAS PATENTES MUNICIPALES SOBRE LOS LUGARES DE EXPENDIO}

Una de las fuentes de crítica permanente -de parte de las organizaciones temperantes y las autoridades centrales $-{ }^{4}$ con respecto a las posibilidades efectivas de regulación de las tabernas y despachos de bebidas alcohólicas, era el hecho de que las patentes de funcionamiento de este tipo de establecimientos dependían de las administraciones municipales. Los recursos por ese ítem obtenidos formaban parte del financiamiento regular de las autoridades locales, a las que por lo mismo se les cuestionaba una convivencia de intereses que hacía dudosa su sincera disposición a participar activamente en la lucha antialcohólica. Independiente de estos juicios contemporáneos, la importancia de las patentes de expendio en los presupuestos municipales nunca fue determinante, pero no por ello menor ${ }^{5}$. Del mismo modo, los cuerpos legislativos sobre alcoholes -como normativas de alcance nacionalestablecieron valores fijos para las patentes de expendio, como forma de moderar la discrecionalidad que al respecto mantenían las autoridades locales.

Desde el inicio de los años que abarca este estudio, hemos obtenido información que menciona el cobro de contribuciones a los expendios de bebidas alcohólicas de parte de distintos municipios. Por ejemplo, en el reglamento para el cobro de contribuciones de serenos de la villa de Salamanca se indicaba que los despachos de licores pagarían como propiedades de segunda clase, por debajo tan solo

4 Con respecto a las organizaciones temperantes, ver de mi autoría "La virtud como militancia: las organizaciones temperantes y la lucha antialcohólica en Chile. 1870-1930", en Cuadernos de Historia, $\mathrm{N}^{\circ} 26,2006$ (en prensa).

5 Esta afirmación la hacemos considerando la información aportada por Markos Mamalakis y que ofrecemos unas páginas más adelante. Con respecto a las restantes fuentes de financiamiento municipal durante gran parte del siglo XIX, ver Ricardo Nazer Ahumada, "Las finanzas municipales chilenas: 1833-1887", en Historia $\mathrm{N}^{\circ} 32,1999,265-314$. 
de las grandes propiedades y las tierras de primer orden. A la tercera, cuarta y quinta clase de contribuyentes correspondían los despachos al por menor, los bodegones y las pulperías, respectivamente ${ }^{6}$. Del mismo modo, algunas municipalidades contaban con el remate de derechos para la instalación de fondas, con ocasión de las celebraciones patrias, como un ítem permanente en sus presupuestos: Valparaíso consignaba 741 pesos por chinganas y diversiones públicas para $1873^{7}$. Los Andes asignaba a este objeto un monto de 300 pesos para $1874^{8}$. De igual modo, Limache consideraba en su presupuesto para 1874,550 pesos obtenidos por las patentes de chinganas ${ }^{9}$. El municipio de Rancagua hacía subir este mismo ítem hasta los 1.000 pesos, bajo el concepto de fondas del departamento, en su presupuesto para $1875^{10}$. Esta vez en San Felipe, y como contribución destinada al sustento de la policía de seguridad y el alumbrado público, se establecía que las destiladoras de aguardiente pagarían el segundo mayor monto -solo tras las fábricas de jarcia, actividad predominante en la zona-, en tanto que las fábricas de cerveza, de vinos y licores espirituosos colaborarían en una escala algo inferior, pero por sobre la media de otras actividades como los establecimientos destinados a la elaboración de alimentos o carruajes ${ }^{11}$. Con el mismo fin, la municipalidad de Curicó estableció las más altas contribuciones a las destilerías, seguidas por las fábricas de cerveza, los despachos de licores en la tercera clase, las fondas en cuarta clase y los bodegones en la quinta ${ }^{12}$.

Solo en 1892 encontramos una legislación que establezca algún tipo de criterio general para el conjunto del país en relación al cobro de patentes a los expendios de bebidas alcohólicas. Para tales efectos, la normativa dividió al territorio en cinco órdenes, estableciéndose en cada uno de ellos una diferencia entre establecimientos de primera, segunda y tercera clase: por ejemplo, los establecimientos de primera clase del primer orden pagarían la mayor contribución, que alcanzaba a 1.200 pesos al año, en tanto que los de tercera clase del último orden cancelarían solo 75 pesos. Quedaban comprendidos bajo la facultad de esta norma todos los establecimientos que expendieran bebidas alcohólicas destiladas o fermentadas ${ }^{13}$. A modo de ejemplo, una publicación temperante de Valparaíso nos informa la cantidad de establecimientos en cada una de las clases establecidos en el puerto,

6 Ministerio de Interior (en adelante MINT), Vol. 659, mayo de 1873. Reglamento para el cobro de contribuciones de serenos de la Villa de Salamanca.

7 MINT, Vol. 660, noviembre de 1872. Presupuesto de la Municipalidad de Valparaíso para 1873.

8 MINT, Vol. 659, noviembre de 1873. Presupuesto de la Municipalidad de Los Andes para 1874.

9 MINT, Vol. 660, noviembre de 1873. Presupuesto de la Municipalidad de Limache para 1874

10 MINT, Vol. 700, noviembre de 1874. Presupuesto de la Municipalidad de Rancagua para 1875 .

11 MINT, Vol. 659, noviembre de 1873. Proyecto de ordenanza para la contribución de la policía de seguridad i alumbrado público de la ciudad de San Felipe.

12 MINT, Vol. 701, diciembre de 1873. Reglamento para la contribución de sereno i alumbrado público en la ciudad de Curicó.

13 "Lei que establece el Impuesto de Patente para los establecimientos en que se espendan bebidas destiladas o fermentadas", Santiago, 11 de agosto de 1892, en Revista Chilena de Higiene (en adelante $R C h H$ ), tomo I, $\mathrm{N}^{\circ} 2,1894,447-449$. 
que estaba dentro de las zonas del primer orden: 56 de primera clase, 157 de segunda y 759 de tercera, que en conjunto debían de reportar al municipio cerca de quinientos mil pesos cada año ${ }^{14}$.

Algunos ecos de la discusión de esta ley ponen de manifiesto que el fin último que sus promotores buscaban era encarecer el consumo de bebidas alcohólicas, así como castigar económicamente a las industrias que se dedicaban a su fabricación. De acuerdo con el ministro del Interior responsable de esta iniciativa, Ramón Barros Luco, este efecto de aumento de los costos del licor para los consumidores generaría los mismos buenos resultados que se podían observar en Inglaterra, donde a partir de esta medida el consumo de alcoholes se había estancado en los últimos cincuenta años, misma situación que se constataba en Francia, Alemania y Austria. Por otro lado, el diputado conservador Carlos Risopatrón Argomedo argumentaba a favor del alza de dichas patentes para los comercios de embriagantes, preguntándose: “¿Por qué no ha de pagar 2.000 pesos una industria como el expendio de licores, que es productiva para su dueño, perniciosa para el público i a la cual se trata de poner cortapisas?"15.

De forma coordinada, en el año de 1892 se establecieron normativas de carácter nacional que tanto imponían nuevas contribuciones a los locales de expendio de bebidas embriagantes, como los reglamentaban en su horario de funcionamiento. Sin embargo, la aplicación efectiva de las regulaciones y el cobro de las patentes quedaban en manos de los municipios, que fortalecían con ello las atribuciones de autonomía en el gobierno local establecidas en la Ley de Comuna autónoma de $1891^{16}$

Por otro lado, la falta de discriminación en el cobro de patentes a los expendios que vendían bebidas destiladas y aquellos que solo comerciaban con fermentadas generó una inmediata reacción de parte de los productores vitivinícolas, o al menos así lo deja interpretar el hecho de que a fines de ese año se hacía una modificación de la ley, en artículo único, que expresaba: “...se suspenden los efectos de la lei de 8 de agosto de 1892, para los establecimientos que expendan bebidas cuya base de alcohol no pase de 15 por ciento, los cuales pagarán un tercio de la patente establecida por la lei citada" ${ }^{17}$. Más aún, para un comentarista algo posterior la normativa

14 La Cinta Azul, $\mathrm{N}^{\circ} 16$, septiembre de 1892.

15 Citados en La Cinta Azul, $\mathrm{N}^{\circ}$ 16, septiembre de 1892.

16 "...la lei de autonomía comunal, alentadora de los intereses i de las pasiones lugareñas, desorganizadora e inoportuna, en el $\mathrm{N}^{\circ} 3$ de su artículo 34, es la primera en establecer, a beneficio de los municipios, un impuesto sobre las bebidas alcohólicas i sobre el tabaco. La lei de 8 de agosto de 1892 que estableció las facultades mencionadas en la lei anterior, se dictó a instancias del interés partidista que impuso el municipio autónomo, sin el estudio previo que requería; por eso, antes de entrar en vigencia, ya fue modificada, i en cierto modo destruida, por la lei del 31 de diciembre del mismo año. No es posible decir cuánto ha producido este impuesto a pesar de que en las memorias ministeriales suelen darse algunos cálculos, porque, hoy por hoy, las finanzas municipales son las más oscuras manchas de nuestras instituciones, laberinto en el cual nadie se ha aventurado sin extraviarse, por lo cual han quedado en todo autónomas, libres de todo examen, exentas de toda fiscalización". J. Modesto I. de M., Observaciones a la Lei de Alcoholes, Santiago de Chile, Imprenta i Encuadernación del Comercio, 1902, 12-13.

17 "Lei que modifica la Lei que establece el Impuesto de Patente para los establecimientos en que se espendan bebidas destiladas o fermentadas", Santiago, 31 de diciembre de $1892, R C h H$, tomo I, N ${ }^{\circ}$ $2,1894,450$. 
“...tropezó con la tenaz oposición de los cantineros i demás perjudicados con ella"18. Otro autor concluía que esta nueva indicación solo facilitó el incumplimiento en la práctica de la ley, puesto que no era difícil ocultar las botellas de destilados y declarar que solo se vendían fermentados. Del mismo modo, se confirmaba, a su juicio, la influencia de taberneros y productores vinícolas en los municipios, en tanto las administraciones locales no habían hecho nada por dar cumplimiento estricto a la normativa original -que no distinguía entre los distintos tipos de bebidas-, aun cuando ello les significaba perder importantes cantidades de dinero en recaudación ${ }^{19}$. Algún tiempo después, el periódico temperante La Cinta Azul se quejaba, con ocasión de las fiestas de fin de año de 1893, que la ordenanza del cobro de patentes “.... solo ha servido para dar a los municipios una renta cuantiosa, dejando vivo i latente el mal que se pretende corregir, y creemos que ha estado muy distante del espíritu de nuestros legisladores convertir ese vicio en una fuente de recursos municipales sin resultado alguno favorable para el bienestar o la moralidad pública" ${ }^{20}$. Para las fiestas patrias del año 1894 , nada parecía cambiar, denunciándose que “...pagándose los derechos que cobra la Ilustre Municipalidad, se puede envenenar a medio mundo; todo es cuestión de precio. Ya lo sabían los partidarios de la completa libertad industrial y comercial" 21 .

Lo cuantioso de este tipo de ingresos era materia de duda para otro de nuestros comentaristas, en tanto quedaba de manifiesto que el monto posible de recaudar había sido disminuido a solo un tercio del valor potencial, dado que quien vendía destilados tendía a declarar que solo expendía fermentados. Ilustrando esta situación, el autor explicaba que en el año 1896 los municipios habían recolectado por este rubro la módica suma -que bastaba parta molestar a los temperantes- de poco más de 280.000 pesos, en tanto que con la misma normativa, pero sin excepciones, en Argentina el mismo año el Fisco había recaudado en 1895 más de seis millones de pesos 22 .

Dejando en evidencia el relativo fracaso de las normativas que buscaban encarecer el costo del expendio de bebidas embriagantes y su consecuente consumo por parte de los sectores más pobres de la sociedad, el mensaje presidencial que iniciaba la tramitación de la ley de alcoholes de 1902 indicaba que "...la experiencia ha venido a demostrar, sin embargo, que el número de estos establecimientos no disminuye de una manera sensible i que el pago de las fuertes patentes establecidas no es obstáculo para que el consumo continúe adquiriendo mayores proporciones" 23 . Otro autor comentaba, cerca ya de finalizar el siglo XIX, que los munici-

18 Daniel Bernales L. Comentarios sobre la Lei $N^{\circ} 1515$, Memoria de prueba para optar al grado de licenciado en la Facultad de Leyes y Ciencias Políticas de la Universidad de Chile, Santiago de Chile, Imprenta i Encuadernación Universitaria, 1907, 19.

19 Benjamín Dávila L. El alcoholismo i la reglamentación de las bebidas alcohólicas, Santiago de Chile, Imprenta Nacional, 1899, 68.

$20 \quad$ La Cinta Azul, $\mathrm{N}^{\circ} 30$, febrero de 1894.

21 La Cinta Azul, $\mathrm{N}^{\circ} 37$, septiembre de 1894. Cursivas en el original.

22 Hermógenes Pérez de Arce, Alcohol $i$ alcoholismo. Primera parte de la memoria presentada al certamen del Ministerio de Hacienda, Santiago de Chile, Imprenta Nacional, 1899, 116 y 160.

23 Boletín de Sesiones Ordinarias del Senado (en adelante BSOS), 1895, 14 de junio de $1895,42$. 
pios efectivamente no se interesaban en controlar de forma estricta a las tabernas y su correspondiente pago de patentes, interpretándose que ello obedecía a un interés de parte de las autoridades locales en no aplicar las leyes puestas a su alcance para el control de las tabernas y la obtención de recursos económicos, por inexplicable que ello pudiese parecer ${ }^{24}$. Otra fuente que buscaba conocer la cifra total de tabernas existentes en el país por medio del registro nacional de patentes, explicaba que ello no era posible, pues esta estadística estaba “...en absoluto falseada por los diversos rubros con que se ocultan los lugares en que se expenden bebidas alcohólicas i porque quedan sin anotarse i sin pagar patente una cifra enorme de pequeñas tabernas" 25 . Ejemplo de ello era el caso de la ciudad de Santiago, que de acuerdo a datos de la Intendencia, contaba en 1899 con 1.743 expendios que pagaban patente, y 1.817 que no lo hacían ${ }^{26}$. Por lo mismo, en un proyecto destinado al saneamiento de la ciudad, se solicitaba el aumento en el valor de las patentes entregadas -que alcanzaba solo a 67.000 pesos y de acuerdo a sus autores podría ascender al quíntuplo de dicha cifra- así como a la fiscalización de su efectivo pago ${ }^{27}$.

Como forma de detener este tipo de abusos algunos plantearon la posibilidad de que las patentes de tabernas y cantinas fuesen concedidas solo a organizaciones temperantes: tal medida no prosperó, en tanto se vio en ello la aniquilación y no la reglamentación de este tipo de establecimientos ${ }^{28}$. Una opinión alternativa planteaba, desde una posición menos beligerante, la conformación de comisiones que aprobasen la licitación de estas patentes, conformadas por autoridades municipales, judiciales y de la Junta de Beneficencia, sin posibilidad de que, una vez fallecido el concesionario, pudiese heredarse su privilegio, el cual debía de rematarse nuevamente, lo mismo en caso de que el propietario quisiese vender o arrendar el expendio ${ }^{29}$. Efectivamente, la discusión de este tópico ocupó algún lugar en el debate parlamentario conducente a la ley de 1902, en tanto la Comisión Especial encargada de su estudio estimó necesario terminar con las diferencias existentes entre los expendios de destilados y fermentados, "por la posibilidad de fraudes y su proliferación", recomendando ubicar a los comercios de vinos y cervezas en la última categoría de pago general ${ }^{30}$. Finalmente, el título quinto de la Ley $\mathrm{N}^{\circ} 1.515$ estableció la misma jerarquización de cinco órdenes territoriales y tres clases de expendios, cuyas patentes representaban montos que iban también desde los 1.200 pesos a los 75 pesos. Estos valores serían el mínimo de inicio del remate público de licitación que se realizaría cada tres años en las respectivas municipalidades.

24 Eliodoro Yáñez, "La cuestión de los alcoholes. Exposición presentada a la Cámara de Diputados por el señor Eliodoro Yañez, diputado por Valdivia" Documentos Parlamentarios, Santiago de Chile, Imprenta Nacional, 1899, 69.

25 Benjamín Dávila L., op. cit. 23-24.

26 José del Pozo, Historia del vino chileno, Editorial Universitaria, Santiago de Chile, 1999, 166.

27 RChH, tomo VII, 1902, 269.

28 La Temperancia, $\mathrm{N}^{\circ} 30$, enero de 1895.

29 Marcial Martínez de Ferrari, "Determinación de la pureza de los alcoholes", en Revista Médica de Chile (en adelante RMCh.), tomo XX, 1892, 121.

30 Boletín de Sesiones Extraordinarias del Senado (en adelante BSES), 1901-1902, sesión 34ª en 11 de diciembre de 1901, 722-726. 
Del mismo modo, la ley establecía como motivos de preferencia para la adjudicación de las licencias de expendio el mayor precio ofrecido, la solicitud hecha de parte de una sociedad de temperancia, o por el contrario, que fuera propuesta por un comerciante con experiencia en el ramo, pero sin condena dentro del último año por violación de las disposiciones de la ley. En caso de ser un concesionario reemplazado en el remate, tendría la posibilidad de continuar con el negocio hasta por seis meses, pagando para ello la porción de la patente correspondiente. Una vez adjudicadas, las patentes podrían transferirse por causa de muerte, disolución de la sociedad legalmente constituida o quiebra ${ }^{31}$.

Es decir, la primera legislación de carácter nacional sobre el particular no modificaba el estatuto de las municipalidades con respecto al control y beneficio del comercio de embriagantes, ni aumentaba el costo de las patentes ni comprendía las críticas que las normativas de 1892 habían provocado, salvo en el caso de los expendios de fermentados, que en esta ocasión quedaban en igual posición legal que los de destilados. Por lo mismo, los cuestionamientos no demoraron en llegar, incluso desde la misma Administración del Impuesto a los Alcoholes, de acuerdo con cuyo responsable los abusos ya se hacían evidentes, puesto que algunos municipios efectuaban remates fuera del plazo legal y, lo que era más grave, subastaban grandes cantidades de patentes de las clases inferiores -de menor costo- y ninguna de primera clase, sabiendo que eran justamente estas últimas las que sí permitían el alza efectiva del precio de las bebidas puestas a disposición del público, objetivo implícito de la nueva ley. Del mismo modo, denunciaba el funcionario, podían verse en la prensa avisos de venta de este tipo de licencias, pasándose por alto las facultades de selección de los ponentes que la municipalidad tenía como deber hacer respetar ${ }^{32}$. Como consecuencia de ello, según la misma fuente, “...el precio de venta de los licores no supera al que regía antes de la ley. Es casi seguro que el consumo en las cantinas es hoy el mismo que hace dos años"33.

Para 1903, de acuerdo a datos oficiales, habían sido rematadas en todo el país 281 patentes de primera clase, 556 de segunda y 1.330 de tercera, número manifiestamente menor a la cantidad de expendios repartidos a lo largo y ancho del territorio nacional. De acuerdo con el Administrador del Impuesto a los Alcoholes, esto se debía al hecho de que las normas de la ley se burlaban de manera flagrante y sistemática, puesto que los lugares en que se vendía alcohol para ser consumido fuera de ellos generalmente contaban con cuartos interiores donde realizar el consumo (los "clandestinos"), por la falta de sanciones penales a los contraventores, y “...principalmente a la poca importancia que las autoridades administrativas y las policías han dado a la ley, permitiéndose el libre funcionamiento de negocios al por menor sin patente..." 34 . Con respecto a esto último, otro autor recordaba que

31 Lei sobre alcoholes promulgada en el Diario Oficial de 16 de enero de 1902, Santiago de Chile, Imprenta Nacional, 1902, 20-23.

32 Primera Memoria del Administrador del Impuesto sobre Alcoholes presentada al Ministerio de Hacienda, Santiago de Chile, Imprenta y Encuadernación Universitaria, 1903, 104-105.

33 Ibid, 127.

34 Segunda Memoria del Administrador del Impuesto sobre Alcoholes presentada al Ministerio de Hacienda, Santiago de Chile, Imprenta y Encuadernación Universitaria, 1906, 29. 
“...la falta de patente respectiva no está sancionada en la ley con pena alguna y, por tanto, no constituye delito para el dueño del negocio" 35 . Sin embargo, la misma autoridad que hacía las críticas señaladas más arriba seguía confiando en la bondad de las patentes para remediar el problema del alcoholismo, en tanto consideraba que el sistema de remates podría encarecer efectivamente el costo de las bebidas puestas a disposición de los consumidores, de tal forma de que

...el vicio será el que determine el mayor precio a que se adquiera el derecho a establecer un local de expendio. No es el licitador o rematante, por otra parte, el que paga el precio de su autorización. Es el consumidor el que indirectamente, por fracciones insensibles, ha de costear el valor de la licencia. Si no hay interesados en el remate, tanto mejor para el país, pues cada vez que el sistema tributario se vea restringido por esta causa, podemos afirmar que el vicio disminuye, y que el arraigado alcoholismo de hoy tiende a desaparecer ${ }^{36}$.

Sin embargo, y a pesar de las esperanzas en la autorregulación del mismo mercado de las patentes que tenía el funcionario de la Administración del Impuesto, el común de los observadores consideraron que la nueva legislación a la larga disminuía el costo de las patentes y "...se convirtió en un estímulo para establecer tabernas" 37 , por el hecho de que siendo los pagos trienales, bajaban los montos finales de recaudación a un nivel "ridículo" 38 . Por tales razones, el diputado demócrata Malaquías Concha consideró que, comparada con la represión de la ebriedad y la imposición de trabajos forzosos a sus infractores, las medidas tomadas por los municipios con respecto a las patentes eran débiles, interesadas y de poco impacto real en el objetivo de disminuir el consumo y, sobre todo, la cantidad de tabernas instaladas en sus jurisdicciones ${ }^{39}$. A la larga, y tal como lo planteaba otro autor ya en 1910, el gran problema de la aplicación efectiva de la concesión de patentes como forma de disminuir el número de tabernas radicó en que estas se mantuvieron en manos de las municipalidades, que encontraban en las tabernas una parte significativa de sus apoyos políticos locales. Por ello, las patentes debían pasar a administración fiscal, así en su licitación como en los recursos que generaban ${ }^{40}$. En esas mismas fechas el

35 Luis M. Rodríguez A. Observaciones sobre la Ley de Alcoholes $N^{\circ} 1515$ de 18 de enero de 1902 en cuanto interesa a los servicios de la Policía de Seguridad, Memoria de prueba presentada a la Universidad de Chile para optar al grado de licenciado en la Facultad de Leyes y Ciencias Políticas. Santiago, Imprenta de la Prefectura de Policía, 1904, 22.

36 Segunda Memoria del Administrador del Impuesto sobre Alcoholes presentada al Ministerio de Hacienda, op . cit., 67.

37 Boletín de la Sociedad Nacional de Agricultura (en adelante BSNA), Vol. XXXVII, N ${ }^{\circ} 32$, diciembre de 1906,825-833.

38 Daniel Bernales L., op. cit. 35.

39 Boletín de Sesiones Ordinarias de la Cámara de Diputados (en adelante BSOCD), 1908, sesión 24a en 18 de junio de 1908, 660-662.

40 Hernán Correa R. El alcoholismo y la lei, Memoria de prueba para optar al grado de Licenciado en Leyes y Ciencias Políticas de la Universidad de Chile, Santiago de Chile, Imprenta Universitaria, $1910,41-42$. 
diputado conservador por Valparaíso Alfredo Rodríguez Rozas opinaba, en vistas a la reforma de la ley, que "...las Municipalidades son las autoridades menos aptas para hacer cumplir esta lei, porque además de los intereses políticos que hai envueltos en esta cuestión de las cantinas, son ellas las que se benefician con las patentes que pagan estos establecimientos" ${ }^{41}$. Además, se informaba que a pesar de disponer la ley de que parte de los fondos recaudados fueran usados en medidas para combatir la embriaguez, esta obligación no era cumplida “...con rarísimas excepciones o tal vez sin excepción..." por las autoridades locales ${ }^{42}$.

Con la legislación de 1916 ningún elemento relevante a este particular fue modificado, y desde la normativa, se debió esperar hasta 1925 para que se introdujeran algunos cambios de forma en el régimen de patentes, como aquellas que señalaban algunos sitios de las ciudades donde podían ubicarse los expendios de distinta clase, la tasación de las patentes industriales de las fábricas de bebidas alcohólicas (desde 1.000 hasta 200 pesos), y los montos de las distintas patentes de expendio, que se elevaron desde los cien hasta los dos mil pesos ${ }^{43}$. Una confirmación tanto de la importancia relativa de los ingresos por patentes de expendios de bebidas alcohólicas para los presupuestos municipales, como del crecimiento sostenido y constante global de este tipo de ítem de contribuciones puede observarse en la siguiente tabla, elaborada con datos calculados por Markos Mamalakis.

TABLA 1

MONTOS RECAUDADOS POR LOS MUNICIPIOS CHILENOS POR CONCEPTO DE PATENTES DE EXPENDIOS DE BEBIDAS ALCOHÓLICAS, Y PORCENTAJE DE LOS PRESUPUESTOS MUNICIPALES TOTALES REPRESENTADOS POR ESTE ÍTEM. $1902-1925^{44}$.

\begin{tabular}{lccc}
\hline Año & $\begin{array}{c}\text { Monto recaudación patentes } \\
\text { expendios de bebidas alcohólicas } \\
\text { (pesos) }\end{array}$ & $\begin{array}{c}\text { Total ingresos } \\
\text { municipales } \\
\text { (pesos) }\end{array}$ & $\begin{array}{c}\text { Porcentaje del total de los } \\
\text { presupuestos municipales recau- } \\
\text { dados por patentes de expendios }\end{array}$ \\
\hline 1902 & 497.672 & 10.141 .719 & 4.9 \\
1903 & 352.020 & 9.222 .798 & 3.8 \\
1904 & 385.184 & 10.268 .401 & 3.7 \\
1905 & 366.333 & 8.944 .037 & 4.1 \\
1906 & 438.888 & 14.651 .626 & 3.0 \\
1907 & 720.594 & 18.885 .475 & 3.8 \\
1908 & 995.809 & 20.813 .194 & 4.8 \\
\hline
\end{tabular}

41 BSOCD, 1910, sesión 30a en 26 de julio de 1910, 969-970. A la misma conclusión llegaba la Comisión conformada para el estudio de la reforma de la legislación, que además proponía el alza del valor de las patentes. Boletín de Sesiones Extraordinarias de la Cámara de Diputados (en adelante $B S E C D), 1910$, sesión $15^{\text {a }}$ en 28 de noviembre de 1910, 434-440.

42 Guillermo Tapia C. La reforma de la Lei de Alcoholes, Memoria de prueba para optar al grado de licenciado en la Facultad de Leyes i Ciencias Políticas de la Universidad de Chile, Santiago de Chile, Imprenta El Progreso, 1916, 15.

43 Ordenanzas sobre establecimientos de expendio de bebidas alcohólicas y artículos de consumo, Santiago de Chile, Imprenta Chile, 1925, 9, 55 y 69-71.

44 Markos Mamalakis, Historical statistics of Chile. Vol. VI, Government Services and Public Sector and a Theory of Services, Greenwood Press, NY, Connecticut, London, 1989. 374-375. 


\begin{tabular}{lccc}
\hline Año & $\begin{array}{c}\text { Monto recaudación patentes } \\
\text { expendios de bebidas alcohólicas } \\
\text { (pesos) }\end{array}$ & $\begin{array}{c}\text { Total ingresos } \\
\text { municipales } \\
\text { (pesos) }\end{array}$ & $\begin{array}{c}\text { Porcentaje del total de los } \\
\text { presupuestos municipales recau- } \\
\text { dados por patentes de expendios }\end{array}$ \\
\hline 1909 & 1.106 .441 & 13.949 .418 & 7.9 \\
1910 & 692.953 & 18.209 .180 & 3.8 \\
1911 & 1.779 .424 & 24.054 .933 & 7.3 \\
1912 & 1.677 .859 & 22.655 .925 & 7.4 \\
1913 & 1.652 .277 & 27.520 .105 & 6.0 \\
1914 & 1.507 .561 & 25.620 .849 & 5.8 \\
1915 & 1.149 .589 & 27.858 .162 & 4.1 \\
1916 & 1.206 .302 & 29.567 .314 & 4.0 \\
1917 & 1.114 .280 & 42.604 .962 & 2.6 \\
1918 & 1.220 .571 & 44.418 .896 & 2.7 \\
1919 & 1.391 .275 & 44.015 .043 & 2.7 \\
1920 & 1.235 .702 & 45.356 .836 & 3.1 \\
1921 & 1.170 .937 & 37.469 .703 & 3.9 \\
1922 & 1.250 .646 & 43.296 .792 & 2.2 \\
1923 & 1.375 .679 & 44.525 .103 & 2.3 \\
1924 & 1.462 .206 & 65.752 .762 & \\
1925 & 1.714 .576 & 72.012 .197 & \\
\hline
\end{tabular}

Como se puede observar en la tabla, los montos recaudados por los municipios chilenos a los expendios de bebidas alcohólicas mantuvieron un crecimiento sostenido desde 1902 hasta 1909, es decir, en los primeros años de la aplicación de la legislación que establecía un monto fijo para cada tipo de patentes a nivel nacional. Tras una brusca caída en 1910 , los montos se estabilizan en cifras cercanas al millón y medio de pesos, iniciando una nueva alza a partir de 1924. Sin olvidar el factor inflacionario que afectó al país a partir de la década de 1910, es importante constatar que si bien los presupuestos globales de los municipios crecieron de forma más evidente que los ingresos específicos del ítem de patentes de expendios, la participación de este en el total se mantuvo por lo general cercana al cuatro por ciento del total, siendo más bien excepcionales los años con mayores porcentajes, o menores a $3 \%$.

Ello nos hace pensar que, si bien los municipios no dependían significativamente de este tipo de entradas, su importancia radicaba en que, y tal como ya hemos aludido y detallaremos al final de este capítulo, los expendios eran un sitio de atracción para clientelas políticas valiosas en tiempos de elecciones. Asimismo, y en base a la percepción de los contemporáneos de que las tabernas no dejaban de aumentar a pesar del costo de las patentes, es importante indicar que, como lo sugieren las cifras en su relativa estabilidad, ello se debía a que las autoridades locales licitaban mayor número de patentes de bajo valor, por lo que los ingresos se mantenían a costa de la proliferación de las cantinas de tercera, cuarta o quinta clases. Por lo mismo, la legislación de 1929 no alteró la base fundamental del funcionamiento de las cantinas, argumento que en el fondo explica el fracaso de esta medida como forma de controlar el consumo de alcoholes: se dejó en manos de los municipios la realización de los remates de patentes, y por ello, ante los 
intereses electorales de los mismos, las tabernas no dejaron de aumentar, quejándose inclusive los mismos dueños de expendios de que, ya en la década de 1930, la venta de cerveza se verificaba en lugares como pastelerías y fruterías, sitios que no pagaban ningún tipo de canon por el expendio de embriagantes ${ }^{45}$.

Es decir, y tras décadas de aplicación, la política de cobro de patentes terminó beneficiando solo a las municipalidades, que no utilizaron las facultades que les entregaba la ley para reducir el número de establecimientos de expendio de bebidas alcohólicas, sino que, por el contrario, encontraron en ello una forma de aumentar sus ingresos, fortaleciendo por añadidura los vínculos que se establecían entre la generación electoral de los municipios y el papel que en dicho proceso tenían los dueños de tabernas. Por lo tanto, para los interesados en el combate contra el alcoholismo y las autoridades fiscales, fue imperioso hallar una solución económica que al mismo tiempo significase un alza efectiva en el costo de las bebidas alcohólicas, y por otra, generase directamente recursos al Estado central, puesto que los dineros de patentes y multas por ebriedad quedaban a disposición de las administraciones locales. La solución encontrada fue el impuesto, cuyo desarrollo pasamos a reseñar.

\section{EL IMPUESTO A LOS ALCOHOLES: ANTECEDENTES Y DISCUSIÓN}

La historia del impuesto sobre los alcoholes aplicada en Chile a partir de la Ley $\mathrm{N}^{\circ} 1.515$ de 1902 es larga y compleja. Por eso, en este primer acápite revisaremos los antecedentes inmediatos a su establecimiento en el país, así como la extensa y documentada discusión que se dio en las múltiples memorias que al respecto se presentaron al concurso que el Ministerio de Hacienda convocó sobre el particular en 1897. A continuación revisaremos la aplicación efectiva del impuesto, sus subsiguientes reformas y los debates que las precedieron, así como el papel que los principales interesados -productores, autoridades, grupos de temperancia y médicos- jugaron en la crítica y evaluación de su implementación. Junto a lo anterior, reseñaremos los principales efectos económicos que la medida impositiva tuvo en las industrias dedicadas a la fabricación de bebidas embriagantes.

En la década de 1870 , las propiedades dedicadas a la fabricación de bebidas alcohólicas destiladas y los viñedos productores de vinos no pagaban más que las contribuciones territoriales que indicaba la ley, por propiedad industrial o catastro por propiedad de la tierra ${ }^{46}$. La primera propuesta para modificar esta situación que hemos logrado pesquisar provino desde la Sociedad de Fomento Fabril, que en septiembre de 1887 presentó a las autoridades un proyecto que buscaba establecer un impuesto de cincuenta centavos por litro a todas los aguardientes producidos en

45 El problema del alcoholismo. La opinión del gremio de expendedores de bebidas alcohólicas.Una nueva política en la materia. Otros tópicos del Memorial presentado a los señores ministros de Hacienda y de Agricultura. Asociación de dueños de bares, restaurants y hoteles de Chile, Imprenta Virginia, Santiago, 1936, 11.

46 BSNA, Vol. IV $\mathrm{N}^{\circ}$ 21, agosto de 1873, 391-396; José del Pozo, op. cit., 175. 
el país, impuesto cuyo rendimiento se dividiría en un $60 \%$ para el Fisco y el restante quedaría a disposición de los municipios, entidades encargadas de su cobro. Para el autor que informaba sobre la existencia del proyecto, este debía de representar un primer paso que condujera, con el tiempo, a la medida que consideraba la única realmente efectiva para el control por parte del Estado del consumo inmoderado de bebidas alcohólicas en Chile: la implantación del monopolio ${ }^{47}$.

Es decir, desde un inicio en la discusión acerca de las medidas impositivas puestas a disposición -teóricamente- del Estado, se presentaron dos alternativas opuestas, representadas por la posibilidad de la determinación de un impuesto, o por el contrario, el establecimiento del monopolio de parte del Estado, con lo cual controlaría de forma exclusiva ya fuera la producción o la comercialización de las bebidas embriagantes. Como veremos más adelante, ambas opciones fueron defendidas por distintos autores, prevaleciendo a fin de cuentas la determinación de un impuesto sobre la producción. Sin embargo, y antes de que tal medida se verificara por medio de una ley, ante las primeras proposiciones, y en particular la que acabamos de citar emanada desde la SOFOFA, las voces de crítica no se demoraron en surgir. En 1887 el Boletín de la Sociedad Nacional de Agricultura nos informaba de la alarma causada por tal propuesta entre los destiladores agrícolas del sur de Chile, que consideraban al impuesto proyectado "exorbitante", en tanto calculaban -y así lo hacían saber al Presidente de la República- que en caso de tener que pagar cincuenta centavos por litro de aguardiente producida, sus costos subirían de tal manera que, en el plazo de dos meses, habrían pagado en impuestos las misma cantidad de dinero en que calculaban el valor total de sus instalaciones industriales. Como alternativa, planteaban bajar la contribución al 10\% del valor efectivo del litro de aguardiente. De otra forma, la medida afectaría gravemente el desarrollo de las destilerías industriales de la zona, y más aún, las actividades a ellas asociadas, como la agricultura y la ganadería y sus derivados, provocándose “...un malestar económico profundo en todas las demás industrias de la región”48.

Para otros autores, el volumen del gravamen no era alto, y más aún, no debía de cobrarse de acuerdo a la capacidad declarada de producción de las industrias -como lo recomendaba el proyecto de la SOFOFA-, sino que en relación a la producción efectiva, por medio de contadores automáticos instalados en los alambiques. Logrado ello, e incluso bajando el impuesto a treinta centavos por litro de aguardiente industrial producida, seguiría siendo un impuesto comparativamente bajo al que se pagaba en otras latitudes, y podría reportar un mínimo de dos millones de pesos para el Fisco ${ }^{49}$.

Con motivo de la convocatoria al concurso destinado a elaborar un proyecto de ley sobre el particular, a partir de 1897 se multiplicaron los estudios destinados a encontrar la mejor forma en que el Estado pudiese controlar la ebriedad a nivel

47 Vicente Dagnino O. "El alcoholismo en Chile", Memoria de prueba para optar al grado de Licenciado en la Facultad de Medicina i Farmacia, leída el 6 de julio de 1887, Santiago de Chile, Imprenta Nacional, 1888, en Anales de la Universidad de Chile, 1888, 13-14.

48 BSNA, Vol. XVIII, $\mathrm{N}^{\circ} 23$, septiembre de 1887, 751.

49 Hermógenes Pérez de Arce, op. cit. 163 y 167-168. 
social, al mismo tiempo que se hacía de una renta estable y contundente. Con tal fin se escribieron ensayos que se pronunciaban a favor del monopolio o el impuesto, de distintas formas y en distintas fases de la producción, comercialización y fiscalización de las bebidas alcohólicas. Por ejemplo, para Hermógenes Pérez de Arce, el establecimiento de un impuesto sobre los alcoholes era justo, equitativo y una necesidad social, aun considerando las opiniones de Zorobabel Rodríguez -una de las figuras más influyentes del pensamiento económico en el Chile del siglo XIX-, quien consideraba que los impuestos tenían como fin único la adquisición de rentas fiscales, y no la morigeración de las costumbres ${ }^{50}$. Un impuesto, y no así el monopolio, era la alternativa recomendada por el autor, en tanto que rechazaba la intromisión directa del Estado en la gestión de un “....negocio tan erizado de tentaciones desmoralizadoras, como lo es el de las bebidas que alimentan el vicio de la embriaguez" 51 . En la práctica, Pérez de Arce se manifestaba partidario de un impuesto sobre la producción efectiva de las bebidas producidas por destilación industrial, por medio del uso de contadores mecánicos continuos. El monto a pagar alcanzaría los treinta centavos por litro de alcohol producido, sea cual fuese su graduación $^{52}$.

Como una forma de participar en esta discusión, la Sociedad Nacional de Viticultores presentaba, en 1897, su propia propuesta de impuesto sobre el vino, que fijaban en dos centavos por hectárea cultivada de viñas -no producción efectiva-, dineros los cuales, en todo caso, deberían de ser utilizados para el pago de primas de exportación y el fomento de la industria vitivinícola ${ }^{53}$. Para el tema de los alcoholes destilados, en una sesión de fines de 1895, la misma asociación se había mostrado a favor de que el Estado se hiciese cargo del monopolio de la comercialización y la rectificación de los alcoholes, es decir, la fiscalización de su pureza y calidad $^{54}$. Así, los viticultores se manifestaban de acuerdo con un bajo impuesto a los vinos, y con una intervención decidida del Fisco sobre sus más importantes competidores, las destilerías industriales de alcohol. Esta posición fue defendida de forma sistemática por los productores de vino, en particular en el punto sobre la diferencia de montos que debían existir entre el impuesto de los destilados y aquel cobrado sobre su propia producción.

En relación a la implementación de un monopolio, otro autor consideraba factible el establecimiento de "destilerías concesionadas", que producirían la cantidad de alcohol dispuesta por el Estado y de acuerdo a sus exigencias. En un estadio inferior se encontrarían -dadas las características de la producción nacional de alcoholes agrícolas- las "destilerías secundarias", que estarían obligadas a vender sus pequeñas producciones a aquellas concesionadas. Los recursos por medio de estas operaciones adquiridos -en donde el Estado sería el efectivo comercializador del producto, dado que controlaría el negocio de la destilación a gran escala y concentraría la adquisi-

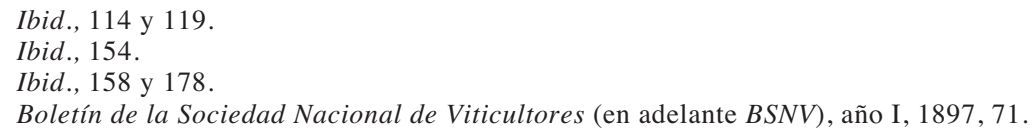


ción de la producción menor- serían, de acuerdo a este autor, destinados en una fracción del $12 \%$ a la “...creación de asilos para ebrios, hospitales para alienados de origen alcohólico, para sostenimiento de las familias de los mismos, para propaganda contra el abuso de espirituosos, para fomento de sociedades de temperancia, para publicación de obras adecuadas sobre alcoholismo, etc..." 55 . El estadístico Francisco de Béze, en fecha muy cercana, proponía también el establecimiento del estanco en beneficio del Estado, ya no sobre la producción, sino sobre el comercio de los alcoholes destilados ${ }^{56}$. La gran virtud que tenía esta alternativa monopólica sobre otra estrategia impositiva radicaba, de acuerdo a sus defensores, en que el Estado lograba por medio del control de la rectificación y el expendio proveer de bebidas sin adulteración y depuradas de las impurezas que se relacionaban fisiológicamente con los estragos del beber inmoderado. Asumiéndose una legislación monopólica coherente con lo anterior, el Estado podría proporcionar un alcohol "poco ofensivo" a los consumidores, desarrollar las pequeñas destilerías agrícolas, que solo harían ventas al Estado, y obtener una importante ganancia fiscal, que permitiría, en palabras del doctor Joaquín Talavera, autor de esta propuesta, “...quitar todo impuesto a las bebidas, como el vino, la sidra, la cerveza y otras llamadas higiénicas, porque son indispensables al trabajador que necesita de ellas para poder sobrellevar las fatigas de un día de cansancio" 57.

Para otro de los participantes del concurso de Hacienda, Jorge Rodríguez Cerda, la solución al problema presentado pasaba por el establecimiento del monopolio estatal sobre la rectificación y distribución al por mayor del alcohol producido. Sin embargo, y antes de detallar esta posición, es importante destacar que, para este autor, existía un vicio de fondo en la misma proposición de cualquier ley de combate al alcoholismo que mezclara tal objetivo con la adquisición de una renta fiscal, en tanto

"El día en que el Estado hubiera de equilibrar sus presupuestos con los recursos arrancados a la ebriedad, al alcohol, al vicio, en ese mismo día cesará en Chile, como ha cesado en todas partes, la idea de moralizar; los fríos guarismos de las entradas i de los gastos ahogarán los impulsos generosos de elevar la condición desgraciada de nuestros obreros, i concluirán entonces los sistemas que tienden a impedir la venta de alcohol nocivo, para ser sustituidos por los que le produzcan mayores rendimientos al Estado" 58 .

54 Ibid., 179.

55 Adeodato García V., El alcohol i las bebidas espirituosas. Su reforma legal i social, Santiago de Chile, Imprenta, Litografía i Encuadernación Barcelona, 1898, 106-108. Un 3\% restante de 1a cantidad recaudada, el autor recomendaba se utilizase en el mantenimiento de una Oficina de Estadísticas específica para la producción y venta del alcohol.

56 Francisco de Béze, El Alcoholismo. Estudio y estadística. Dedicado al señor Don Domingo Amunategui Rivera, Ministro de Justicia e Instrucción Pública, Santiago de Chile, Imprenta Moderna, 1897, 19-20.

57 Joaquín Talavera, El alcoholismo. Tomado de los archivos del Consejo Departamental de Higiene de Valparaíso, Valparaíso, Imprenta y Litografía Central, 1896, 11.

58 Jorge Rodríguez C. La cuestión del alcoholismo. El monopolio o el impuesto, Memoria $\mathrm{N}^{\circ} 26$ Premiada por el Supremo Gobierno en el certamen abierto por decreto de 14 de abril de 1897. Edición Oficial. Santiago de Chile, Imprenta Nacional, 1899, 2-4. 
Por ello, la alternativa del monopolio, a pesar de lo odiosa que podía parecer ante el principio de la libertad de industria, era legítima, más aún si estaba “...de por medio la salud pública, la conservación de la raza, la estabilidad de la familia i la felicidad de la sociedad". Como ejemplos, citaba los casos de Suiza, Rusia y los países escandinavos, en donde el monopolio se aplicaba sobre la fabricación, rectificación o distribución y expendio. Para Rodríguez Cerda, el Estado, “...siendo mal comerciante, todavía mui mal industrial, puede ser buen rectificador", es decir, recibir toda la producción del país, confirmar su estado de pureza y ausencia de toxicidad. Así, el Estado establecería o concesionaría grandes destilerías-rectificadoras, en donde el alcohol producido y rectificado se embotellaría en recipientes solo utilizados por el Estado, lo que le permitiría controlar la oferta efectiva de alcohol en el país. Los comerciantes y fabricantes de licores que utilizaran este alcohol deberían pagar patentes anuales, a más de los costos del alcohol y su rectificación, calculando por ello el autor una cifra de al menos quince millones de pesos como ingreso mínimo al Estado, de los cuales recomendaba que el 5\% fuese destinado a la lucha contra el alcoholismo ${ }^{59}$.

Por último, los doctores Luis Navarrete y Conrado Ríos establecieron en su propuesta al Ministerio de Hacienda una solución de compromiso, que incorporaba tanto la aplicación de un impuesto como la implementación del monopolio sobre la rectificación y la distribución. Para ellos, el mejor sistema estaba representado por la concentración por parte del Estado no de la producción de alcoholes, sino de su compra, rectificación y distribución, logrando con ello el control efectivo de la cantidad de alcohol disponible en el mercado nacional, y así, la determinación de su precio de venta. Sin embargo, reconocían que las condiciones efectivas de aplicación de tal medida en Chile eran complejas, por la larga tradición agrícola de pequeñas destilerías locales, y la facilidad de burlar la ley y producir alcoholes adulterados sin rectificar. Como estrategia de solución de este problema, los doctores Navarrete y Ríos plantearon la convivencia de ambos sistemas impositivos: el monopolio en las provincias salitreras -dotadas solo de grandes destilerías-, y el impuesto en el resto del país. De ese modo se controlaría la distribución al por menor en el ítem precios y la cantidad y calidad de lo expedido, medidas que serían reforzadas por la concesión de licencias de comercialización a "personas de responsabilidad y solvencia", y no a taberneros inescrupulosos interesados en aumentar sus ventas antes que en la salud de sus clientes.

Por lo mismo, la obligación de la rectificación eliminaría los alcoholes nocivos, y con ellos, a sus productores, que no serían competitivos. Sí, puesto que la proposición de Navarrete y Ríos consistió, junto al monopolio en el norte, en establecer la escala del impuesto en razón inversa al precio de las materias primas utilizadas en la destilación i en razón directa de su grado de toxicidad e impurezas. Es decir, si se utilizaban materias primas más baratas se pagaba menos impuesto, y mientras más puro el alcohol obtenido, menos impuesto también se pagaría. Con ello lo que buscaban era fortalecer la producción de alcohol de uvas, considerado el menos tóxico, y

$59 \quad$ Ibid., 170-172; 301-324. 
así no dañar a la industria vitivinícola. Conjuntamente, los vinos, cervezas y chichas quedaban exentos de cualquier tributación. El monto del impuesto -que no se atrevían a formular exactamente por falta de experiencia al respecto- debía lograr que los aguardientes fueran más caros que sus competidoras directas, las bebidas fermentadas, respetando la ley económica básica del principio de la sustitución del producto gravado por otro de menor toxicidad ${ }^{60}$.

Aun cuando la decisión de la comisión encargada de evaluar las memorias y proyectos de ley propuestos para la resolución del tema del alcoholismo en 1898 consideró que el sistema de monopolio "...no puede ser recomendado como sistema de iniciación, especialmente en un país como el nuestro, cuya administración no ha alcanzado aún el adelanto de los países europeos en los que ha sido implantado con éxito dudoso"61, la discusión de la opción monopólica llegó hasta el Parlamento, en donde el voto de minoría de la Comisión Especial encargada del análisis del tema se manifestó de acuerdo con el estanco estatal de la importación y el expendio al por mayor, ámbitos ambos que serían concesionados por las autoridades. Defendida por Silvestre Ochagavía -a la sazón diputado conservador por Llanquihue-, la propuesta buscaba tanto asegurar la producción de alcoholes nacionales -gravados con un impuesto de quince centavos por litro- como ahorrar al Estado la burocracia necesaria de implementar en caso de que se aprobase la alternativa del impuesto, que requería de cientos de funcionarios que deberían fiscalizar el cumplimiento de la normativa fiscal. De acuerdo al viticultor y diputado, era preferible dejar esa responsabilidad a un dueño -el concesionario- que a empleados asalariados ${ }^{62}$. Poco tiempo después, el diputado conservador representante de la zona de Constitución, José Miguel Echenique, profundizaba las razones que a su juicio hacían preferible el monopolio al impuesto: los costos que la administración del impuesto representarían agotarían o disminuirían significativamente los recursos recaudados; la disminución del consumo no se conseguiría, puesto que por la imposibilidad de un control estricto de parte de los funcionarios de la administración del impuesto, el alza del precio de los alcoholes motivada por el impuesto provocaría el desarrollo de la producción clandestina de alcoholes, de menor precio y peor calidad. Junto a ello, los espacios de corrupción funcionaria parecían inevitables, pues, se preguntaba el diputado, “¿Dónde encontrar una llave o una caja de seguridad, para encerrar a sus funcionarios dentro de los límites del deber, sin dar oídos a las asechanzas del interés, ni a los halagos del compadrazgo?"63.

60 Luis A. Navarrete (secretario de la Intendencia General del Ejército) y Dr. Conrado Ríos V. (Cirujano de la Escuela Militar i de la Academia de Guerra). El alcohol, el alcoholismo i su represión, Memoria presentada al concurso abierto por el Ministerio de Hacienda por decreto de 14 de abril de 1897 i designada para el primer premio ex-aequo por la comisión informante, Santiago de Chile, Imprenta Nacional, 1899, 144-146; 171-172; 231-253.

61 Adeodato García V., El alcohol i las bebidas espirituosas. Su reforma legal i social, op. cit., p. iv.

62 BSOCD , 1899, sesión $6^{\mathrm{a}}$ en 17 de junio de $1899,128$.

63 Idem, sesión $38^{\mathrm{a}}$ en 30 de agosto de $1899,811-815$. 
De forma similar, el diputado radical por Santiago Enrique Mac-Iver se manifestó partidario del sistema sueco, en donde el Estado era el único expendedor de los alcoholes ${ }^{64}$. Y el diputado demócrata por Valparaíso y Casablanca, Ángel Guarello, consideró, en rechazo al impuesto, que lo que la ley de alcoholes debía buscar era solamente la lucha contra la embriaguez, dado que Chile no tenía “...necesidad de recurrir a estas fuentes extraordinarias de entradas para subvenir a los gastos públicos", proponiendo por ello la creación del Estanco sobre los Alcoholes, que significaría que el Estado sería el único comprador y expendedor de alcoholes: los productores, grandes y pequeños, venderían su producción solo al Estado, y del mismo modo este controlaría las vías de importación, reducidas exclusivamente a los puertos de Valparaíso e Iquique. Los recursos así obtenidos se dedicarían al financiamiento de la instrucción primaria fiscal ${ }^{65}$. Es decir, la alternativa del monopolio les pareció factible y deseable a grupos importantes de parlamentarios, representantes de distintos intereses regionales y partidarios. Por ello, al votarse por primer vez en la Cámara de Diputados entre la opción monopolio o impuesto, la primera salió vencedora por 24 votos contra nueve y una abstención, lo cual motivó la conformación de una Comisión dedicada a la elaboración de un proyecto de monopolio estatal. Esta comisión estuvo conformada, entre otros, por Eliodoro Yáñez, Arturo Alessandri, José Miguel Echenique, Silvestre Ochagavía y Gonzalo Urrejola ${ }^{66}$. Sin embargo, el primero de los diputados nombrados repuso el proyecto original que había conducido la discusión desde un inicio, centrado en el impuesto, y el debate en torno al monopolio no volvió a prosperar ${ }^{67}$.

Es decir, hasta poco más de un año antes de aprobarse una ley definitiva, la opción del monopolio rondó por las Cámaras como una alternativa ajustada a derecho y a los intereses del Fisco chileno. Sin embargo, la estrategia elegida fue la aplicación de un impuesto y la creación de un órgano administrativo a cargo de su administración, opción que podemos interpretar se debió, en el fondo, al temor de importantes sectores del Parlamento -y de los intereses políticos y económicos ahí representados- a la creación de un organismo estatal con amplios poderes de intervención sobre la industria productora de bebidas embriagantes. Y este temor se puede explicar, asimismo, por la inveterada desconfianza en la asignación de mayores cuotas de poder a un Estado que amplios sectores del conservadurismo y el liberalismo suponían como ajeno tanto a los temas del desenvolvimiento industrial como de aspectos que se consideraban de exclusiva competencia de los individuos. Por último, y como algunos parlamentarios no dudaban en expresar, la implementación del monopolio supondría la contratación de un gran número de funcionarios estatales, los cuales podrían operar como efectivos agentes de la intervención electoral.

64 Idem, sesión $38^{\text {a }}$ en 30 de agosto de $1899,818-819$.

65 Boletín de Sesiones Extraordinarias de la Cámara de Diputados (en adelante BSECD), 1899 , sesión $19^{\text {a }}$ en 22 de noviembre de 1899,445 y $B S O C D, 1899$, sesión $38^{\circ}$ en 30 de agosto de $1899,822-825$

66 BSECD, 1899, sesión 19a en 22 de noviembre de 1899,448 y sesión $25^{\text {a }}$ en 1 de diciembre de 1900,583 .

67 BSOCD, 1900, sesión $27^{\text {a }}$ en 25 de junio de $1900,372-373$. 
Independiente de lo anterior, en no pocas de las memorias presentadas al Ministerio de Hacienda en 1897 la alternativa del impuesto era vista como la más adecuada, en tanto cumplía, a ojos de sus defensores, las dos características principales deseadas por el Ejecutivo: la represión del alcoholismo por medio del alza en el costo de las bebidas alcohólicas, y la generación de una renta fiscal abundante y sustentable en el tiempo. Un ejemplo interesante es el caso del doctor Ricardo Dávila Boza, que redactó una de estas memorias, en la cual se manifestaba partidario del impuesto y en contra del monopolio. Las razones de su rechazo al estanco estatal se relacionaban con su opinión de que el alcohol fabricado por el Estado no representaría las necesidades de la demanda, limitándose con ello la producción; además, el Estado sería un fabricante caro, pues la falta de competencia le eximiría de la búsqueda de las materias primas y procesos de fabricación más baratos, abriéndose con ello las puertas a la importación de alcoholes extranjeros más baratos, y peor aún, cerrándose los caminos de la exportación del alcohol nacional, encarecido por la ineficiencia relativa del Estado-productor. Por último, la implantación del monopolio obligaría al Estado a hacer enormes inversiones iniciales, tanto en la indemnización de los privados hasta ese momento dedicados a la industria, como en la construcción de gigantescas destilerías, la contratación de funcionarios y el establecimiento de una red de distribución al por menor que cubriese a toda la nación ${ }^{68}$.

Por el contrario, para el mismo autor, el impuesto -que recomendaba aplicar no solo a los alcoholes destilados, sino que ".... a todos los productos que contengan siquiera una centésima de alcohol, sin excepción alguna, cualesquiera que sea su origen i la forma i nombre con que se entreguen al consumo"- tenía beneficios concretos, en particular al ser cobrado sobre el producto final y no en las etapas anteriores (materias primas, rectificación, etc.). El mayor valor de una medida de esta naturaleza radicaba, a juicio de Dávila Boza, en que el Estado no interferiría en las decisiones productivas de los destiladores, y que el gravamen se aplicaría proporcionalmente al volumen de producción: es decir, el productor buscaría aumentar la cantidad de su producción al menor costo posible, para así disminuir el impacto del impuesto sobre el precio final de su alcohol. Con respecto a la fiscalización necesaria, sería fácil de ejercer sobre los grandes establecimientos de destilería, con el auxilio de una cantidad no excesiva de empleados, que generarían al Estado muchos menos costos que los beneficios asociados a su buen desempeño.

Como no es difícil de advertir, esta definición del impuesto como un obstáculo que obligaba a las destilerías a ser más productivas y competitivas entre sí, y por ello bajar el costo de producción del alcohol, no redundaría a la larga en un aumento significativo del precio del licor, que era el objetivo original de la carga impositiva. Y ello era explicado por el doctor Dávila Boza como un argumento

68 Opinando sobre el particular, la redacción del Boletín de la SNA argumentó en contra del monopolio en los siguientes términos: “...tiene el inconveniente de aparecer como institución colectivista $\mathrm{i}$, por lo tanto, peligrosa, i además se teme que con él, en vez de reducir la producción de alcohol, el Estado la favorezca para crear extraordinarios e inmediatos recursos en casos urgentes. Por eso se ha dicho que el alcohol es un tesoro de guerra". BSNA, Vol. XXXII, N 41, octubre de 1901, 827-837. 
positivo, en tanto que así se aseguraba una renta para el Estado y se impedía la aparición de múltiples formas de adulteración y comercio clandestino, motivados por el alza de precios provocada por el impuesto. Por último, recomendaba como monto de este un centavo por cada grado alcohólico presente en cada litro de alcohol destilado: es decir, un aguardiente corriente pagaría entre 35 y 40 centavos, y un litro de alcohol absoluto, entre 96 centavos y un peso. Con ello, el médico calculaba un rendimiento de ocho a nueve millones de pesos, suponiendo costos de administración que se encumbraran cerca de los dos millones de pesos ${ }^{69}$.

En el proyecto presentado por Victorino Rojas Magallanes, por otro lado, se incluía el impuesto a los viñedos, que a partir de las tres hectáreas de extensión deberían pagar un impuesto de diez pesos cada semestre: iniciativa aislada que solo en la última parte de nuestra etapa de estudio encontraría algún eco en la legislación. Por otro lado, los alcoholes importados pagarían una sobretasa de 19 centavos por litro, y los destilados partirían de la base de 15 centavos por litro de alcohol de $15^{\circ}$, subiendo un centavo por cada grado más de concentración alcohólica ${ }^{70}$.

Al momento de justificar la aplicación de un impuesto sobre las bebidas alcohólicas, las razones que esgrimió Benjamín Dávila Larraín en su memoria ante el Ministerio de Hacienda son interesantes de rescatar aquí, en tanto preveían con claridad el desarrollo posterior del tema impositivo en Chile. De acuerdo a este autor, la oportunidad que representaba la aplicación de un impuesto sobre los alcoholes debía de aprovecharse para modificar la estructura completa de los ingresos fiscales del país, en tanto que hasta ese momento se dependía en un $40 \%$-cifra que no dejaría de aumentar- ${ }^{71}$ de la exportación del salitre, y gran parte del resto de las entradas fiscales eran adjudicadas a través de las aduanas, y no de la riqueza interior. Por el contrario, la carga impositiva sobre el tabaco y el alcohol era indiscutible, dado que nadie podría argumentar que fuesen productos necesarios para el bienestar de la población. Puesto a realizar cálculos, el autor establecía que con un gravamen de cincuenta centavos por cada litro de alcohol puro, se lograrían recaudar casi quince millones de pesos, con gastos de administración no superiores a los doscientos mil pesos. En la práctica, el litro de aguardiente, en estas condiciones impositivas, aumentaría su costo final en apenas veinte centavos por litro. El objetivo del impuesto, asimismo, debía concentrarse en la abolición de las

69 Ricardo Dávila Boza, "La cuestión alcohólica en Chile", Memoria presentada al concurso abierto por el Supremo Gobierno sobre este tema en 1897, en $R C h H$, tomo V, 1899, 74-145.

70 Victorino Rojas Magallanes, El Alcoholismo y el impuesto sobre los alcoholes. Conferencia dada en el Centro Industrial y Agrícola de Santiago el 7 de agosto de 1898. Establecimiento poligráfico Roma, 1898, 19-25.

71 Esta afirmación puede verificarse al consultar las cifras de participación del salitre en los ingresos fiscales, que porcentualmente -es decir, independiente de su valor monetario- para 1897 han sido calculadas en más del 55\% del total, cifra que al año siguiente alcanzaría un techo de $67.73 \%$. Para las primeras décadas del siglo XX -con anterioridad a la aplicación del Impuesto sobre la Rentala cifra no bajó, sino excepcionalmente, del $40 \%$. Como promedio general entre 1880 y 1929 , se establece un porcentaje de participación de la industria salitrera en la tributación fiscal de $42.82 \%$. Roberto Hernández C. El Salitre. Resumen histórico desde su descubrimiento y explotación. Asociación de Productores de Salitre de Chile, Fisher Hnos., Valparaíso, 1930. 
pequeñas destiladoras agrícolas y la concentración de tales funciones en grandes y modernos establecimientos, más fáciles de fiscalizar y productores de alcohol de buena calidad. Por lo mismo, el autor consideraba que el impuesto a los destilados activaría la producción de vinos, gracias a lo cual las destilerías pequeñas abandonarían la destilación agrícola, concentrándose solo en la producción de vinos. Establecido de esta forma el impuesto, Dávila Larraín agregaba que los alcoholes importados deberían pagar, a lo menos, el doble de lo cancelado por la producción nacional, y que los montos recaudados por multas debidas a contravenciones de la ley, debían de entregarse para la formación y sostenimiento de asilos para enajenados, así en Santiago como en Concepción ${ }^{72}$.

De forma similar, Eliodoro Yáñez defendió la necesidad del impuesto por sobre el monopolio, en tanto consideraba a este último como “...una idea antipática, que en el común concepto de la gente, significa un ataque a la libertad, el abatimiento de toda iniciativa, la violación de un derecho, el abuso consagrado en forma oficial". Sin embargo, algunos monopolios debían de existir, como el representado por las oficinas postales y los ferrocarriles, que solo en manos del Estado lograban cumplir sus objetivos de servicio de alcance nacional. Pero para el caso del alcohol, no era justificada una medida de concentración de propiedad que era comprensible solo en casos excepcionales. Además, los defensores del monopolio -“...apóstoles que viven en un mundo imaginario y que jamás se colocan bajo el punto de vista contingente de la situación real del país"- debían saber que en casos concretos de su aplicación, como Suiza, el Estado recaudaba menos dinero con esta opción que con el impuesto. Junto a ello, esta alternativa monopólica pondría en tensión dos funciones centrales del Estado: el Estado mercader, interesado en la obtención de recursos para sus tareas, y el Estado higienista, concentrado en el bienestar de la población y su salud. Con el monopolio no sería raro, de acuerdo con Yáñez, el predominio del primero, poco útil para el combate al alcoholismo. Además, el monopolio exigiría enormes costos de indemnización, administración y el permanente riesgo del favoritismo y la corrupción estatal. Por tales motivos, la alternativa correcta estaba representada por el impuesto, que se iniciaría con un recargo de quince centavos por litro, cualquiera que fuese su graduación, medidos a través de contadores automáticos. Es decir, un monto muy pequeño, que el autor justificaba en su brevedad por la distancia de los centros de producción y los mercados y la obligación no de generar una renta fiscal cuantiosa, sino disminuir el consumo habitual. Junto a ello, y para no dañar a las destilerías industriales de forma irreversible, proponía la entrega de primas a la exportación, consistentes en la devolución del impuesto pagado en caso de salir el alcohol producido del mercado nacional ${ }^{73}$.

72 Benjamín Dávila L., op. cit. 108-117. Para este autor, las desventajas del monopolio, y más allá, de la participación económica del Estado, eran axiomáticas, en tanto “...este compra mal, trabaja con poca economía i vende con escaso acierto i que un negocio que en manos de particulares es fuente de considerables utilidades, en manos de un Gobierno suele ser solo origen de peligrosa corrupción". 127.

73 Eliodoro Yáñez, "La cuestión de los alcoholes", op. cit. 43-63. 
Finalmente, prevaleció la opción de la aplicación de un impuesto sobre las bebidas alcohólicas destiladas, y ello motivó debates parlamentarios que tuvieron uno de sus ejes en el estatuto que en tal sistema tendrían los alcoholes de destilación agrícola, en relación a los industriales, de menor costo de producción y no vinculados a la poderosa vitivinicultura nacional. En este debate se perfilaron claramente los intereses de los productores agrícolas, que a través del diputado conservador Gonzalo Urrejola Unzueta estimaron injusto e inequitativo que se gravara sus productos de baja concentración alcohólica -aguardientes entre $21^{\circ}$ y $30^{\circ}$ - de igual forma que los alcoholes destilados de más de $40^{\circ} 74$. A ello respondió Eliodoro Yáñez indicando que lo que los destiladores agrícolas buscaban era “...conservar el privilegio de destilar libremente, sin exigencias higiénicas ni control administrativo, los residuos de la uva o las materias primas provenientes de sus propios fundos"75. Del mismo modo, se discutió en la sala el destino que debía darse a los recursos obtenidos por medio del gravamen, que no pocos diputados consideraron debía dedicarse de forma exclusiva a la renovación del material bélico de la Marina nacional. De tal opinión fueron el liberal Gonzalo Bulnes Pinto, el conservador Francisco Rivas Vicuña y el mismo Eliodoro Yáñez, quien expresó: “...la acepto con tanto mayor gusto cuanto que ella tiende a hacer que, de lo que es una desgracia del país, se saquen elementos para aumentar la fuerza de la nación"76. Terminada la discusión en la Cámara de Diputados, el proyecto de ley que llegó al Senado estableció un impuesto de quince centavos por litro de $100^{\circ}$ para el alcohol agrícola y veinticinco para el industrial, que deberían aumentarse cada año cinco centavos, hasta llegar a cuarenta y sesenta centavos, respectivamente ${ }^{77}$.

Una vez en la Cámara de Senadores, el proyecto en cuestión fue sometido a una Comisión Especial, en el informe de la cual se estableció considerar como obligadas a pagar el impuesto a todas las bebidas alcohólicas de más de $16^{\circ}$-y no de $21^{\circ}$ como el proyecto anterior-, así como instaurar la determinación de los montos a pagar de parte de los destiladores agrícolas en función de un rendimiento calculado por hectárea y no por producción efectiva, como las destilerías industriales ${ }^{78}$. Sin embargo, la medida que volvió a despertar mayores diferencias fue el monto a pagar por los productores agrícolas, e incluso si estos debían o no pagar algún tipo de gravamen. Por ejemplo, el senador conservador Joaquín Walker Martínez consideró factible aumentar los montos de los alcoholes industriales, y no así a los agrícolas. Para el senador por Aconcagua y liberal demócratico Ignacio Silva Ureta, a los alcoholes agrícolas no debía de aplicárseles ningún gravamen, en tanto ya

74 BSECD, 1900, sesión $41^{\text {a }}$ en 11 de enero de $1901,923-924$

75 Ibibem.

76 BSOCD, 1901, sesión 48ª en 23 de agosto de 1901, 608-609. Algunos años más tarde, un autor explicaría el momento en que se aprobó la ley indicando: “...las grandes dificultades que nuestra Cancillería estaba empeñada en resolver apresuraron inopinadamente el aborto legislativo bautizado con el nombre de lei de alcoholes". Samuel Radrigán A., El alcoholismo $i$ la lei sobre alcoholes, Memoria de Prueba para optar al grado de Licenciado en la Facultad de Leyes y Ciencias Políticas. Santiago de Chile, Imprenta Cervantes, 1904, 15.

77 BSOCD, 1901, sesión $65^{\text {a }}$ en 6 de septiembre de 1901, 897-899.

78 BSES, 1901-1902, sesión 34ª en 11 de diciembre de 1901, 722-726. 
pagaban contribuciones territoriales, y sus costos, riesgos y plazos de retorno de la inversión eran mucho mayores que los de las destilerías industriales. Ante ello, el senador liberal doctrinario por Valdivia Eduardo Matte Pérez argumentó a favor de la igualdad del impuesto para destilados agrícolas e industriales, en tanto que el aumento del precio efectivo de las bebidas alcohólicas de alta graduación estimularía el consumo de bebidas sustitutivas, como el vino, la chicha y la cerveza, lo cual redundaría en una protección efectiva de la vitivinicultura chilena ${ }^{79}$.

Finalmente, y franqueando por un tiempo este tipo de diferencias, en enero de 1902 se promulgó la Ley № 1.515 , que contenía una legislación impositiva de nuevo cuño en Chile, consistente en lo fundamental en: la creación de un registro nacional de fabricantes, comerciantes por mayor e importadores de bebidas alcohólicas y alcoholes, bajo tutela de la Administración del Impuesto sobre los Alcoholes; la aplicación de un impuesto a toda bebida que contuviese alcohol en un grado mínimo de $16^{\circ}$ de acuerdo al alcohómetro de Gay-Lussac; el pago por parte de los destiladores industriales de alcohol de un impuesto de cincuenta centavos por cada litro de $100^{\circ}$, monto que subiría diez centavos cada año hasta llegar a un peso por litro; el pago de parte de las destilerías agrícolas de cuarenta centavos por litro de $100^{\circ}$ destilado de los residuos de la fabricación de vino, y de treinta centavos por litro de $100^{\circ}$ proveniente de la destilación de vinos, chichas o piquetas de lavado de orujos. Todos estos montos aumentarían anualmente diez centavos, hasta llegar a un peso por litro de $100^{\circ}$; el alcohol desnaturalizado, es decir, destinado solo al uso industrial, pagaría solo cinco centavos por litro; la medición de las cantidades producidas sujetas a contribución se establecería por medio de contadores mecánicos continuos en el caso de las destilerías industriales, en tanto que los destiladores agrícolas cancelarían un monto fijo, determinado por el rendimiento supuesto de cada hectárea sembrada con viñedos, de acuerdo a las condiciones de las distintas zonas productoras del país ${ }^{80}$.

Como conclusión del largo debate entre impuesto y monopolio, así como de los montos y formas de cobro del nuevo gravamen, se estableció por primera vez en el país un organismo de control y fiscalización impositiva, la Administración del Impuesto sobre los Alcoholes, que a la larga se transformaría en la Dirección General de Impuestos Internos y nuestro actual Servicio de Impuestos Internos. Junto a ello, se mantuvieron condiciones de privilegio para la destilación agrícola en relación a las destilerías industriales, y se eximió de todo pago a aquellas bebidas con una base alcohólica inferior a los $16^{\circ}$. Asimismo, no se estipuló un destino preciso para los dineros recaudados, que en todo caso no estarían en manos de los municipios, sino que de las arcas del Estado. Es decir, la propuesta de encarecimiento del consumo de bebidas alcohólicas se limitó a las de mayor poder alcohólico, manteniendo al vino -la más común de las bebidas embriagantes- libre de contribuciones, así como a los alcoholes de origen agrícola sometidos al pago

79 Ibid., 836-839.

80 Lei sobre alcoholes promulgada en el Diario Oficial de 16 de enero de 1902, op. cit. 4-5; 9-10 у 15 . 
de un monto de acuerdo a producción supuesta antes que efectiva. Como no es difícil sospechar, estos elementos de protección a la vitivinicultura en relación a las destilerías industriales causarían enconados debates a lo largo del periodo posterior a la promulgación de la ley de 1902, que dejarían de manifiesto la influencia en el Parlamento de los productores de vinos y alcoholes agrícolas en detrimento de los destiladores industriales.

Sin embargo, y antes de pasar al análisis de su concreta aplicación y transformación, es importante destacar aquí que la discusión generada, así en el Parlamento como entre los estudiosos del tema, desde la medicina, la economía y las políticas públicas, puso de manifiesto las diferencias que en el país existían en torno a los ámbitos de influencia en la vida económica que se podían adjudicar al Estado: con el rechazo al monopolio se buscó atemperar lo más posible esta intervención, por temor de la clase política y los sectores ilustrados a la utilización de tan formidable aparato administrativo fiscal en función de intereses partidistas. Como alternativa, la Administración del Impuesto nació como un organismo pequeño y con escaso presupuesto, en relación a las tareas que le establecía la misma ley. Del mismo modo, la intervención sobre la autonomía de los productores fue realmente muy escasa, reservándose el Estado la facultad de la fiscalización de la calidad de lo producido antes que su cantidad. Al mismo tiempo que se reprimía con dureza y de forma masiva la ebriedad pública, y que se buscaba una reglamentación rigurosa de los expendios al por menor, la esfera de la producción de bebidas alcohólicas no sufrió grandes modificaciones o restricciones de envergadura. Por el contrario, la legislación consideró concentrar el poder inhibitorio del consumo de bebidas alcohólicas de alta graduación en el costo final que el consumidor, no el productor, pagaban. De esa forma, quien pagaba efectivamente la contribución era el consumidor, por medio del alza de precios que el producto final, al momento de ser expendido, contenía. Así, junto con incentivar el consumo de bebidas alcohólicas fermentadas, el Fisco centró sus objetivos de tributación en los consumidores, no en los productores o intermediarios. ¿Era este esquema sustentable, y más aún, efectivo en el doble objetivo de disminuir las tasas de consumo inmoderado y dar al Estado una renta permanente y cuantiosa? Es lo que el análisis de su aplicación efectiva, sus reformas y sus críticas nos permitirá averiguar.

\section{APLICACIÓN, RENDIMIENTO, REFORMA Y CRÍTICA: LA LEGISLACIÓN IMPOSITIVA SOBRE LAS BEBIDAS ALCOHÓLICAS HASTA 1929.}

Con evidentes desequilibrios formales, la legislación antialcohólica nacía, en el sentido de las cargas impositivas que estableció, preñada con los elementos y vacíos que justificarían su reforma y complementación. Un tratamiento diferencial entre los alcoholes de origen industrial y agrícola, así como la ausencia de un gravamen específico para las bebidas fermentadas, fueron los elementos que motivaron las primeras críticas. A poco de ser promulgada la ley, su comentario por parte de distintos actores fue la norma, y nadie, ni sus más decididos promotores en el Parlamento, se manifestó satisfecho con el resultado final. Por ello, el proce- 
so de reforma de la ley se inició el mismo año de su puesta en práctica, siguiendo un camino que buscaba incorporar a los vinos y cervezas al esquema impositivo formulado. En este largo proceso, que seguiremos hasta fines de la década de 1920, se pusieron de manifiesto, por distintos medios, los intereses involucrados en la primera legislación tributaria chilena que se aplicaba a las bebidas embriagantes. Del mismo modo, la tensión existente entre los distintos objetivos de la ley -la represión del consumo inmoderado y la adquisición de una renta fiscal para el Estado- fueron motivo de críticas, dada la evidente contradicción que cada uno de estos mandatos legislativos implicaba. Por último, el rendimiento concreto del impuesto establecido fue menor al esperado, así como la capacidad funcionaria de la Administración del Impuesto sobre los Alcoholes se vio rápidamente sobrepasada por las condiciones de fiscalización que las características de la industria imponían. Todo lo anterior hizo urgente la reforma, y los contemporáneos, una y otra vez, así lo hicieron notar.

Los más afectados por la aplicación del cuerpo legislativo de 1902 fueron, claramente, los industriales del sur del país dedicados a la destilación de alcohol de granos: desde Osorno llegaban las primeras críticas, ese mismo año, ante lo que fue considerada una ley “...dictada con precipitación, casi sin debate”, que representaba para su actividad un "...eslabón de acero con que se coartan muchas libertades en homenaje a una política preventiva, que tiene grandes peligros"81. El núcleo de la ley se había detenido, de acuerdo al mismo autor, tan solo en el objetivo de aniquilar la competencia que el alcohol industrial hacía a las bebidas fermentadas, y no así en el análisis y la represión del impacto de estas en la alcoholización de los sectores populares. Junto a ello, extrañaba una observación más atenta de las características de las industrias destiladoras y su profunda relación con las provincias del extremo sur del territorio y las perturbaciones que la aplicación del impuesto generaría en estas ${ }^{82}$.

Con respecto a la aplicación de la normativa, consideraba que la creación de una nueva repartición pública solo conllevaría gastos que quizás no se limitarían a los propios recursos recaudados, y más allá, se experimentaría una verdadera anarquía, al enfrentarse las atribuciones de los fiscalizadores de la Administración de Impuesto, las facultades de los municipios otorgadas por la ley de Comuna Autónoma y los principios constitucionales de libertad de industria y de comercio ${ }^{83}$. Por todo lo anterior, "...la precipitación propia del interés ciego ha esterilizado los efectos de la lei del 18 de enero; la ha hecho nacer muerta". En virtud al equilibrio de intereses, el autor proponía que esta fuera tomada como un primer ejercicio, como una lección que obligaba, tanto a equilibrar las obligaciones de cada una de las industrias involucradas, como a tratar de forma independiente en nuevas iniciativas legislativas temas tan diversos como el impuesto, la prisión por ebriedad, la educación antialcohólica y los asilos para bebedores. Mientras ello no sucediera, se

\footnotetext{
81 J. Modesto I. de M. op. cit., 7.

82 Ibid. 14.

83 Ibid. 25-27.
} 
perderían de vista el desarrollo económico y administrativo de Chile, y peor aún, se aboliría el respeto a la ley de parte de los ciudadanos honrados y comprometidos con el desenvolvimiento económico y social de sus territorios ${ }^{84}$.

Al mismo tiempo, un conjunto de 81 agricultores de los departamentos de La Unión y Osorno hacían llegar al Presidente de la República sus opiniones sobre la Ley $\mathrm{N}^{\circ} 1.515$, expresándole, junto a su apoyo a las normas de pureza y calidad de los alcoholes expedidos que la normativa exigía, la amenaza de muerte que esta significaba para sus industrias, por el alza de los costos y la dificultad de competir con el alcohol agrícola a causa de la diferencia establecida en la tributación a cada producto. Ante ello, solicitaban que dicha diferencia fuese anulada. Asimismo, pero esta vez 43 agricultores de La Unión, estimaban que la única medida posible de aplicar era la reducción en un 50\% del monto del impuesto establecido -igualando al mismo tiempo el gravamen al alcohol agrícola con el de origen industrial- con el fin de preservar la demanda sobre los productos agrícolas de la zona, que de otra forma no tendrían otra salida comercial que la representada por las destilerías industriales ${ }^{85}$.

Por su parte, los productores de vinos, sin mostrase en desacuerdo con el conjunto de la legislación, manifestaron su disconformidad con las atribuciones que poseía la Administración del Impuesto, en particular la facultad de perseguir como infractores y someter a la justicia a quienes produjeran alcoholes que no cumpliesen las condiciones de pureza que la ley establecía, poniendo de tal forma “...la fortuna, el honor i el bienestar de un sinnúmero de gente en manos de los empleados de la Administración de los Alcoholes, quienes se ha convertido por obra $\mathrm{i}$ gracia de la ley en químicos eximios...". Como solución ante el particular, proponían que el Estado comprase el alcohol de origen agrícola y lo rectificase en dependencias fiscales ${ }^{86}$. Es decir, se quejaban por la capacidad de las instituciones públicas de someter a un tipo de control higiénico a sus productos, al mismo tiempo que pedían la instalación de un monopolio estatal que asegurase un mercado para los alcoholes de origen agrícola: tras cerca de siete años de discusión parlamentaria, la opción monopolista seguía pareciendo eficiente para algunos de los actores involucrados, siempre desde la perspectiva de obtener el mayor de los beneficios. Ante la situación por la que pasaba la industria destiladora, en todo caso, un organismo relacionado con los productores de vinos y alcoholes agrícolas como era la SNA, se limitó a recomendar que siguieran el ejemplo del Perú, donde se realizaba la feria de la utilización industrial del alcohol ${ }^{87}$.

84 Ibid., 33

85 Presentaciones hechas al Soberano Congreso y a su excelencia el Presidente de la República por los agricultores de los Departamentos de la Unión y Osorno tocantes a la Reforma de la Ley de Alcoholes, Santiago de Chile, Imprenta y encuadernación "El Globo", 1902, 7-13.

86 Estudio de la ley que reglamenta la producción y expendio de Alcoholes y Bebidas Fermentadas presentado por el Consejo de la Sociedad Nacional de Viticultores al Supremo Gobierno, Santiago de Chile, Imprenta, litografía y encuadernación Barcelona, 1902, 14, 23-24.

87 BSNA, Vol. XXXIV, $\mathrm{N}^{\circ} 12$, marzo de 1903, 189-191. 
Los destiladores industriales no se demoraron en responder tanto a los viticultores como al Gobierno, ante el impacto que la nueva ley estaba provocando en sus actividades: considerando que la ley había sido discutida de forma apresurada y sin los conocimientos técnicos indispensables, producto de la urgente necesidad de recursos ante situaciones internacionales que amenazaban la tranquilidad nacional, estimaban necesario tanto el incentivo al uso industrial del alcohol, como el reconocimiento de que el producto de origen agrícola era incomparablemente más impuro debido a su primitiva destilación. Sin embargo, e independiente de cuál era el más puro o el más tóxico de los alcoholes producidos, el Sindicato de Destiladores Industriales de Chile aducía como queja de fondo el hecho de que se había promulgado, a poco de publicada la ley, el Decreto 890, que establecía que el rendimiento por hectárea de viñedo serviría para determinar el pago de contribuciones de parte de los productores agrícolas de alcohol. Esto significaba, en la práctica -según esta asociación-, que el alcohol agrícola pagaría cerca de una duodécima parte de lo que de acuerdo a la ley debía pagar -30 centavos por litro de $100^{\circ}-$, puesto que los rendimientos eran mucho mayores que los expresados en ese decreto. Aducían asimismo que se privilegiaba la elaboración de aguardientes de hasta cincuenta grados, por lo que cada litro producido pagaba menos que el industrial, que estaba elevado a los $100^{\circ}$. Por lo tanto, exigían la equidad en el impuesto, que este no se alzase como lo ordenaba la ley por lo menos en los dos siguientes años y el fin del cálculo por rendimiento, debiendo el alcohol agrícola pagar también de acuerdo a producción efectiva. En caso de no producirse esta modificación, la industria se paralizaría, y ello no significaría "...la disminución del consumo, pero sí el detrimento de los intereses fiscales" 88 .

Coincidiendo con lo anterior, la Sociedad Nacional de Agricultura expresaba a través de su publicación -tradicionalmente ligada a los intereses de la vitivinicultura y los destiladores agrícolas- que "... aquello no era en realidad un impuesto, era una prohibición casi terminante, una orden de clausura, era la muerte inevitable de las industrias de destilación"89. Y algo después establecía, como única forma de resolver el desequilibrio reinante en la producción de alcohol, que todo alambique, por primitivo que fuese y usase la materia prima que usase, tuviese un contador mecánico que informara de su producción efectiva ${ }^{90}$.

Como manifestación clara de este tipo de desajustes de la ley, podemos citar los primeros datos con respecto al rendimiento efectivo del impuesto sobre los alcoholes, así como una evaluación de conjunto de su aplicación, presentados en la Primera memoria de la Administración del Impuesto sobre los Alcoholes, redactada por su director el ingeniero Julio Cousin Daumiere, y expuesta ante el Ministerio de Hacienda. Allí se establecía que, en los primeros catorce meses de

\footnotetext{
88 Sindicato de Destiladores Industriales de Chile. Apreciaciones sobre la reforma de la ley de alcoholes a propósito de la última publicación de la Liga Vinícola, Santiago de Chile, imprenta y encuadernación "El Globo", 1902, passim. Las cursivas en el original.

89 BSNA, Vol. XXXV, $\mathrm{N}^{\circ} 15$, abril de 1904, 221-224

$90 \quad$ Idem, $\mathrm{N}^{\circ} 17$, abril de 1904, 253-256.
} 
aplicación de la Ley $\mathrm{N}^{\circ} 1.515$, se habían obtenido poco más de 1.275.000 pesos, de los cuales solo 400.000 pesos correspondían a tributos pagados por alcoholes agrícolas. Junto a ello, comentaba que la falta de claridad en torno a las disposiciones de la ley y "la mala fe de algunos destiladores o comerciantes sometidos a dicho régimen, han originado numerosas contiendas judiciales", muchas de las cuales habían quedado sin sanción. Como efecto inmediato, además, se anotaba el fin de la mayor parte de las fábricas de vinos artificiales -que tenían en el alcohol industrial su principal, y antes barata, materia prima-, y por ello, que el precio del vino natural se hubiese doblado, al igual que los licores producidos con el fruto de las destilerías industriales.

Sin embargo, y he aquí el principal problema denunciado por el funcionario de la Administración, el aumento del costo del alcohol industrial no había sido acompañado del mismo comportamiento de parte de aquel de origen agrícola, y muy por el contrario, al pagar este menos contribución, competía de forma inequitativa con los productos industriales, que detenían su producción, pagaban más impuestos e iban directo a la quiebra, mientras que los destiladores agrícolas obtenían mejores precios -siempre menores que los industriales- y enormes ganancias. Junto a ello, lo reducido de la recaudación se debía a que, al no estar las bebidas fermentadas gravadas, el público consumidor se dirigía a ellas en busca de la ebriedad, apartándose del consumo de los productos sujetos a tributación. En palabras de Cousin, “...el vicio tiene, pues, siempre su válvula de escape, su refugio, en el empleo de las bebidas fermentadas a bajo precio. La ley económica de la sustitución se cumple fatalmente" 91 .

Tras dar cuenta del estado de la Administración, el funcionario relevaba las necesidades de reforma que consideraba necesarias de iniciar: dividir al país en zonas de inspección agrícola más detalladas, con distintos rendimientos por hectárea representativos de la realidad de cada localidad. Con respecto a lo mismo, era consciente de la necesidad de acabar con las millares de pequeñas destilerías agrícolas, por medio de la construcción -a mediano plazo- de grandes establecimientos estatales, en el corazón de las zonas de producción agrícola. Es decir, no modificar el fondo del régimen existente, sino solo perfeccionarlo en ese punto, con el objeto de obtener una renta más cuantiosa gracias a la efectiva tributación del alcohol agrícola. Junto a ello, estima acertada la falta de impuesto a las bebidas fermentadas, como forma de protección a la industria vitivinícola. Del mismo modo, mantuvo su opinión de que el impuesto era la mejor forma de encarecer el consumo de alcoholes, y a través de su recaudación, solventar los gastos que los mismos bebedores inmoderados causaban al erario ${ }^{92}$.

Ya en su segunda Memoria, publicada el año 1906 y con un plazo algo mayor de evaluación, el administrador del Impuesto explicaba que las consecuencias de la aplicación del tributo sobre las destilerías industriales y agrícolas había sido en

91 Primera Memoria del Administrador del Impuesto sobre Alcoholes presentada al Ministerio de Hacienda, op . cit., 90-91, 96, 99, 124-125.

92 Ibid., 200-204. 
efecto contundente: las primeras habían disminuido de 30 a solo seis, y las segundas, de cerca de ocho mil a no más de seis mil. Sin embargo, ello despertada la preocupación del funcionario, en tanto el encarecimiento del valor del alcohol estaba destruyendo industrias de importancia regional -en particular en el extremo sur-, dado que sus producciones no estaban siendo dirigidas hacia una utilización alternativa. Y al mismo tiempo, la diferencia en los criterios de cobro hacía del alcohol agrícola un producto barato, por lo que las tasas de consumo no disminuían, ni tampoco entraban al erario los montos correspondientes al volumen real de producción agrícola, debido al cobro por rendimiento supuesto ${ }^{93}$. Todo ello se traducía en la baja constante de la recaudación final que llegaba a manos del Fisco, que para 1904 se calculaba, entre alcoholes agrícolas e industriales, en poco más de $900.000^{94}$ pesos. Un año más tarde, en 1907, la Administración del Impuesto daba cuenta de las consecuencias económicas concretas que las medidas impositivas habían generado en el mercado chileno del alcohol: el precio había subido por la disminución de la oferta debida al cierre de destilerías y alambiques y al agotamiento de las reservas anteriores a la ley que habían mantenido un precio uniforme los primeros años. Ello había redundado en que las posibilidades de exportación -estimuladas en la propia ley por medio de las primas al comercio exterior- se redujesen, puesto que los productores consideraban más atractivo el mercado nacional, con demanda creciente y altos precios.

Es decir, el objetivo económico de la legislación, de promover la exportación de alcohol con el fin de no dañar a las industrias locales, no se cumplía, y las restricciones a estas habían tornado la fabricación de alcohol potable en una actividad aún más atrayente que antes. Asimismo, se mantenían las quejas sobre el método de cobro a los alcoholes agrícolas, que no pagaban más que el 50\% de lo que les correspondería en caso de medirse la producción efectiva, y amparaban una vasta producción clandestina, que el funcionario situaba en más del doble de la cantidad de aguardiente bajo efectiva fiscalización. Por último, se informaba que el rendimiento del impuesto había ascendido en 1905 a 1.650 .000 pesos, dos tercios de los cuales correspondían al alcohol de procedencia industrial ${ }^{95}$.

Este tipo de informes oficiales daban a la larga la razón a aquellos críticos de la ley que argumentaban tanto la aniquilación de las pequeñas y grandes destilerías, como a la inequidad del método de cobro diferenciado y la proporcional escasez de recursos efectivamente puestos a disposición del Estado gracias a la nueva contribución. Sin embargo, a ese tipo de crítica, que podríamos calificar de constructiva y técnica, se agregaron otras, que consideramos importante reseñar como forma de dar cuenta de las distintas perspectivas desde la cuales se enfrentaba el funcionamiento de una ley con estas características. En primer lugar, hemos podido recopilar un cuestionamiento que bien pudo representar el sentir de aquellos identificados

93 Segunda Memoria del Administrador del Impuesto sobre Alcoholes presentada al Ministerio de Hacienda, op. cit. pp. ii-iii.

94 Ibid., 56-61.

95 Tercera Memoria del Administrador del Impuesto sobre Alcoholes presentada al Ministerio de Hacienda, Santiago de Chile, Imprenta, Litografía y Encuadernación Barcelona, 1907, 90-95. 
con el rechazo a la intervención del Estado en ámbitos que consideraban propios de la iniciativa privada. Como ejemplo de ello podemos citar el caso de una memoria de leyes de 1904, que consideraba desde un principio a la ley de alcoholes como una derrota de los "individualistas, los más valientes impugnadores de la intromisión de los poderes públicos", ante "sus adversarios, los estatólatras". Dicho esto, argumentaba, apoyándose en Zorobabel Rodríguez, que el único efecto del impuesto sobre los alcoholes había sido obligar al consumidor -y en particular a los más pobres- a dedicar una parte aún mayor de sus salarios a la satisfacción de su vicio, así como a ingerir brebajes más tóxicos y adulterados que los que consumían antes de la aplicación del gravamen. A su juicio, el impuesto no era más que un recurso económico del Estado para, bajo el manto de políticas de higiene, "cubrir en realidad los déficits del tesoro público, i ocultar los derroches injustificados de los dineros fiscales". A la larga, y a pesar de ser promovido como una alternativa de financiamiento ante un posible enfrentamiento militar con Argentina, no había riqueza alguna en manos del Estado, y por el contrario, “...las arcas fiscales vaciadas por los gastos del nuevo servicio; el alcoholismo en su apogeo, i como resultado final, la única industria floreciente antes de la vigencia de la lei, arruinada". Por todo ello, lo que el autor proponía era la protección efectiva de la industria de la destilería, la modernización de la destilería agrícola por medio de la entrega de alambiques más eficientes, la moderación de los impuestos asignados y la entrega a sociedades de temperancia y beneficencia de los recursos así obtenidos para iniciar la enseñanza antialcohólica, único método que podría dar resultados ciertos contra el inmoderado beber ${ }^{96}$.

Tampoco faltaron defensores de los pequeños destiladores agrícolas, que percibieron que la obligación de declarar su condición de destiladores, aun cuando lo hicieran en mínimas cantidades y con el solo objeto del consumo familiar, era un deber oneroso, que en caso de no cumplir los exponía a juicios contra la Administración del Impuesto, cuyos costos estaban impedidos de pagar. A nombre de los pequeños destiladores agrícolas de Peumo se pronunció el presbítero Ricardo Mesa, quien consideraba que por este método "...se repletaban las arcas fiscales con quitar a los pobres lo que es suyo"97. A más abundamiento, en la misma publicación se incluía un artículo de prensa, publicado en El Mercurio a fines de marzo de 1904, en donde se alegaba sobre la pésima situación, producto de la ley, tanto de las grandes destilerías de Valdivia como de los ínfimos destiladores agrícolas del resto del país, la que se atribuía así a la cuantía del impuesto como a que “...no todos los empleados de la Administración proceden correctamente en el desempeño de sus funciones, y el desinterés con que la Administración recibe las consultas razonadas y discretas de los interesados, se acabara de comprender y justificar la mala voluntad, la antipatía, el horror con que los agricultores miran la ley..." 98 .

96 Samuel Radrigán A., op. cit., 6-11, 15-21.

97 Luis Alberto Mesa T., La Ley sobre alcoholes y los pequeños propietarios, Santiago de Chile, Imprenta, litografía y encuadernación Chile, 1904, 5-10.

98 Ibid., 17-18. 
Como consecuencia de las comentadas falencias de ley, así como por los conflictos de intereses que su aplicación puso de manifiesto, el proceso de reforma al cuerpo legal se inició el mes de junio de 1903, con un proyecto que incluía algunas las ideas expuestas en la Memoria antes citada, y firmado por Julio Cousin -administrador del impuesto a los alcoholes-, Carlos Fernández Peña - reputado médico higienista- y Eliodoro Yáñez, como parlamentario de las provincias destiladoras del sur del país ${ }^{99}$. En el Mensaje Presidencial que daba inicio al largo proceso legislativo -concluido solo en 1916-, se anotaban como principales áreas requeridas de revisión las atribuciones y número de los funcionarios de la Administración del Impuesto, una mayor coordinación entre estos y los agentes productivos involucrados en la industria de las bebidas embriagantes, el fin del aumento anual del impuesto en diez centavos cada año y el establecimiento de procedimientos judiciales más expeditos en los casos de violación de las disposiciones de la ley ${ }^{100}$. El proyecto de ley presentado pasó a ser estudiado por la Comisión de Industria de la Cámara, presidida por el defensor de los intereses agrícolas, el conservador Gonzalo Urrejola, y en su informe estableció la necesidad de reforma de la ley de 1902 -caracterizada como "simple ensayo-, y fijar el impuesto sobre los alcoholes industriales en 50 ó 60 centavos el litro de $100^{\circ}$, y los agrícolas a veinte centavos por litro, independiente de su graduación ${ }^{101}$. Para muchos diputados era urgente llevar a cabo las reformas necesarias con prontitud, tanto para impedir que los industriales "continúen arruinándose", como para detener el alza anual del impuesto fijado en la ley, aun por medio de un artículo único que estableciera el congelamiento de los montos a cobrar ${ }^{102}$.

Puestos a criticar la ley vigente, los parlamentarios no ahorraron en argumentos: de acuerdo con el diputado liberal doctrinario por Valdivia y La Unión, Carlos Zañartu Fierro, la ley no había cumplido con sus objetivos ni de castigar la embriaguez de forma efectiva, ni de proporcionar recursos a las escuelas para implementar programas de educación antialcohólica. Por el contrario, lo único que había logrado en su breve vida había sido "...destruir una industria próspera desde hace más de 30 años, que tiene invertidos más de catorce millones de pesos en maquinarias y establecimientos" 103 . Con cifras en la mano, el senador liberal y médico Federico Puga Borne explicaba que los costos de la administración del impuesto y la entrega de primas de exportación a los productores habían generado solo pérdidas para el Estado, que calculaba en cerca de 250.000 pesos cada año, y que no dejarían de aumentar ${ }^{104}$. Por lo mismo, el diputado liberal democrático por Osorno

99 Primera Memoria del Administrador del Impuesto sobre Alcoholes presentada al Ministerio de Hacienda, op. cit., 197.

100 BSOCD, 1903, sesión 29a en 16 de junio de 1903, 630-631.

101 BSECD, sesión 20ª en 21 de noviembre de 1903, 375-376.

102 Idem., sesión $45^{\text {a }}$ en 28 de diciembre de 1903, 983; sesión $60^{\circ}$ en 19 de enero de 1904, 1225.

103 Idem., sesión 64 a en 22 de enero de 1904, 1325.

104 Idem., sesión $65^{\text {a en }} 23$ de enero de 1904, 1334. 
Efraín Vásquez Guarda proponía la abrogación inmediata de la ley, hasta que la reforma de la misma estableciese un régimen que no fuera tan dañoso con las industrias de su representación ${ }^{105}$.

Por todo lo anterior, y en un segundo Mensaje Presidencial, Germán Riesco reconocía que la aplicación del tributo “...no produce resultados apreciables para el Erario i, en cambio, perturba anualmente la industria i el comercio del ramo con la alteración de precios", por lo que recomendaba detener el aumento de los cobros hasta el año de $1906^{106}$. De todas formas, y por medio de decretos, el valor de la tributación por litro quedó congelado en 70 centavos en 1905, lo cual, junto con la obligación también decretada de instalar contadores automáticos en los alambiques que destilasen alcohol agrícola ajeno, provocaba, de acuerdo con el diputado conservador Gonzalo Urrejola, la desaparición de la pequeña industria agrícola de destilación ${ }^{107}$. De esa forma, y por medio de decretos emanados desde el Ministerio de Hacienda, la situación de los alcoholes se mantuvo en un límite que, junto con despertar las quejas de los productores agrícolas y disminuir la cantidad de industriales dedicados al negocio, permitió un trámite más reposado de las reformas a la ley de 1902 que, como se podía augurar, debían ser de fondo, y a la larga derivarían en una nueva legislación.

Como parte de esta nueva etapa legislativa, el proyecto original pasó a manos de una Comisión Especial, la cual evacuó su informe a fines de 1910. En este informe, se indicaba con respecto al tema puntual de los impuestos que las destilerías agrícolas debían seguir pagando de acuerdo a un rendimiento supuesto por hectárea, pero alzando el monto de los pagos respectivos. Del mismo modo, se planteaba el alza al impuesto al alcohol desnaturalizado de uso industrial. Con tales reformas, se proponía aumentar la recaudación desde el millón y medio de pesos anuales obtenidos hasta esa fecha, a cerca de seis millones ${ }^{108}$. Sin embargo, los alcances de esta propuesta de reforma iban más allá de lo que a primera vista se puede observar: al aumentar el monto del impuesto pagado por cada hectárea de viñedo, se estaba apelando a la totalidad de las tierras sembradas con viñas, es decir, destilasen o no sus productos. Con ello se daba el primer paso para cobrar un gravamen a la producción de vino, tal y como lo interpretó el Centro Industrial y Agrícola que, en 1912, hizo llegar a la Cámara una solicitud indicando que el cobro de este tipo de tributo fuese aplicado solo a partir de los cinco años de sembradas para las viñas con regadío, y desde los siete u ocho para las de secano. Luego de ello, proponían que el cobro se aplicase durante veinte años, reduciéndose a partir de esa fecha el monto cobrado en $1 \%$ hasta que el agricultor decidiese arrancar sus viñas, y con el dinero ahorrado, cambiar el destino agrícola de su propiedad ${ }^{109}$. Es decir, al mismo tiempo que se señalaba el camino a través del cual se debía transitar para obtener recursos de

105 BSOCD, 1904, sesión 80a en 6 de septiembre de 1904, 1649.

106 BSECD, 1904-1905, sesión $76^{\mathrm{a}}$ en 17 de enero de $1905,1629$.

107 BSOCD , 1905, sesión 28 a en 11 de agosto de 1905, 721-723.

$108 B S E C D, 1910$, sesión $15^{\text {a }}$ en 28 de noviembre de $1910,434-440$.

109 BSOCD , 1912, sesión 39 en 9 de agosto de 1912, 1213-1216. Poco menos de un año antes, la SNA advertía que, en caso de aplicarse el sistema de cobros por rendimiento supuesto a las destilado- 
la industria vitivinícola, se proponían alternativas concretas de transformación de la misma, objetivo último que, como ya vimos más atrás, poco tiempo después sería presentado como ineludible por los movimientos antialcohólicos.

Siguiendo el paso pausado del debate parlamentario, y a la vez como ilustración de la importancia que la reforma de la ley tenía para el Ejecutivo, a inicios de mayo de 1914, y en la sesión de apertura de la legislatura extraordinaria de dicho año, el Presidente de la República, Ramón Barros Luco, expresaba en su Mensaje Presidencial la necesidad de aplicar nuevas imposiciones diferenciales a los distintos alcoholes, en tanto se había caído en la cuenta de que las industrias de refinación de azúcar y melazas estaban produciendo un alcohol aún más barato que el de la destilación de granos, por lo que debía someterse a las primeras a un gravamen comparativamente más alto. Junto a ello, insistió en aplicar un tributo a la producción efectiva del alcohol agrícola, por medio de la instalación de grandes destilatorios fiscales en las regiones vinícolas. Se proponía que el impuesto pagado por este tipo de alcohol fuera menor que el cobrado a los industriales. Como cargas impositivas novedosas, se buscaba gravar a las fábricas de licores con un impuesto especial, y a la producción de vinos, con un cálculo de rendimiento supuesto por hectárea.

De tal forma, los valores que se establecían eran los siguientes: para el alcohol de melazas y residuos de fabricación de azúcar: 1.20 pesos; para el alcohol de origen industrial, 1.0 pesos; para el de origen agrícola, 0.40 pesos, subiendo en diez centavos cada año hasta llegar a 0.80 pesos; para quien destilara alcohol agrícola de viñas ajenas a su propiedad, 0.30 pesos, subiendo también diez centavos cada año hasta llegar a 0.60 pesos; para las fábricas de licores, desde 0.40 pesos hasta 1.50 pesos, dependiendo los grados alcohólicos de cada bebida. La contribución de las hectáreas de viñedo sería, en relación a su rendimiento supuesto, desde Tacna hasta O'Higgins, de 40 pesos para las de regadío y 20 pesos para las de rulo; de Colchagua a Concepción, de 30 pesos para las primeras y 15 pesos para las segundas, y de Bío-Bío al sur, de 20 pesos y 10 pesos, respectivamente ${ }^{110}$. Algún tiempo después, el proyecto sería complementado por la Comisión de Hacienda de la Cámara, que agregó un impuesto a la cerveza -tres centavos por litro de menos de $4^{\circ}$ de alcohol y cinco centavos para aquellas de mayor graduación- y una baja en el impuesto al alcohol destilado proveniente de los vinos, con el fin de poner fin a la "crisis sin precedentes" que experimentaba la viticultura nacional ${ }^{111}$.

En conjunto, estas indicaciones eran las más detalladas y completas que hasta ese momento se habían propuesto en el plan de reforma de la ley de 1902, y evidentemente, implicaban un cambio de fondo en el esquema de tributación, tanto por contemplar nuevos objetos de gravamen, como por proponer formas de cobro y

\footnotetext{
ras agrícolas, ello representaría el tiro de gracia definitivo para las destilerías industriales, en tanto “...la mayoría de los vinicultores tratarán de producir el maximun de alcohol que la misma lei les autoriza, con el objeto de sacar en parte el valor del impuesto que están obligados a pagar. La producción de alcohol aumentará por consiguiente, su precio será relativamente bajo dado el excedente de alcohol que se van a producir, lo que permitirá que pase a ser de nuevo la bebida favorita del pueblo..." BSNA, Vol. XLII, N 9, septiembre de 1911, 577-579.

110 BSECD, 1914, sesión $1^{\text {a }}$ en 4 de mayo de 1914, 9-13.

111 BSECD, 1914-1915, sesión 50a en 16 de diciembre de 1914, 1162-1167.
} 
control de parte del Estado novedosas. Por la misma razón, la discusión parlamentaria en los siguientes meses se concentraría en cada una de estas diferencias y detalles, dejando en evidencia los distintos actores productivos que en la Cámara buscaban hacer valer sus intereses: claramente, con la baja del impuesto a la destilación de vinos se buscaba la protección de dicha actividad frente a los destiladores industriales. Al mismo tiempo se proponía el cobro de un tributo a la cerveza, bebida que por sus condiciones de menor poder embriagante hasta ese momento había sido excluida de cualquier imposición, pero que sin duda el aumento sostenido en su consumo -y por ello en su fabricación- hacía recomendable gravar, a despecho de los discursos que la indicaban como bebida higiénica y sustitutiva de alcoholes más poderosos ${ }^{112}$. Como expresara en su momento la Liga contra el Alcoholismo, la situación en la que quedaba el alcohol producido de la destilación de vino era de claro privilegio, y bajo el argumento de la protección a dicha industria, se olvidaba la necesidad de “...proteger a nuestro pueblo i a nuestra raza mucho más amenazados"113. Del mismo modo, un autor había considerado, algo antes, que la determinación de diferencias impositivas entre los distintos tipos de alcoholes era “...obra exclusiva de la oligarquía de viticultores. Científicamente está establecido que el alcohol sea de uva o de caña, cereales, madera, etc., es químicamente igual. No hay razón para atacar más a uno que al otro" 114 .

Finalmente, y a pesar de las opiniones en contra, la Cámara de Diputados aprobó el proyecto presentado por la Comisión de Hacienda, que incluía el polémico impuesto de solo cuarenta centavos al alcohol producido por destilación de vinos, pasando a consideración de los senadores el último día del año 1914. Semanas más tarde, a la misma corporación llegaba una nota de los fabricantes de alcohol industrial de Valdivia y Llanquihue, solicitando que el impuesto aplicado a los alcoholes por ellos elaborados y los agrícolas se igualara de una vez ${ }^{115}$. De similar opinión fue el senador conservador Joaquín Walker Martínez, opuesto a diferenciar las fuentes del alcohol al momento de gravarlos, así como al impuesto a la cerveza, en tanto que los montos propuestos en el proyecto aprobado por los diputados alcanzaban hasta un tercio de su valor final, por lo que, argüía, sucedería con la industria de la cerveza lo que había acontecido a principios de siglo con las

112 Al respecto, el diputado demócrata por Concepción Malaquías Concha expresaba: “...se nos presenta un proyecto de lei que tiende a que todo el vino del país se convierta en alcohol, o sea se trata de hacer más grave la situación obrera. Yo comprendería que si la cerveza le hiciera más daño al pueblo que el vino o el alcohol, se la gravara con un impuesto crecido si se quiere, pero me parece que no es así, que entre las bebidas alcohólicas ella es una de las más inofensivas. Sin embargo, esto se propone, porque la lógica se ha perdido ya en este país por completo. Es inútil buscarla aquí, por lo menos". BSECD, 1914-1915, sesión $13^{\text {a }}$ en 10 de noviembre de 1914, 363-366. En referencia a la industria de la cerveza durante el periodo anterior a la aplicación de la primera ley de alcoholes, de Juan Ricardo Coyoumdjian, "Una bebida moderna: la cerveza en Chile en el siglo XIX", en Historia $\mathrm{N}^{\circ} 37$, vol. II, julio-diciembre 2004, 311-336.

113 BSECD, 1914-1915, sesión 59a en 24 de diciembre de 1914, 1370-1371.

114 Fernando Sandoval Hurtado, Ensayo sobre la cuestión social en Chile, Memoria de prueba para optar al grado de Licenciado en la Facultad de Leyes y Ciencias Políticas, Santiago, Imprenta Bellavista, 1913, 21.

115 BSES, 1914. Documentos Parlamentarios, sesión 74ª en 16 de febrero de 1915, 607. 
destilerías del sur del país: su virtual desaparición ${ }^{116}$. Sobre lo mismo, el senador liberal Gonzalo Bulnes consideraba que si hasta ese momento no se había considerado un impuesto específico a la cerveza era porque esta debía ser, dada la ley de la sustitución de los productos alcohólicos gravados, “...el puente para destruir el alcoholismo; sin embargo, este proyecto tiende a eliminar este puente, porque coloca a la cerveza en situación desfavorable con respecto al vino"117. A pesar de estas diferencias, el proyecto fue aprobado en general, con la sola oposición de Walker Martínez, quien iniciaría su debate específico poco tiempo después. Y su argumento principal siguió siendo el fraude en que caían, de forma sistemática, las destilerías agrícolas, que por el rendimiento supuesto por hectárea producían en la realidad hasta diez veces más alcohol del que efectivamente pagaban contribución, razón última de por qué la recaudación se había estancado en los últimos años a poco más de dos millones y medio de pesos, de los cuales siempre la industria destiladora proporcionaba las dos terceras partes o más ${ }^{118}$. Por su parte, el más ardiente defensor de los alcoholes agrícolas y su estatuto de privilegio fue el ahora senador conservador Gonzalo Urrejola, quien, siendo él mismo destilador, mantuvo sus opiniones en torno a la justicia del impuesto diferenciado, motivando con ello altercados que concluirían con el envió del proyecto a una nueva Comisión, de la que participarían Urrejola, Walker Martínez, Arturo Alessandri y Eliodoro Yáñez, entre otros ${ }^{119}$.

En su informe, la Comisión determinó mantener las divisiones de tributo para cada uno de los alcoholes, de acuerdo a su origen: 1.40 pesos para el litro a $100^{\circ}$ proveniente de las melazas, 1.20 pesos para el industrial y 1.00 pesos para el agrícola o de vino. Para el desnaturalizado con destino industrial, diez centavos por litro de alcohol de $85^{\circ}$; para las fábricas de licores, solo la mitad de lo propuesto, pues ya pagaban el impuesto al comprar el alcohol a las destilerías. Sobre los vinos y chichas, se inclinaban a favor de la resolución de los diputados, es decir, impuesto por rendimiento supuesto de cada hectárea, estableciéndose dos grandes zonas vinícolas, que pagarían desde 30 pesos por hectárea de riego hasta 10 pesos por la de rulo. El gravamen a la cerveza se proponía en dos centavos por litro de hasta $4^{\circ}$ y tres centavos a las de mayor graduación. En un voto de minoría, presentado por Yáñez, se anotaba la eximición impositiva del alcohol de uso industrial, y un impuesto de tres centavos por litro - producción efectiva- al vino y la chicha ${ }^{120}$.

Es decir, toda la discusión volvía a girar en torno a la máxima de igual impuesto al mismo producto, independiente de sus fuentes, y la aprobación o rechazo a los nuevos objetos de tributación: vinos, chichas y cervezas. Acompañado de una solicitud de los destiladores de melazas, el senador radical por Concepción Daniel Feliu Manterola proponía la igualación de todos los montos a 1.40 pesos, o la

116 BSES, 1915. Debates, sesión $10^{\text {a }}$ en 2 de noviembre de $1915,157$.

117 BSES, 1915. Debates, sesión 30ª en 16 de diciembre de 1915, 507-508.

118 BSES, 1915. Debates, sesión 40a en 5 de enero de 1916, 773.

119 Ibid., 773-778.

120 BSES, 1915. Documentos Parlamentarios, 406-418. 
rebaja del aplicado a sus peticionarios a 1.20 pesos, opinión en la que era secundado por el representante nacional por Maule, Arturo Besa Navarro, que indicaba que las fábricas chilenas de azúcar -las destiladoras de melazas como subproducto- ya pagaban un impuesto por la importación de sus materias primas, por lo que el alza del gravamen solo favorecería a la importación de azúcar desde el extranjero ${ }^{121}$. El mismo Besa se opuso a la baja del tributo a los alcoholes de uso industrial, sospechosos a su juicio de ir a parar al final a las fábricas de licores, producto de la supuesta corrupción de algunos funcionarios de la Administración del Impuesto ${ }^{122}$. Finalmente, en este particular, esta argumentación se rechazaría y prevalecería el gravamen de diez centavos por litro ${ }^{123}$.

El que ese punto se despejara permitió que el debate se centrase en la propuesta de aplicación de un impuesto al vino, y su estricta relación con la misma medida aplicada a las cervezas: el senador conservador por Llanquihue Alfredo Barros Errázuriz consideró demasiado alto el monto en discusión, en tanto que, ejemplificaba, una hectárea de riego ya pagaba contribuciones territoriales, a las que se vendría a sumar el nuevo tributo. A ello Eliodoro Yáñez respondió que la idea era imponer la carga a la producción efectiva, no a las hectáreas sembradas. Para Yáñez, en el fondo, lo que importaba era que el destino del impuesto estaba dirigido hacía el perfeccionamiento de la producción vitivinícola, por medio de la elaboración de un vino tipo de exportación, para lo cual se utilizaría hasta el 50\% de lo recolectado ${ }^{124}$. A la larga no se llegó a acuerdo, y como moneda de cambio se sometió a segunda discusión también el impuesto a las cervezas. Como primer elemento para justificar la justicia de este gravamen sobre la cebada fermentada, el senador Urrejola consideró la calidad de producto industrial de la cerveza, con grandes instalaciones, bajos costos y enormes ganancias, en oposición a los vinos, que no deberían pagar impuestos pues era una actividad agrícola requerida de mayores plazos de retorno de inversión, y por ello, de riesgos ${ }^{125}$. En respuesta, Yáñez argumentó que el setenta por ciento de la ebriedad en Chile era provocada por el vino, por lo que la higiene requería que fuese recargado su valor de alguna forma. Para el senador liberal por Malleco Gonzalo Bulnes, el impuesto al vino implicaría la desaparición de miles de pequeños viticultores, que no soportarían el gravamen sobre sus productos de baja calidad y precio, estimulando el monopolio de los grandes viñateros, y por ello, beneficiando solo a unos pocos en perjuicio de muchos. Finalmente, la indicación de un impuesto de tres centavos por litro de vino fue rechaza por diez votos contra siete, con la abstención del liberal Arturo

121 BSES, 1915-1916. Debates, sesión 63a en 29 de febrero de 19161181 y 1185-1186.

122 BSES, 1915-1916. Debates, sesión 66 en 3 de marzo de 1916, 1263.

123 BSES, 1915-1916. Debates, sesión $67^{\text {a }}$ en 7 de marzo de $1916,1275$.

124 Ibid., 1280-1281.

125 Argumento muy similar había presentado a inicios de 1912 la SNA, al expresar que la búsqueda de igualdad impositiva entre la cervezas y los vinos no tomaba en consideración la calidad industrial de producción de las primeras, sus menores costos de inversión, la inmediatez de sus retornos y el hecho de que sobre el vino se acumulaban tributaciones, cosa que a su juicio no sucedía con la cerveza. BSNA, Vol. XLIII, $\mathrm{N}^{\circ} 2$, febrero de 1912, 83-85. 
Alessandri ${ }^{126}$. El impuesto a la cerveza, por su parte, se aprobó con un monto de dos centavos por litro si eran bebidas con graduación alcohólica menor de $4^{\circ}$, y de tres centavos por litro en caso de superar esa cifra ${ }^{127}$.

El paso legislativo siguiente, el retorno a la Cámara de Diputados, dado que el Senado había hecho una serie de modificaciones sobre el proyecto original, fue iniciado con la conformación de una Comisión Especial, en la que participaron, entre otros, el radical y viñatero Pedro Aguirre Cerda y el representante conservador Francisco Rivas Vicuña ${ }^{128}$. La rapidez con que se formalizaron estas etapas nos habla de la urgencia que revestía la discusión y definición final del proyecto, tanto por el largo tiempo que llevaba en las Cámaras -casi catorce años ya- como por el impacto que tendría en el desarrollo de las distintas industrias relacionadas con la producción de bebidas embriagantes. Menos de una semana más tarde, la Comisión entregó sus conclusiones, que consideraron al proyecto modificado por el Senado como óptimo, salvo pequeños detalles, entre los cuales destacaba la proposición de que el Estado entregase, por arriendo o venta a crédito, contadores mecánicos para los alambiques agrícolas, y de esa forma facilitara la determinación efectiva de este tipo de alcoholes. Sin embargo, los diputados insistían en algunos puntos de difícil solución, como los montos de los impuestos a todos los alcoholes, que el Senado había modificado: la reducción del pago por hectárea de producción supuesta de los vinos, el alza de aquel aplicado a las fábricas de alcoholes y el gravamen a la cerveza ${ }^{129}$.

El primer tema a debatirse dijo relación con la instalación de los contadores mecánicos, que según algunos serían improcedentes, tanto por la pobreza de gran parte de los pequeños destiladores agrícolas, como por las condiciones de infraestructura de los caminos rurales, que impedirían la sola llegada de estos ingenios a su destino. En caso de suceder tal cosa, respondió el diputado radical Carlos Briones Luco, sería preferible que si los destiladores eran tan pobres y estaban tan alejados, que dejaran de destilar, “...que ningún mal le harían al país si así proceden" 130 . Tras breves debates, y resaltando la necesidad de dar pronto finiquito a la discusión, pasaron a votarse cada una de las indicaciones establecidas por el Senado: por estrecho margen -26 contra 20- se aprobó establecer dos tipos de destilerías (agrícolas e industriales, adjuntándose a estas últimas a las refinerías de melaza); la obligatoriedad del contador mecánico para las destilerías agrícolas fue aprobada igualmente por 24 votos a favor y 20 en contra; el aumento de impuestos a los alcoholes promovido por el Senado fue igualmente aprobado por 39 contra 8, pero la rebaja a las fábricas de licores fue rechazada por la mayoría de los legisladores, con un solo voto a favor. Igual cosa sucedió con la rebaja al gravamen a la cerveza, rechazada por 28 diputados contra 16. El aumento al pago de las hectáreas de viñedo sí fue aprobado por 31 votos contra 13. En la sesión siguiente, se aprobó también la rebaja del impuesto para los alcoholes desnaturalizados para su utiliza-

126 BSES, 1915-1916. Debates, sesión 69a en 8 de marzo de 1916, 1315-1318.

127 Ibid., 1321.

128 BSECD; 1915, sesión $102^{\text {a }}$ en 11 de marzo de 1916, 2677.

129 BSECD, 1915, sesión $110^{\text {a }}$ en 17 de marzo de 1916, 2860-2867.

130 BSECD, 1915, sesión $111^{\text {a }}$ en 17 de marzo de $1916,2919$. 
ción industrial ${ }^{131}$. Vuelto al Senado, los legisladores de la Cámara alta decidieron insistir solamente en el punto referido a las fábricas de licores -la baja del impuesto se justificaba por el hecho de que ya pagaban el impuesto al comprar el alcohol destilado-, y en aquel alusivo a la disminución de la tributación establecida para la cerveza, que en caso de no ser rebajado no afectaría a los grandes productores, pero sí a las más de sesenta pequeñas cervecerías, que se verían obligadas a desaparecer ${ }^{132}$. Finalmente, y dado que en caso de insistir en alguna de sus recomendaciones implicaba en la práctica volver a punto cero de la legislación, la Cámara de Diputados aceptó las observaciones del Senado y dio por aprobada la ley ${ }^{133}$.

La Ley $\mathrm{N}^{\circ}$ 3087, promulgada en el Diario Oficial el 13 de abril de 1916 -es decir, menos de dos semanas luego de terminada su discusión- incluyó en su articulado las siguientes cargas impositivas para la producción de alcoholes y bebidas embriagantes: para los alcoholes de origen agrícola, 1.00 pesos por litro de alcohol absoluto; para el industrial, 1.20 pesos por litro de $100^{\circ}$; para aquel alcohol obtenido de los residuos de la fabricación de azúcar u otras materias primas importadas, 1.40; los licores salidos de fábricas nacionales, desde 0.20 pesos hasta 0.50 pesos por litro, dependiendo de su graduación alcohólica. En este ítem, se consideró una excepción: el pisco y coñac naturales, producidos por destilación y envejecimiento, sin aditivo de alcohol externo, no pagarían esta sobretasa, sino solo como alcoholes de origen agrícola. Con respecto a los vinos y chichas, el país fue dividido en dos grandes zonas vitícolas: desde Tacna a Talca, y desde el río Maule al sur. En el primer caso se pagarían 30 pesos por hectárea de regadío y 15 pesos por la de secano sembrada con viñedos; en la segunda zona, los montos disminuían a 20 pesos por terrenos con regadío, y 10 pesos por los de rulo. En caso de que la producción de dichos viñedos fuese íntegramente destilada, se exceptuaría este impuesto, debiendo cancelarse solo el asignado a los alcoholes de origen agrícola. En referencia a la cerveza, se cobrarían dos centavos por cada litro menor de $4^{\circ}$ alcohólicos, y tres para aquellas de graduación superior.

Junto a estas innovaciones, el nuevo cuerpo legal consideró también de forma manifiesta el destino que se debía dar a parte de los fondos recaudados, indicando que el $25 \%$ de la contribución percibida por el impuesto a los alcoholes y fábricas de licores se destinaría a fomentar las aplicaciones industriales del producto, así como al desarrollo de desnaturalizantes locales; a la concesión de primas de exportación para dichos productos; y a la instalación en las aduanas de la República de laboratorios químicos que certificasen la calidad y pureza de los alcoholes exportados e importados. Por su parte, el 50\% del impuesto sobre los vinos y chichas se destinaría al fomento del comercio de exportación, a la formación de vinos tipos para el comercio exterior y a la construcción de bodegas que permitiesen su óptimo almacenaje en el proceso inmediatamente anterior a su salida del país. Así mismo, un $20 \%$ del mismo gravamen debía dedicarse al fomento de la producción de vinos

131 BSECD 1915 , sesión $115^{\text {a }}$ en 21 de marzo de 1916, 3018-3024; sesión $116^{\text {a }}$ en 22 de marzo de 1916, 3030-3033.

132 BSES, 1915-1916. Debates, sesión 88 a en 29 de marzo de 1916, 1702-1704

133 BSECD 1915 , sesión $127^{\text {a }}$ en $1^{\circ}$ de abril de 1916,3358 . 
analcohólicos y la organización y fomento del consumo y exportación de uvas frescas, secas o en conserva. Por su parte, el $20 \%$ del impuesto sobre la cerveza se dirigiría hacia el estímulo a la exportación de la misma. Un 5\% más, estaría dispuesto para el fomento a la producción y comercio de bebidas analcohólicas azucaradas de frutas distintas de la uva ${ }^{134}$.

Es decir, y tras catorce años de debate parlamentario, la nueva legislación estableció dos importantes innovaciones: la aplicación de impuestos a las bebidas fermentadas, y la definición de la utilización de parte importante de lo recaudado por medio de la ley. Con respecto a lo primero, las críticas no dejaron de arreciar por parte de quienes consideraban demasiado bajo el gravamen, así como desde los que opinaban lo contrario. Con respecto a lo segundo, es importante destacar que, en su conjunto, los objetivos manifiestos de gasto se centraban en la protección de la industria vitivinícola, así como el fomento a la exportación y la transformación gradual de la industria. Se trataba así de hacer conciliar intereses muy diversos, tanto como los objetivos que la misma ley buscaba alcanzar: el aumento en el costo de las bebidas alcohólicas, el fomento a la industria vitivinícola y a la producción de alcoholes de uso industrial, la lucha contra el alcoholismo y la transformación paulatina de la industria, todo ello mediado por la necesidad de obtención de una renta fiscal más abultada que la que hasta ese momento se percibía. ¿Fueron estos objetivos cumplidos con la nueva legislación? Al menos en lo referido al último punto, el análisis de los montos recaudados es útil antes de continuar. Para ello, realizaremos un ejercicio comparativo entre la situación de ingresos antes de la aplicación de la ley de 1916, y la observada con posterioridad a ella.

TABLA 2

INGRESOS OBTENIDOS POR EL FISCO POR CONCEPTO DE IMPUESTO A LOS ALCOHOLES. 1902-1914 135

(pesos y libras esterlinas)

\begin{tabular}{lcr}
\hline Año & \multicolumn{2}{c}{ Ingresos (pesos y libras esterlinas) } \\
\hline 902 & 712.661 & $(45.105)$ \\
1903 & 768.300 & $(53.243)$ \\
1904 & 869.580 & $(59.316)$ \\
1905 & 1.429 .459 & $(93.063)$ \\
1906 & 1.929 .160 & $(115.518)$ \\
1907 & 2.915 .412 & $(154.910)$ \\
1908 & 2.607 .772 & $(104.561)$ \\
\hline
\end{tabular}

134 Lei 3087 sobre alcoholes, licores, vinos y cervezas. Promulgada en el Diario Oficial el 13 de abril de 1916, op . cit., 10,14-18. En un artículo posterior, se establecía además tanto la entrega de los fondos destinados al fomento de la exportación a sociedades cooperativas de productores, como la creación de la Dirección General de Impuestos Internos, mandatada por la ley para formar estadísticas de producción y consumo de vinos y alcoholes, la generación de propuestas para el incentivo de su uso industrial y las medidas que convendría adoptar para combatir el alcoholismo en el país. 35-36.

135 Markos Mamalakis, Historical statistics of Chile. Vol. VI. Government Srvices and Public Sector and a Theory of Services, op. cit., pp. 181-192. La conversión a libras esterlinas se ha calculado en base a Juan Braun et. als. Economía Chilena 1810-1995: estadísticas históricas, Instituto de Economía Pontificia Universidad Católica de Chile, Santiago, enero 2000. 


\begin{tabular}{lcr}
\hline Año & \multicolumn{2}{c}{ Ingresos (pesos y libras esterlinas) } \\
\hline 1909 & 1.762 .487 & $(79.177)$ \\
1910 & 2.066 .972 & $(92.855)$ \\
1911 & 2.855 .952 & $(126.425)$ \\
1912 & 3.742 .093 & $(157.894)$ \\
1913 & 3.626 .940 & $(147.316)$ \\
1914 & 2.651 .673 & $(99.090)$ \\
\hline
\end{tabular}

Las cifras presentadas por Mamalakis pueden ser corregidas en algunas ocasiones, de acuerdo a las fuentes que hemos consultado en esta investigación. Por ejemplo, y de acuerdo con la Administración del Impuesto, los montos obtenidos en los primeros años de la aplicación del impuesto alcanzaron a más de 1.200 .000 pesos ( $£ 83.160$ ) anuales, que en 1905 ya subían hasta los 1.650 .000 pesos ( $£ 107.421)^{136}$. Del mismo modo, otro autor hacía llegar el monto obtenido en 1912 hasta los 4.5 millones de pesos $(£ 189.873)^{137}$. Este efecto de incremento de las cantidades recaudadas se debió, como indicábamos másarriba, a que las reservas en manos de las destilerías industriales, que trabajaron a su máxima capacidad ante la inminencia de la promulgación de la ley en 1902, les permitió mantener bajas tasas de tributación en los primeros años. Pero una vez agotado dicho stock, la recaudación comenzó a subir, alcanzando a inicios de la década de 1910 cotas cercanas a los tres millones de pesos. Pues bien, el efecto de la nueva legislación, y en particular el ingreso de los nuevos objetos a tributación -vinos, cervezas, alcoholes destilados de residuos de la refinación de azúca- implicó un notable aumento en los fondos recaudados: entre los años 1920 y 1924, la cifra promedio recaudada alcanzó a los 6.700 .000 pesos, con una cima de más de 7.500 .000 pesos en el último año indicado, tal y como lo indica la tabla siguiente:

TABLA 3

INGRESOS OBTENIDOS POR EL FISCO POR CONCEPTO DE IMPUESTO A LOS ALCOHOLES 1920-1924138

(pesos y libras esterlinas)

\begin{tabular}{llr}
\hline Año & \multicolumn{2}{c}{ Ingresos } \\
\hline 1909 & 1.762 .487 & $(£ 79.177)$ \\
1920 & 6.669 .959 & $(£ 335.342)$ \\
1921 & 6.013 .450 & $(£ 183.336)$ \\
1922 & 6.264 .252 & $(£ 171.435)$ \\
1923 & 6.923 .356 & $(£ 186.764)$ \\
1924 & 7.621 .375 & $(£ 183.869)$ \\
\hline
\end{tabular}

136 Segunda Memoria del Administrador del Impuesto sobre Alcoholes presentada al Ministerio de Hacienda, op. cit., 45-46, 61.

137 Roberto Guzmán García, Breves anotaciones sobre la ley de alcoholes, Memoria de prueba para optar al grado de Licenciado en la Facultad de Leyes y Ciencias Políticas de la Universidad de Chile, Santiago, Imprenta, litografía y encuadernación "Núñez y Cía.”, 1914, 17.

138 Enrique Oyanedel Carroza, El problema del alcoholismo y comentarios sobre la Ley de Alcoholes, Memoria para optar al grado de Licenciado en la Facultad de Ciencias Jurídicas y Sociales de la 
Es decir, producto de las alzas de montos y los nuevos impuestos, se consiguió doblar la recaudación, efecto que se lograría replicar a partir de 1925, con la aplicación definitiva del tributo a la producción efectiva de vinos. Sin embargo, antes de pasar a ello, revisemos someramente el tipo de comentarios que la ley de 1916 generó entre los afectados por ella. Para un autor que escribía el mismo año de 1916, el mayor error contenido en la nueva ley era el impuesto a las cervezas, que amenazaba -a su juicio- con arruinar una industria floreciente que consideraba imprescindible para modificar los hábitos de consumo de los bebedores consuetudinarios. Según su opinión, lo que la ley hacía al fijar un impuesto por producción supuesta a los viñedos era motivarlos a producir más y más vinos, que pagando menor tributo conseguían mejores precios y con ello reemplazaban a la cerveza como bebida de sustitución de los alcoholes fuertes, estableciéndose así una competencia desigual que solo favorecía a los viticultores ${ }^{139}$. Una vez puesta en aplicación, el Estado buscó adicionar a la legislación de 1916 cada vez más elementos que permitiesen aumentar la tributación de los productores de vinos, al mismo tiempo que desincentivar la instalación de nuevos viñedos. Por ejemplo, sabemos que a fines de la década de 1910, el Gobierno estudió la posibilidad de imponer un gravamen anual a las viñas que se instalaran a partir de ese momento, de 1.500 pesos para las de riego y 1.000 pesos para las de secano, es decir, considerablemente mayor a lo que pagaban las ya establecidas ${ }^{140}$.

Por las mismas fechas se estableció la Comisión de Control de los Alcoholes, que reuniendo en su seno a productores, autoridades y sectores del movimiento anti-alcohólico, estudió las formas de establecer mayores inhibiciones al consumo interno, más gravámenes para los vinos y nuevas estrategias de fomento a la transformación de la industria y la exportación de sus productos. Como manifiesta paradoja, a esta comisión se opusieron con fuerza los viticultores, aun cuando eran por ley parte de ella ${ }^{141}$.

El paso clave en este sentido se dio con la proposición, en 1924, de establecer un impuesto a la producción efectiva de vinos, que debía alcanzar a cinco centavos por litro suelto, misma cantidad por media botella y diez centavos por botella. Así mismo, se buscaba la transformación en cinco años de las cuatro quintas partes del

\footnotetext{
Universidad de Chile, Santiago de Chile, Imprenta Rapad, 1930, 43. Estas cifras pueden ser corregidas a la baja si tomamos en consideración un decreto que distribuyó los montos obtenidos por estos tributos entre distintas organizaciones de combate al alcoholismo y deportivas, y que establecía que el rendimiento de todos los gravámenes sobre bebidas alcohólicas entre los años 1919 y 1923 alcanzaba a la suma de cerca de 20.500 .000 pesos, es decir, un promedio anual de 4.100 .000 pesos. Decreto $N^{\circ}$ 899. Reglamentario de los arts. 66, 67 y 171 de la lei 3,087 sobre alcoholes, vinos, licores y cervezas, Santiago de Chile, Imprenta Nacional, 1923, 133-142.

139 Guillermo Tapia C., op. cit., 36-37.

140 Carlos Gómez Quiroz, Estudios sobre el problema del alcoholismo en Chile. Memoria de prueba para optar al grado de Licenciado en la Facultad de Leyes y Ciencias Políticas de la Universidad de Chile, Concepción, Imprenta Chile, 1919, 14.

141 Enrique Zañartu Prieto y Armino Galanti, En defensa de la raza, de la viticultura y de la solución práctica del problema del alcoholismo. Por el senador de Concepción Sr. Enrique Zañartu Prieto y por el Sr. Armino N. Galanti, Director de Industrias de la Provincia de Mendoza, Liga Chilena de Higiene Social, Santiago de Chile, 1926, 93.
} 
total de la producción hacia productos no alcohólicos, persiguiéndose la máxima de que los nuevos impuestos y el aumento de los anteriores responderían a un carácter progresivo, es decir, que aunque disminuyese efectivamente la producción, los montos recaudados debían crecer. Por último, se proponía como facultad presidencial la definición de un volumen nacional de producción total, así como la prohibición de nuevos cultivos e industrias destiladoras ${ }^{142}$. Este tipo de medidas que para las organizaciones temperantes parecían confirmar la voluntad del Estado no de luchar contra el alcoholismo, sino de estar dispuesto a extraer más y más recursos de su explotación- ${ }^{143}$ representaba una verdadero giro en la política impositiva del Fisco con respecto a las bebidas embriagantes y las industrias relacionadas, en tanto buscaba dotar al Ejecutivo de la facultad de limitar efectivamente la producción, orientándola hacia su gradual desaparición.

La materialización de este tipo de medidas se alcanzó en mayo de 1925, con la dictación del Decreto-Ley $\mathrm{N}^{\circ} 1055$, firmado por el presidente Arturo Alessandri, en donde se establecieron nuevos valores para los impuestos a los alcoholes y licores, y el gravamen por producción efectiva para los vinos y chichas. De ese modo, se alzó la tributación de los alcoholes industriales a 1.80 pesos por cada litro de alcohol absoluto; aquellos producidos con residuos de melaza u otra materia prima importada deberían pagar 2.00 pesos, y los de origen agrícola, 1.60 pesos. El alcohol desnaturalizado mantendría un gravamen de diez centavos. Las fábricas de licores, por su parte, pagarían entre dos centavos y dos centavos y medio por cada grado alcohólico que contuviesen, con excepción de los aguardientes naturales y el coñac envejecido sin adición de alcoholes externos, que pagarían como alcohol agrícola. El vino y la chicha que se vendiesen sueltos pagarían un centavo por litro. En caso de comerciarse embotellados, los productores o mercaderes deberían cancelar un impuesto adicional: para los vinos de hasta un peso la botella, cinco centavos; desde ese valor hasta 1.60 pesos, diez centavos; hasta un valor de 2.20 pesos, quince centavos; desde tal cantidad hasta los tres pesos, veinte centavos; desde los 3.00 pesos hasta los 3.80 pesos, treinta centavos; si el valor llegaba a los cinco pesos, el impuesto subía a cuarenta centavos, y desde ahí en adelante, aumentaría diez centavos más por cada peso. En caso de ser vinos importados -incluyendo en ello al champagne-, el impuesto a pagar alcanzaría al doble de los antes indicados. Para la cerveza se determinó un gravamen de diez centavos por litro, independiente de su graduación alcohólica, impidiéndose la venta en el mercado nacional de cervezas con más de $7^{\circ} 144$.

Con respecto al destino que tendrían los recursos obtenidos por el conjunto de la tributación, la misma legislación estableció que cada año se utilizarían tres millones de pesos para: costear la enseñanza antialcohólica obligatoria en los esta-

142 Arsenio Sáez Mora, El alcoholismo como problema social y el ebrio ante el Derecho. Prevención y represión del alcoholismo en Chile, Memoria de prueba para optar al grado de Licenciado en la Facultad de Leyes y Ciencias Políticas de la Universidad de Chile, Imprenta Juan A. Mackenney, 1924, 93-95.

143 Vida Nueva, $\mathrm{N}^{\circ} 7$, agosto de 1924.

144 Texto completo de la Ley $N^{\circ} 1055$ de 6 de mayo de 1925, sobre alcoholes, Imprenta Inglesa, $1925,11-21$ 
blecimientos educacionales en el país, así como para financiar las medidas que cada cinco años el Presidente de la República estableciese para luchar contra el alcoholismo, incluyéndose dentro de estas la instalación de campos de ejercicio escolares, juegos atléticos, gimnasios, circos o teatros populares, "u otras diversiones para el pueblo en que no se permita el uso de bebidas fermentadas o destiladas" 145 . Con el mismo dinero se fomentarían también las aplicaciones industriales del alcohol y el desarrollo de desnaturalizantes de fabricación nacional, así como las primas de exportación de los alcoholes y licores destinados al comercio exterior y el mantenimiento de los laboratorios de las aduanas del país. Junto a ello, se fomentaría la exportación de vinos mediante la formación de vinos tipos, la construcción de bodegas de almacenamiento de estos, la organización de Estaciones Vinícolas, un Catastro de Viñas y todos los materiales y maquinarias requeridos por tales instalaciones. Se estimularía también la producción de bebidas analcohólicas, el comercio y consumo de uvas frescas, secas y en conserva, así como el establecimiento de frigoríficos especiales que permitiesen su exportación. Lo mismo con productos como la cebada y otras frutas distintas de la uva ${ }^{146}$.

De tal forma, y con el arbitrio de un decreto-ley que permitía obviar la discusión parlamentaria -que la experiencia indicaba que lograba retardar la imposición de nuevos tributos por años-, el Estado de Chile aplicaba por primera vez en su historia un gravamen directo a la producción de vinos, desmarcándose de la posición que por décadas lo había mantenido asociado antes a medidas de protección que a una inhibición concreta del desarrollo de la industria vitivinícola. Si bien las medidas de protección subsistían, lo eran solo en referencia a la exportación, es decir, a la salida del país de lo producido. A partir de este momento, el Estado incrementó de forma sistemática tanto sus ingresos por el ítem impuestos a las bebidas alcohólicas, como su poder de determinación de las condiciones en las que se desenvolvía la industria. Con respecto al primer punto, es interesante constatar aquí cómo creció la recaudación con la adición del impuesto efectivo al vino. Nuevamente es Markos Mamalakis quien nos entrega una visión panorámica del comportamiento fiscal de este ítem:

145 A inicios de 1926, el doctor Carlos Fernández Peña impulsaba a las organizaciones temperantes a exigir del Estado los fondos destinados a la lucha antialcohólica, al mismo tiempo que informaba que en San Javier de Loncomilla se había formado una cooperativa de productores que buscaban transformar su producción de vinos hacia la exportación de uva fresca. Vida Nueva, $\mathrm{N}^{\circ} 22$, marzo de 1926.

146 Texto completo de la Ley $N^{\circ} 1055$ de 6 de mayo de 1925, sobre alcoholes, op. cit. 23-24. Los costos efectivos de cada una de las indicaciones en fomento de la vitivinicultura se encuentran en un escrito de 1926, de acuerdo con el cual en este ítem debieran de gastarse cerca de 600.000 pesos en concepto de: elaboración de estadísticas y fuentes de producción de vino: 50.000 pesos; arriendo o adquisición de una bodega de almacenaje de vinos en Santiago: 226.400 pesos; pago de agentes para organizar el comercio internacional de vinos chilenos: 40.000 pesos; primas de exportación: 148.000 pesos; pago para el personal de la bodega: 69.600 pesos; reacondicionamiento de la Estación Enológica y fundación de tres establecimientos similares: 30.000 pesos; compra de material enológico: 40.000 pesos; estudio destinado a la construcción de un frigorífico en Concepción: 5.000 pesos. Enrique Zañartu P. y Armino Galanti, op. cit., 7-10. 
TABLA 4

PARTICIPACIÓN DE CADA OBJETO DE GRAVAMEN Y TOTAL DE IMPUESTOS RECAUDADOS. 1925-1930147

\begin{tabular}{cccccc}
\hline Año & $\begin{array}{c}\text { Impuesto a las } \\
\text { fábricas de } \\
\text { licores }\end{array}$ & $\begin{array}{c}\text { Impuesto a } \\
\text { vinos y chichas }\end{array}$ & $\begin{array}{c}\text { Impuesto a } \\
\text { las cervezas }\end{array}$ & $\begin{array}{c}\text { Impuesto } \\
\text { al alcohol }\end{array}$ & $\begin{array}{c}\text { Total recaudado } \\
\text { (pesos y libras } \\
\text { esterlinas) }\end{array}$ \\
\hline 1925 & 1.200 .000 & 5.200 .000 & 3.500 .000 & 4.300 .000 & $\begin{array}{c}14.200 .000 \\
(346.425)\end{array}$ \\
1926 & 1.500 .000 & 6.500 .000 & 4.200 .000 & 5.400 .000 & $\begin{array}{c}17.600 .000 \\
(444.669)\end{array}$ \\
1927 & 1.100 .000 & 7.000 .000 & 3.600 .000 & 4.600 .000 & $\begin{array}{c}16.300 .000 \\
(414.652)\end{array}$ \\
1928 & 1.600 .000 & 7.800 .000 & 4.100 .000 & 5.200 .000 & $\begin{array}{c}18.700 .000 \\
(472.819)\end{array}$ \\
1929 & 5.800 .000 & 10.000 .000 & 4.400 .000 & 4.600 .000 & 24.800 .000 \\
1930 & 6.200 .000 & 7.800 .000 & 5.500 .000 & 3.200 .000 & $\begin{array}{c}62.700 .000 \\
25)\end{array}$ \\
\hline
\end{tabular}

Como se puede observar, los nuevos impuestos, coincidiendo con las prácticas de consumo alcohólico en Chile, llegaron inmediatamente a representar más de la mitad del total de ingresos que el Fisco cobró por el ítem de impuesto a los alcoholes y las bebidas embriagantes, multiplicando a la larga por dos las cantidades recaudadas antes de la vigencia del tributo sobre la cerveza y los vinos. Esta situación, sin duda atractiva para las economías del Estado, fue fortalecida con la legislación promulgada a inicios de 1929, que tanto aumentó los montos de los tributos como profundizó las facultades del Ejecutivo en las definiciones centrales de la industria.

De tal forma, se estableció que a partir de ese año las destilerías industriales deberían desnaturalizar, exportar o dedicar a usos científicos, médicos e industriales, distintos de la bebida, el $60 \%$ de su producción, aumentando este porcentaje en diez puntos cada año hasta llegar a $80 \%$ en 1931. Sin embargo, y para asegurar una fuente de ingresos base, la cantidad destilada por cada establecimiento no podría bajar de tres mil litros de alcohol puro de $100^{\circ}$. Cada litro debía pagar 3.50 pesos de impues-

147 Markos Mamalakis, Historical statistics of Chile. Vol. VI. Government Services and Public Sector and a Theory of Services, op. cit., pp. 529-531. Los datos presentados por Mamalakis coinciden con los expuestos por dos observadores contemporáneos: Hernán Concha Garcés, Importancia Económica de la Industria Viti-Vinícola en Chile, Memoria de prueba para optar al grado de Licenciado en la Facultad de Ciencias Jurídicas y Sociales de la Universidad de Chile, Santiago, imprenta "El Imparcial", 1937, 64; y Enrique Oyanedel C., op. cit., 43. Páginas más adelante, este último autor presentaba cifras de montos pagados por las destilerías industriales, lo que permite interpretar que del total pagado por los alcoholes, estas representaron en los primeros dos años de la aplicación del decreto de 1925 cerca del $65 \%$ del total, porcentaje que descendió a menos del $50 \%$ en 1927 y 1928 , lográndose de ese modo el equilibrio entre ambos, si no en los volúmenes producidos, al menos en los pagos efectuados al Estado. 57. 
to, y en el caso de los alcoholes de procedencia agrícola, 3.00 pesos, es decir, casi el doble de los establecido en 1925. En caso de no cumplir con el porcentaje dedicado a la producción no embriagante, cada litro extra debería pagar 2.00 pesos más de impuesto; y en caso de no llegar a la cuota establecida como mínima de producción total, cada litro faltante implicaría la obligación del pago de 0.30 pesos. En el caso de los licores, desde la lógica de la tributación por grado alcohólico, se pasó a gravar su valor al consumidor: por cada peso de valor, pagarían veinte centavos de impuesto, con excepción nuevamente de los piscos y el coñac, que cancelarían solo la mitad, siempre y cuando fuesen embotellados por el mismo productor.

Los vinos, por su parte, pagarían tres centavos el litro si eran producidos al sur del Maule, así como en los departamentos de Linares y Loncomilla; y dos centavos los elaborados en el resto del país. El cálculo de producción de vino suelto se haría en relación a un rendimiento supuesto por hectárea, definido cada año para cada comuna por la Dirección General de Impuestos Internos, diferenciando entre cultivos de riego y de secano. Al momento de venderse embotellados, a este impuesto se sumaría una tasa de diez centavos por cada peso de su valor final. En caso de ser importados, el monto del impuesto se duplicaba. Con respecto a las sidras -por primera vez incluidas en la legislación- se estableció un tributo de cinco centavos por cada peso de su valor de venta. La cerveza, por su parte, mantuvo las condiciones de 1925: diez centavos por litro, cualquiera fuese su graduación, con un máximo de $7^{\circ}$. Por último, el destino de los recursos se asimilaba a lo establecido en el decreto-ley anterior (fomento a la exportación y la transformación de la industria, enseñanza antialcohólica, actividades deportivas), pero ya no fijando un monto absoluto, sino solo porcentajes relativos a cada ítem particular ${ }^{148}$.

Es decir, y esta vez tomando globalmente el periodo comprendido entre 1902 y 1930, para las arcas fiscales la aplicación de cada nueva legislación impositiva importante (1902-1916-1925-1929) implicó que en el corto plazo se doblasen los ingresos obtenidos -calculados en libras esterlinas-, los cuales rápidamente se estancaban y eran disminuidos por efectos del tipo de cambio, hasta el momento en que una legislación más agresiva al respecto permitía nuevamente doblar los montos recaudados. Como las cifras convertidas a libras esterlinas permiten comprobar, este proceso se repitió en las tres ocasiones que hemos considerado: si en 1902 la

148 Ley $N^{\circ}$ 4536. Disposiciones sobre alcoholes y bebidas alcohólicas (Conforme al Diario Oficial de 18 de enero de 1929), Imprenta Central, 1929, pp. 7-10, 12-28. Consultando la discusión parlamentaria acaecida en el proceso legislativo de esta ley, es significativo el hecho de que la mayor parte del breve debate se centró en temas ajenos a la política impositiva en tanto tal, a diferencia de todas las anteriores, y por el contrario, el proyecto aprobado finalmente fue muy similar al presentado en el Mensaje Presidencial que le dio origen. Es ello sin duda indicativo de las modificaciones sustanciales que la llegada al poder de Ibáñez del Campo implicó para la práctica política en el país, con un Congreso más dócil y un programa de gobierno que en materias como esta parecía no accesible a negociación. Ejemplo de ello es que, ya iniciada la discusión, la SNA hizo llegar a la Cámara un oficio solicitando la anulación del alza del impuesto al vino establecida en el proyecto original: este gesto fue respondido por otro oficio, esta vez del ministro de Hacienda, que rogaba no se tomase en consideración dicha petición. $B S O C D, 1928$, tomo III, sesión $84^{\text {a }}$ en 20 de diciembre de 1928, 4287-4288 y sesión $85^{\text {a }}$ en 26 de diciembre de 1928, 4371. Para el Mensaje y el Proyecto de Ley, ver BSOCD, 1928, tomo II, sesión $33^{\text {a }}$ en 21 de agosto de $1928,1478-1497$ 
recaudación alcanzó a cerca de $£ 50.000$, tres años después, una vez agotadas las reservas de las destilerías industriales, el monto superó las $£ 90.000$. Tras tocar cimas de $£ 150.000$ en 1907 y 1912, la inflación reflejada en el tipo de cambio hizo retroceder los montos conseguidos a menos de $£ 100.000$ en 1914. Sin embargo, una vez aplicada la ley de 1916 en plenitud -y en este sentido es lamentable no contar con los datos respectivos para el periodo 1917-1919-, en 1920 el volumen de ingresos dobló con creces los montos más altos de la etapa anterior, llegando ese año a más de $£ 300.000$. Pero, el lustro siguiente disminuyó notablemente -una vez más a causa del tipo de cambio y no necesariamente de la menor recaudación en pesos chilenos-, terminando por estancarse en valores similares a los del periodo anterior, es decir, poco más de $£ 180.000$. Por última vez, puesto en vigencia el decreto-ley de 1925, las cifras escalaron, ese mismo año, hasta prácticamente el doble del año inmediatamente anterior, con casi $£ 350.000$, aumentando notablemente la cantidad de dinero que entraba al Fisco, que debió lamentar, como las veces anteriores, los altibajos del tipo de cambio, estancándose la recaudación en términos de divisas en el corto plazo (algo más de $£ 400.000$ anuales entre 1925 y 1928), para retomar el crecimiento efectivo en los últimos años antes de la crisis económica global de inicios de la década de 1930, que si bien escapa a nuestro estudio, suponemos terminó de forma abrupta con este breve bonanza fiscal, como ya lo parece indicar el descenso producido en 1930.

A pesar de lo anterior, de todas formas el Estado encontró en los distintos gravámenes a las bebidas embriagantes y el alcohol una fuente de recursos que, en términos de dinero nacional y divisas, experimentó un sostenido aumento por efecto de las legislaciones correspondientes, siempre y cuando estas abarcasen cada vez más cantidad de productos sujetos a tributación, al mismo tiempo que se aumentaba el valor relativo de los impuestos a pagar. Observando los montos en moneda nacional, no deja de ser significativo que entre 1902 y 1929 la cantidad de pesos ingresados al erario pasase de menos de un millón a casi veinticinco millones, aun cuando su conversión a libras esterlinas nos informe de la magnitud efectiva de este crecimiento: si en 1905 ingresaban $£ 90.000$, en 1929 este monto llegaba a casi $£ 630.000$. Es decir, en pesos los montos se multiplicaban por 25; en libras esterlinas, por siete. En el fondo, y he ahí quizás lo más interesante, el comportamiento de la tributación se asimilaba en mucho al de la producción, que entre 1870 y 1930 multiplicó su volumen por diez ${ }^{149}$.

Ello explica que los precios, por el contrario, no aumentasen en similar proporción, quedándose relativamente estancados al ser confrontados con las dos variables anteriores. Es decir, el aumento de los montos recaudados se relacionó con la ampliación de los objetos gravados, no con el alza final del precio del producto. Como consecuencia, la oferta y la demanda de bebidas embriagantes no dejaron de crecer, y el supuesto primer objetivo de toda la política impositiva -encarecer el

149 Marcos Fernández L., Historia Social del Alcoholismo en Chile. 1870-1930, op. cit., parte primera. 
precio final de las bebidas alcohólicas con el fin de inhibir su consumo- no se logró. Pero, y ello es evidente, lo que sí se modificó fue la posición de los productores y la función que el Estado asumía con respecto a la elaboración de bebidas alcohólicas, en tanto se alcanzaron grados de intervención fiscal nunca antes vistas, como la definición de cuotas de producción o la determinación del destino de los alcoholes producidos.

Cada uno de estos puntos generó comentarios en la época, de parte de distintos actores involucrados en el tema de la lucha contra el alcoholismo o la producción de bebidas alcohólicas, así como en estudiosos de la legislación y el comportamiento productivo. Por ejemplo, en 1925 un periódico temperante saludaba el regreso de Alessandri al poder, pero esperaba que se derogase el nuevo impuesto a los vinos y chichas, en tanto consideraba inmoral que el Estado lucrase con el vicio en vez de extirparlo de una vez por todas por medio de la adopción de un régimen prohibicionista ${ }^{150}$. Según otro autor, la nueva legislación se había preocupado única y exclusivamente “...si se nos permite decir, de encaminar las leyes a fines económicos y materiales, que a asentar también principios básicos contribuidores de la salud pública y privada" 151 . Y por lo mismo, pero en las facultades discrecionales del Ejecutivo con respecto a las industrias fabricantes de bebidas alcohólicas, las organizaciones contrarias al alcoholismo estuvieron de acuerdo con los alcances de la nueva ley, e incluso exigieron más: aumento en el fomento a la producción de analcohólicos, alza en las primas de exportación, indemnización a los viñateros que no produjeran alcohol ni vino, mayores tributos a las viñas plantadas tras la promulgación de la ley, con una sobretasa por cada litro de vino producido; prohibición de la instalación de nuevas industrias cerveceras y destiladoras; determinación estricta de cuotas de producción; obligación de los importadores de gasolina de ocupar al menos un $10 \%$ de alcohol en sus combustibles ${ }^{152}$.

150 Vida Nueva, $\mathrm{N}^{\circ} 12$, abril de 1925 . Con respecto a la aplicación efectiva de medidas prohibicionistas en Chile, puede representarse así en la instalación de Zonas Secas como en el régimen laboral establecido en los yacimientos mineros de capitales estadounidenses. Ver de Thomas Miller Klubock, Contested Communities. Class, Gender and Politics in Chile's El Teniente Copper Mine, 1904-1951, Duke University Press, Durham, North Carolina, 1998; Stefan Rinke, Cultura de masas, reforma y nacionalismo en Chile. 1910-1931, DIBAM-Katolische Universitat Eichstatt-Universidad Católica de Valparaíso-Centro de Investigaciones Diego Barros Arana, Santiago, 2002; Marcos Fernández L., "Las comunidades de la sobriedad: la instalación de zonas secas como método de control del beber inmoderado en Chile, 1910-1930", en Scripta Nova, Revista Electrónica de Geografía y Ciencias Sociales, Universidad de Barcelona, Vol. IX, No 194, 1 de agosto de 2005. http://www.ub.es/geocrit/sn/sn-194-59.htm

151 Ramón Reyes Pérez, Ante la Reforma de la Ley de Alcoholes, Memoria de prueba para optar al grado de Licenciado en la Facultad de Leyes y Ciencias Políticas de la Universidad de Chile, Santiago de Chile, imprenta y litografía "La Ilustración", 1926, 8-9. A su juicio, ello se debía a que “....nuestros legisladores, en gran parte, haciendo honor a la verdad, no cuentan con una sólida cultura y experiencia jurista en el campo de la medicina legal para legislar sobre materias que tiene directa relación en todo y por todo con la ciencia médica".

152 Proyecto de Reforma de la Ley de Alcoholes, Redactado por el Dr. Carlos Fernández Peña por encargo de las tres instituciones [Asociación de Educación Nacional, Liga Chilena de Higiene Social y Liga Nacional contra el Alcoholismo] y en Defensa de la Raza, de la Viticultura y de la solución práctica del problema del alcoholismo. Patriótica cooperación a la labor de S.E el Presidente de la República Exmo. Señor Carlos Ibáñez del Campo y del Congreso Nacional, establecimientos gráficos "Balcells \& Co.", Santiago, 1928, 6-7. 
Los viticultores organizados, por su parte, no se manifestaron tan insistentemente como se podría haber esperado en contra de los nuevos impuestos, en tanto que sus productos quedaron en una posición de privilegio frente a las otras bebidas, estuvieran estas dotadas de mayor o menor poder embriagante.

Una vez promulgada, la nueva política impositiva no fue atacada con virulencia, debido a que parte importante de los recursos recaudados iban a fin de cuentas al fomento de su actividad, en particular por el estímulo a las exportaciones. Asimismo, el cobro de un gravamen sobre cada litro producido era una alternativa -defendida por sectores de los mismos viticultores-para levantar los precios, combatir la sobreproducción y mejorar la calidad de sus productos. Sin embargo, consideraron preferible el impuesto por hectárea cultivada a aquel que establecía como base de cálculo la producción, aduciendo “....razones de equidad: no castigar al que más trabaja y mejor produce, sino promover un uso más intensivo de la superficie cultivada" 153 . Una vez aprobada la ley, no volvieron sobre el particular: sabían tanto que las condiciones políticas habían cambiado, y que ya el Congreso no era la arena de transacciones y dilaciones que, antes de la llegada de Ibáñez al poder, había permitido demorar catorce años la promulgación de una ley. Las cosas habían cambiado, y ello nos sirve para confirmar el estrecho lazo que unió, durante todo el periodo que hemos abarcado en este estudio, a la política, los intereses productivos, la lucha contra el alcoholismo y la estrategia impositiva, tal y como pasamos a revisar a continuación.

\section{PODER POLÍTICO, INTERÉS PRODUCTIVO Y CACICAZGO LOCAL: LA INFLUENCIA POLÍTICA DEL ALCOHOL EN CHILE. 1870-1929}

En el Chile de las últimas tres décadas del siglo XIX y las tres primeras del siglo XX coexistieron distintas formas en las que se evidenció la relación establecida entre los intereses de los sectores productores de bebidas alcohólicas, los movimientos contrarios a su consumo y las autoridades de gobierno local y nacional. Quizás la más visible y pública fue el derecho de petición que amparaba constitucionalmente a todos los ciudadanos, y que les permitía hacer llegar sus opiniones, solicitudes y quejas a las distintas esferas del poder político. Multitud de ruegos y malestares fueron informados de forma directa, desde productores o de opositores a las bebidas alcohólicas, al Congreso Nacional, los ministerios o los funcionarios a cargo de tal o cual medida de carácter local o general. Su seguimiento demuestra la permanencia de una expedita vía de comunicación, a veces

153 La Viña, $\mathrm{N}^{\circ} 7$, febrero de 1928, p. 42. Con posterioridad, sí expresaron su desacuerdo con las políticas arancelarias que buscaban desincentivar la introducción de maquinaria vitivinícola, al constatar que la importación de alambiques de destilación era gravada en menor medida que estas. La Viña, $\mathrm{N}^{\circ}$ 9, abril de 1928, 106. Con respecto al comportamiento organizacional de los productores vitivinícolas y sus relaciones con el Estado, ver de mi autoría "Rivalidades de aldea y gran sociedad vinícola: las organizaciones de productores vitivinícolas en Chile, 1870-1930", en Universum, Universidad de Talca, 2006 (en prensa). 
más efectiva para unos y menos para otros, que hizo referencia a los distintos tópicos que las políticas públicas sobre el alcoholismo y las bebidas embriagantes tomaban en cada etapa de la discusión. Por ejemplo, a inicios de la década de 1880 el Boletín de la Sociedad Nacional de Agricultura recordaba su "guerra activa i nunca interrumpida contra los derechos específicos sobre las bebidas fermentadas", a la vez que su constante presión por el alza en los aranceles sobre los productos importados que pudiesen dañar la producción nacional. Y para ello, se hicieron oír por el Congreso cuantas veces fue necesario para lograr sus objetivos ${ }^{154}$.

Con igual claridad y hasta porfía, desde el primer momento en que se demostró plausible la aplicación de un impuesto sobre sus industrias, los destiladores del sur del país hicieron llegar a las autoridades su malestar al respecto ${ }^{155}$. Sin embargo, al interior de la misma Cámara se sabía que sus apoyos políticos eran escasos, por lo que no serían capaces de generar ni un movimiento de opinión, ni una estrategia de aplazamiento de la discusión efectiva. Como ejemplo, el diputado liberal democrático por Quillota Roberto Meeks consideraba que a diferencia de Alemania “...en Chile no existen estos intereses poderosos de los fabricantes de alcoholes industriales, que pueden hacer la guerra a una lei contra el alcohol"156. Una vez aprobada la legislación, un autor comentaba que la posición en que quedaron las destilerías industriales, que consideraba "un asunto ruinoso, el mejor camino para una bancarrota", se debió a la "...independencia política de los industriales que se ocupan de la destilación de alcoholes"157. Esta situación, sin embargo, no desanimó a los industriales, que en septiembre de ese mismo año hacían llegar al Congreso una solicitud que, en vistas a la pronta reforma de la ley recién promulgada, expresaba su esperaza de que los impuestos agrícolas e industriales fuesen equiparados ${ }^{158}$. Algunos años más tarde, y ya iniciada la discusión para la transformación de la ley vigente, los productores de Valdivia, La Unión y Osorno hacían lo mismo ${ }^{159}$.

Quienes sí demostraron una y otra vez su capacidad de influencia sobre las discusiones parlamentarias fueron los productores de vinos, que lograron postergar hasta el año 1925 la aplicación de un impuesto efectivo sobre su producción. Ya antes de ser promulgada la primera ley de alcoholes, la proposición del diputado -y después senador conservador- Gonzalo Urrejola de tramitar de forma separada la ley

154 BSNA, Vol. XIII, N²1, agosto de 1882, 409-413.

155 BSNA, Vol. XVIII, N ${ }^{\circ} 23$, septiembre de 1887, 751.

156 BSECD, 1900, sesión $41^{\text {a }}$ en 11 de enero de $1901,928-929$. Un caso de persistente presencia de los industriales del alcohol destilado en las discusiones políticas referidas a las medidas antialcohólicas - con diversos resultados a lo largo del tiempo- es el que estudia para Inglaterra Peter Mathias, "The Brewing Industry, Temperance and Politics", en The Historical Journal, vol. 1, N ${ }^{\circ} 2$, 1958, pp. 97-114. De acuerdo a otra investigación, el inicio de esta influencia política habría estado, justamente, en la aplicación de impuestos específicos sobre la producción de destilados escoceses, con el fin de aliviar el déficit impositivo de Inglaterra motivado por la guerra en las colonias de Norteamérica. Vivien E. Dietz, "The Politics of Whisky: Scottish Distillers, the Excise, and the Pittite State", en The Journal of British Studies, vol. 36, $\mathrm{N}^{\circ} 1,1997,35-69$.

157 J. Modesto I. de M., op. cit., 31.

158 Sindicato de Destiladores Industriales de Chile, Apreciaciones sobre la reforma de la ley de alcoholes a propósito de la última publicación de la Liga Vinícola, op . cit., 10.

159 BSECD, 1903, sesión 49a en 11 de enero de $1904,1044$. 
sobre falsificación de vinos y el resto del cuerpo legislativo en discusión, fue vista por uno de sus colegas -el representante liberal por Laja, Daniel Rioseco Britocomo una estrategia para beneficiar a la viticultura y luego, por medio de la obstrucción "...hacer un doble negocio que traería como consecuencia el aumento del alcoholismo"160. Años más tarde, y finalizándose el debate de la ley de 1916, el senador conservador Joaquín Walker Martínez resumía todas las influencias que los grandes viñateros habían puesto en juego para impedir el cobro de un gravamen efectivo sobre sus productos, expresando su sorpresa de que a fin de cuentas “...sean los viticultores los que hagan las leyes que gravan los alcoholes en nuestro país, i que no haya en esta Cámara cuatro o seis senadores de buena voluntad que se propongan analizar i contemplar esta cuestión desde distintos puntos de vista" ${ }^{161}$. Consecuente con esta opinión, el mismo senador acabó por acusar al representante de Ñuble Gonzalo Urrejola de legislar en función de sus propios intereses, en tanto él mismo era destilador agrícola, y abusaba -de acuerdo a datos que Walker Martínez tomaba de las memorias de la Administración del Impuesto- del cobro por rendimiento supuesto, en tanto producía más del doble de lo que efectivamente tributaba. Ante la molestia del mismo Urrejola, Walker Martínez lo conminó a abstenerse de votar y participar en los debates, en tanto actuaba como juez y parte, en contradicción flagrante con el artículo 104 del reglamento del Senado que prohibía la intervención en asuntos de propio interés. El senador por Ñuble no hizo tal, y finalmente la imposición a los vinos se limitó a la producción supuesta ${ }^{162}$.

Entrado en vigencia el Decreto-ley que aplicó el impuesto efectivo al vino, sin embargo, la posición de los viticultores no se vio desmerecida de la forma que cabría esperar, dado que una parte importante de los recursos recaudados a la larga serían destinados al fomento de su propia actividad, por medio de primas de exportación, construcción de bodegas y desarrollo enológico. Esta situación ponía de manifiesto, para un autor contemporáneo, el peso que seguía teniendo el gremio viñatero al momento de las decisiones político-económicas del Estado, indicando de forma irónica ante esta medida: "iQué prudencia demuestra el legislador cuando median los intereses de la oligarquía del alcohol!"163. Sin embargo, la evaluación que los mismos productores hacían era distinta, y revestía tintes de amenaza a su actividad que consideraban innegables: una situación en que la politización del tema de la represión del alcoholismo había alcanzado cimas que presentaban a las viñas como "bienes raíces exclusivos de un partido político", y por ello objetivo de destrucción de parte de sus oponentes (en referencia al conservadurismo y la posición liberal de Alessandri durante los primeros años de la década del 1920). Con-

160 BSOCD, 1901, sesión 52a en 26 de agosto de 1901, 646

161 BSES, sesión $24^{\mathrm{a}}$ en 2 de diciembre de $1915,395-401$.

162 BSES, 1915, sesión 43a en 12 de enero de 1916, 773-778 y sesión $46^{a}$ en 19 de enero de 1916 , 808-814. Con respecto al tributo a la cerveza, Walker Martínez sostuvo similar opinión: “...o puedo aceptar que en el Congreso de Chile, en el cual no está representada la industria de la cerveza por un solo señor Senador, i sí la de los vinos por muchos de ellos, entre a dirimir esta contienda". BSES, 1915 , sesión $69^{\text {a }}$ en 8 de marzo de 1916, 1321.

163 Ramón Reyes P., op. cit., 49. 
cluida en principio esta etapa, los viticultores miraban con desconcierto la actitud de la “...Revolución de Septiembre, que no llegó a paralizar el poder del grupo adversario de la Viticultura, pues hemos visto que en este último tiempo se han multiplicado las leyes y reglamentos que la gravan sin contemplación algun"164.

En el fondo, con la dictadura de Ibáñez del Campo las concesiones a la industria vitivinícola se redujeron, y en la estrategia del gobierno primó la necesidad de recursos para el Estado antes que los cabildeos que habían logrado introducir mediaciones entre este interés y los privilegios de la industria. Sabemos que las políticas de protección al vino no hicieron sino incrementarse a lo largo de la década de 1920 e inicios de 1930, pero por los bajos resultados en la exportación, el fruto económico de estas medidas no aportó beneficios inmediatos ${ }^{165}$. Por el contrario, el cobro de impuestos sí lo hizo, y esa situación era suficiente para la realpolitik que el régimen anhelaba practicar.

Para otros actores de opinión -a lo largo de la etapa que va desde fines del siglo XIX hasta las primeras décadas del XX-, todo este tipo de peticiones, solicitudes, influencias y privilegios desde y hacia los productores y expendedores de bebidas alcohólicas lo que hacían era reflejar las presiones que los sectores económicamente involucrados ejercían sobre las autoridades ante la eventualidad de cualquier tipo de lesión sobre sus intereses inmediatos. Con motivo de la larga discusión acaecida a inicios de los años de 1890 en el seno del Consejo Superior de Higiene en torno a las exigencias de pureza de los alcoholes expedidos al público, la Sociedad Médica expresó que el debate no llegaría a su fin “...mientras los intereses de ciertas personas estriben en el perjuicio de los otros, y mientras no se tenga la energía necesaria para arbitrar un sistema de medidas que, sin consultar conveniencias personales, entre por el camino de la convivencia general de la comunidad", en clara referencia a la oposición de opiniones entre los productores agrícolas de alcohol y los destiladores industriales ${ }^{166}$. Por su parte, las organizaciones de temperancia constantemente se dirigieron, a través de sus medios de prensa, a los gobiernos, conminándolos a no dejarse presionar y a tomar las medidas necesarias contra el vicio. Con el sugerente título de El Gobierno, una publicación temperante incluía en sus páginas las siguientes máximas, que las autoridades debían recordar al momento en que estaban sometidas a la presión de los taberneros y expendedores con motivo de la pronta promulgación de la Ordenanza de 1892 que reglamentaba las cantinas en sus horarios y patentes:

Debe castigar a los ebrios

Debe quitar el aguardiente del país

Debe excluir la chicha de uso común

164 La Viña, $\mathrm{N}^{\circ}$ 5, diciembre de 1927, 14-15.

165 Marcos Fernández L., Historia Social del Alcoholismo, op. cit., 192-198.

166 RMCh, tomo XVIII, año 1889-1890, 68. El texto concluye: "Nada más precioso para un país que su salud, y para poseerla no deben ahorrarse medios ni eximirse de sacrificar cualquier interés secundario, hasta algunas industrias, si es preciso, puesto que tras ellas tratan de guarecerse profundas imperfecciones sociales". 
Debe vigilar bien las casas de montepío

Debe prohibir la fabricación de licores malos

Debe prohibir la internación de pisco, ron y whiskey

Debe sacar multa a los que venden licores a los ebrios y a los niños

Debe quitar del país el vicio de la embriaguez por un modo u otro

Debe mirar constantemente por el bienestar de todos los ciudadanos

Debe dictar medidas para mejorar la condición de la gente trabajadora

Debe prohibir el expendio de licores el día domingo y en los días de fiesta ${ }^{167}$.

Una vez aprobada la normativa de 1892, los mismos temperantes la consideraron letra muerta, y ello por responsabilidad directa de los legisladores que la habían firmado, en tanto, aducían, “...los hombres que rigen los destinos de la Nación siguen agregando cuadra tras cuadra a sus propias viñas" ${ }^{168}$. Y por eso, la única actitud que daría esperanzas a los abstinentes de que los poderes políticos efectivamente luchasen en contra del alcoholismo era que siguiesen el ejemplo de Inglaterra, en cuyo Parlamento informaban había cerca de cincuenta representantes abiertamente temperantes, misma actitud que pedían a las autoridades municipales, de las intendencias, de las policías, y así dejasen de ser "...los rufianes de los taberneros" 169 . En la misma línea de radicalidad retórica, dicho medio criticaba la demora en la discusión de la primera ley de alcoholes acusando a los legisladores de que "...también hai entre vosotros numerosos tipos de rostros asquerosos i de hechos inmorales, eso sí que cubiertos con trajes finísimos, que es como si dijéramos sepulcros blanqueados, hermosos por fuera i asquerosos por dentro" 170 . Poco después, esta vez con nombre y apellido, se criticaba la ignorancia de los diputados liberales Meeks y Yáñez: al primero por no entender nada de química y por ello defender la tesis de que los alcoholes agrícolas eran menos nocivos que los industriales, y al segundo “...por cifrar sus esperanzas de regeneración del país en proyectos i más proyectos que irán fracasando a cual mejor conforme vayan saliendo bonitos i flamantes del laboratorio del Congreso i de la Moneda"171.

167 La Cinta Azul, $\mathrm{N}^{\circ}$ 14, julio de 1892. En contraposición, en otro número la misma publicación informaba la realización de un meeting convocado por los expendedores en repudio de la nueva Ordenanza, a la que habrían asistido, de acuerdo a la prensa, cerca de 18.000 personas, cifra que el periódico reduce a solo dos mil. La Cinta Azul, $\mathrm{N}^{\circ} 15$, agosto de 1892.

168 La Cinta Azul, $\mathrm{N}^{\circ} 32$, abril de 1894. El artículo concluía expresando: "Es preciso que nuestros ministros se ocupen menos en la política y más en cuidar el bienestar de los habitantes del país".

169 El Abstinente, $\mathrm{N}^{\circ} 4$, octubre de 1897.

170 El Abstinente, $\mathrm{N}^{\circ}$ 6, diciembre de 1897.

171 El Abstinente, $\mathrm{N}^{\circ}$ 51, septiembre de 1901. Coincidía en este juicio la SNA, en tanto que expresó sobre los parlamentarios liberales Eliodoro Yáñez y Marcial Martínez -ambos enemigos de los privilegios al alcohol agrícola- de forma irónica que: “...sus opiniones en materia forense son autorizadísimas, i que en el desempeño de la profesión que ejercen son verdaderas eminencias. Pero, si autoridades son como abogados, en lo que respecta a la materia sobre la que deben ahora informar, han dado suficientes pruebas no solo de que no poseen los conocimientos indispensables, sino también de que padecen algunos errores graves, de los cuales es imposible desentenderse". BSNA, Vol. XXXIII, $\mathrm{N}^{\circ} 27$, julio de $1902,665-666$. 
Ya promulgada la Ley $\mathrm{N}^{\circ} 1.515$, los medios temperantes conminaban a las clases políticas: “...!Completen su obra los señores legisladores entrando de lleno en la abstinencia espontáneamente y dando el ejemplo al país y entonces habrán hecho obra provechosa!" ${ }^{172}$. Pero ello no ocurrió, y por el contrario, las críticas de la connivencia entre los intereses de los productores de bebidas embriagantes y la clase política no dejaron de arreciar. Ya entrada la década de 1910, un comentarista observaba que las dificultades que encontraba la ley de alcoholes en su proceso de reforma se debían fundamentalmente a que “...se ha formado en nuestro país una oligarquía de viticultores que tienen gran influencia en el Estado y que ocupa muchos sillones en el Congreso. A esa oligarquía le conviene que se beba más y mejor" 173 . Como ya sabemos, la ley de 1916 no modificó la tributación vitivinícola, y debió esperarse casi diez años a partir de esta para que el impuesto a la producción efectiva de vino fuese una realidad. Sin embargo, con la candidatura y posterior elección de Arturo Alessandri Palma como Presidente de la República, el programa de acción de los abstinentes moderados o absolutos se radicalizó y tornó maximalista. Por primera vez la buena acogida del Ejecutivo ante la solicitud de medidas como las Zonas Secas hizo que este tipo de asociaciones confiasen en que sus principios serían rectores de política, y con un primer mandatario que se vanagloriaba de no conocer la ebriedad y haber hecho arrancar las viñas de su propiedad, sus esperanzas podían estar bien fundadas ${ }^{174}$. Pero, y a poco andar el gobierno de Alessandri, las influencias de los viñateros en el Congreso se dejaron sentir, con la creación de las zonas de temperancia limitada y el rechazo al aumento en las contribuciones al vino ${ }^{175}$. Y los temperantes por su lado, se decepcionaban del hecho de que el Estado considerase conseguir mayores recursos fiscales con sus nuevas políticas de tributación, por lo que lo tildaban de “...gran alcoholizador de nuestra raza" 176 . Esta situación con el paso de los años no dejaría de profundizarse, dados los mayores volúmenes de recursos que el ítem de la tributación sobre los alcoholes aportaba al Fisco.

Sumándose a los dos planos anteriores de relación entre política y bebidas embriagantes -peticiones de actores, críticas a la actuación de los poderes públicos- la vinculación entre el alcohol y el ejercicio del poder político quedaba de manifiesto también en la generación de las autoridades parlamentarias y municipales, las que, de acuerdo al común de los observadores contemporáneos, utilizaban a las tabernas y cantinas como espacios de obtención de votos, más específicamente,

172 El Abstinente, $\mathrm{N}^{\circ} 58$, abril de 1902.

173 Fernando Sandoval H., op . cit., 20.

174 El alcoholismo $i$ las enfermedades sociales juzgados por el Presidente de la República, la Iglesia, la Ciencia Médica i el Proletariado Chileno, Santiago de Chile, Imprenta Universitaria, 1921, 5-9.

175 Arsenio Sáez M., op. cit., 14.

176 Vida Nueva, $\mathrm{N}^{\circ} 7$, agosto de 1924. Una opinión más moderada, de fuerte apoyo a Alessandri pero de similar rechazo a la dependencia del erario con respecto al impuesto al vino, manifestó la Sociedad Médica en sus "Acuerdos sobre la solución del problema del alcoholismo", en $R M C h$, tomo LIII, 1925, 370-372. 
de carneros, como se llamaba en la época a los electores asegurados por algún capataz electoral para un determinado caudillo local, ya fuera en los municipios o en las justas por el Congreso Nacional ${ }^{177}$. Antes de finalizar la década de 1880 , el joven médico Vicente Dagnino opinaba que, “...por lo que toca a las libertades, garantías i derechos, nuestras épocas electorales dan vergonzosa muestra de lo que puede sobre ellos [los pobres] la avidez alcohólica, tal es el embrutecimiento a que han llegado: los partidos luchan a porfía por atraerse al pueblo embriagándolo, i por tanto embruteciéndolo"178. Poco después, y dando cuenta del mismo fenómeno, un comentarista de Valparaíso consideraba necesaria la expropiación de los derechos políticos de los consumidores inmoderados de alcohol, dado que "...el consuetudinario no puede ser buen ciudadano, vendería a su nación por un vaso de vino. En política trabajaría a favor de los dueños de la taberna a fin de conseguir gratis el licor" 179 .

Los hechos parecían reforzar la idea de que en la práctica eran los hombres vinculados al negocio del alcohol quienes podían dirimir las contiendas electorales, y por ello, tenían facultades de rápida alteración de las normativas que les afectasen. Por ejemplo, con respecto a la pronta modificación de la Ordenanza de 1892, en el sentido de diferenciar las bebidas fermentadas de las destiladas para la reglamentación de su expendio, Benjamín Dávila Larraín explicaba que ello se debió al temor de los legisladores de "perder algunos votos para futuras elecciones" dadas las "...influencias considerables de los taberneros"180. De tal forma, para nadie parecía ser un misterio que "...los partidos políticos i las policías reclutan sus mejores ganadores de elecciones, entre esa casta inescrupulosa de los bodegoneros que arrancan al pueblo el salario de la semana"181.

Ya a fines del siglo XIX, para los estudiosos del tema de la ebriedad, la ligazón establecida entre elecciones y borrachera era transparente, denunciándose que “...en las épocas eleccionarias los partidos políticos, cuál más, cuál menos, instalan en los centros electorales, tabernas gratuitas, en donde se alienta el espíritu político i se corrompe la conciencia de los ciudadanos. Por un vaso de chicha, por un trago de venenoso aguardiente, los electores olvidan sus deberes cívicos i los que aún conservan despojos de moralidad, los pierden allí entre las frases viciosas de los oradores o entre los vapores de la bacanal política" ${ }^{182}$. Los mismos parlamentarios lo reconocían: cuando estaba en discusión la primera ley de alcoholes en

177 Similar función de la taberna como lugar de reclutamiento de electores ha sido señalada, para el caso de los Estados Unidos, por Jon M. Kingsdale, "The "Poors Man's Club": Social Functions of the Urban Working-Class Saloom”, en American Quarterly, vol. 25, N 4, 1973, 472.

178 Vicente Dagnino O., op. cit., 8.

179 Eliseo Núñez G. La embriaguez, sus consecuencias y su curación, Valparaíso, Imprenta Arrayán, 1890, 7. Una vez propuesta en el Congreso la posibilidad de que los ebrios fueran impedidos de votar, el senador conservador Carlos Walker Martínez se opuso, en tanto "...dada la condición en que se hacen las elecciones, creo que esta disposición no puede presentarse sino a abusos. Sucederá que aparecerán como ebrios todos los que no sean del partido del Gobierno". BSES, 1901-1902, sesión 50a en 9 de enero de 1902, 1023.

180 Benjamín Dávila L., op. cit. 40 y 64. Concluye: “Triste democracia sería la de Chile si hubiera de defender la libertad de embriaguez!"

181 Jorge Rodríguez C., op. cit., 6. 
el Congreso, y ante la proposición de que se les entregase a los trabajadores una papeleta de buena conducta y residencia, de parte de sus patrones, para que pudiesen disminuir su paso por la prisión en caso de ser detenidos por ebriedad, el Senador liberal democrático José María Balmaceda se oponía resueltamente, dado que ello implicaría que “...en vez de una lei de moralidad pública, habríamos hecho una lei política o que podría utilizarse como recurso político en época de campaña electoral. Fácilmente se comprenderá que el alcalde imprimiría papeletas a favor de los que comprometieran su voto aunque no vivieran en la localidad, i les negaría o pondría mil dificultades para darlas a aquellos con quienes no pudiera contar" 183 . De igual modo, y ante las acusaciones de que el establecimiento del monopolio -o la sola conformación de una nueva administración para gestionar el impuesto a los alcoholes- se convertiría en una poderosa maquinaria de intervención electoral de parte del Estado, el diputado conservador por Constitución José Miguel Echenique argumentaba: “ ¿Acaso hoy, sin legislación alguna sobre el alcohol, no tenemos un poder electoral en manos cien veces más peligrosas, más irresponsables que las de nuestros gobernantes? Hoy los dueños de la elección son los dueños de las tabernas" 184 .

Por todas estas razones, la proposición de obligar al cierre de las tabernas en días de elecciones fue bien vista por muchos sectores, incluso por los agricultores organizados, que a pesar de su tradicional defensa de los intereses vitivinícolas, consideraban este tipo de medidas necesarias para no continuar observando el espectáculo de la ebriedad en víspera de votaciones, como la describía un redactor a inicios del siglo XX: “...cualquier aldehuela en un día de votaciones ofrece un ancho campo al observador, al artista i al sociólogo: nadie duda que i respecto al número de pobladores, en un día de estos una comuna rural consume más vino, aguardiente $\mathrm{i}$ chicha que una comuna urbana, i con el añadido de que en las primeras son los patrones los que directamente se encargan de embriagar, comprar $i$ hacer que lo pasen bien sus inquilinos i sus amigos" 185 . Justamente, a los mismos votantes que se dejaban arrastrar a las urnas bien borrachos para votar, se dirigía un periódico temperante, cuando les advertía que “...el alcohol, por último, es aquello de que se valen los explotadores para haceros acallar la voz de la razón o de la conciencia, para entorpecer vuestro cerebro i, perdóneseme la palabra, para arrearos como carneros a sufragar en la época de elecciones" ${ }^{186}$. Haciéndose parte

182 Luis A. Navarrete y Conrado Ríos, op. cit., 113-114.

183 BSOS, 1895, sesión en 11 de noviembre de 1895, 211.

184 BSOCD, 1899, sesión $38^{\text {a }}$ en 30 de agosto de $1899,811-815$.

185 BSNA, Vol. XXXII, N 43 , octubre de 1901, 890-900.

186 El Consejo de Temperancia, $\mathrm{N}^{\circ} 3$, octubre de 1900. Argumentos muy similares son los que expuso parte importante del movimiento obrero organizado a inicios del siglo XX en referencia al alcohol y el beber inmoderado, relacionándolo tanto con la consolidación de una oligarquía licorera como con un medio de embrutecimiento y manipulación electoral. Al respecto ver de mi autoría "Beber para trabajar o trabajar para beber: el consumo inmoderado de alcohol entre los trabajadores chilenos y el problema de la alienación en el movimiento obrero organizado. Chile, 1900-1930, ponencia presentada en las XVI Jornadas de Historia de Chile, Universidad de Los Lagos, Osorno, 4-7 de octubre de 2005 . 
de la misma opinión, Eliodoro Yáñez se quejaba en el Parlamento que “...de año en año la influencia del alcohol se hace sentir con mayor eficacia en la generación de los poderes públicos, i de año en año el pueblo se hace menos apto para gobernar, para elegir a sus gobernantes"187. Y el demócrata Malaquías Concha sostenía lo mismo cuando agregaba: “...el cincuenta por ciento de los ciudadanos que hoy van a votar lo hacen sin saber lo que hacen, porque se les embriaga primero para obtener sus sufragios después"188.

Con la entrada en vigencia de la ley de 1902, la situación de complementariedad entre los candidatos y los dueños de locales de expendio de bebidas alcohólicas no se modificó, tal como tampoco lo había hecho con la aplicación de nuevas patentes municipales diez años atrás. Con respecto a Santiago, un comentarista exponía: “...los comisarios de la Policía de la capital exigían a cada cantinero clandestino, por lo menos, dos electores para el candidato de sus afecciones" 189 . Para otro autor, la determinación de la opción impositiva sería aprovechada por el Estado para pagar favores políticos, por medio de la contratación de nuevos empleados públicos, “...esa conocida clase de hombres que no saben desempeñar otra ocupación que dormir en los bancos de las oficinas públicas y recibir el último día de cada mes el dinero de los contribuyentes, como premio a tanta abnegación!"190. Ya en el Centenario, un estudiante de último año de Derecho seguía considerando que la imposibilidad de aplicación de la prohibición absoluta del consumo de alcoholes en Chile se debía tanto a la protección que el Estado daba a dichas industrias, como a que estas representaban "....un poder electoral de enormes elementos generadores del poder legislativo" 191 .

Más claro aún era el doctor Francisco Landa cuando exponía ante los asistentes a la Quinta Conferencia Sanitaria Internacional de las Repúblicas Americanas, que dentro de las causas que explicaban el desarrollo del alcoholismo en Chile no podía olvidarse "...la gran influencia que han adquirido en los círculos de Gobierno y legislativos los viticultores y los comerciantes de sus productos; un rol importantísimo ha jugado y juega este vicio en la generación del sufragio y del poder

187 BSECD, 1900, sesión $41^{\text {a }}$ en 11 de enero de $1901,926$.

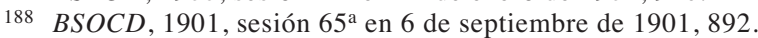

189 Antonio Cárdenas S. El alcoholismo en Chile. Sus causas i efectos, Memoria de prueba para optar al grado de licenciado en Leyes y Ciencias Políticas de la Universidad de Chile, Santiago de Chile, Imprenta y Encuadernación "El Globo", 1909, 38. La cita continua así: "La política, palabra halagadora para los que hacen de ella una profesión, es causal no pequeña del desarrollo de la epidemia alcohólica en nuestro suelo. Los choclones, téas incendiarias del alcoholismo, han constituido un programa obligado de la política. Allí, candidatos i electores arengan envueltos en los vapores del alcohol, allí el hombre del pueblo inconsciente i degradado vende su voto por una copa de mísero licor. Por otra parte, en lujosas cantinas, los ajentes electorales, que son todos en tiempos de elecciones, entonan himnos alentadores antes de la batalla, vitorean al vencedor o consuelan al derrotado, después de ella, entre las espumantes copas de la sidra o el champagne. De este modo la política, a más de ser la fuente de otros muchos vicios sociales, constituye uno de los factores que inyectan al alcohol en el organismo del pueblo con el beneplácito culpable de las autoridades i de la sociedad entera".

190 Samuel Radrigán A., op. cit., 11.

191 Hernán Correa R., op cit., 11. 
electoral, pervirtiendo, en su origen, el organismo administrativo del país. La taberna ha pasado a ser un verdadero poder público, y los taberneros elementos políticos y aún administrativos de gran influencia"192. Es decir, para el médico coincidían en movimientos paralelos tanto la presión de los viñateros en las altas esferas de la toma de decisiones, como el reclutamiento electoral de los taberneros en la superficie polvorienta de las elecciones municipales, configurándose así una alianza prácticamente imposible de vencer, y a la cual se unían, según la Sociedad Nacional de Agricultura, las autoridades judiciales, aun cuando no necesitaban del voto popular para su legitimación ${ }^{193}$.

Ya en vigencia la ley de 1916, la situación no se modificó en lo más mínimo, y por el contrario, las elecciones siguieron siendo motivo de crítica por el hecho de que al participar de ellas, el común de los votantes lo hacía en estado de ebriedad, o al menos bajo la promesa de poder embriagarse tras haber sufragado a favor de tal o cual candidato. El alcohol era, entonces, “...el más terrible enemigo de nuestra educación cívica de la masa ciudadana: de entre los degenerados por el licor sale el ejército de ciudadanos venales que decide nuestras contiendas políticas i encumbra al poder, no a los más aptos, sino a aquellos que van a defender intereses creados i que para ello pueden hacer fuertes desembolsos" 194 . Pero, junto a estos grandes intereses económicos, los que efectivamente ejercían el poder electoral, la convocatoria, la reunión, la suma de electores, eran -de acuerdo a un memorista que se detuvo con mayor extensión que otros en este hecho- los taberneros, que por medio de múltiples tácticas podían contar con un "mercado electoral" que ponían a disposición de quienes pudieran pagar mejor por él. Según sus palabras, no había casi parlamentario que no se preocupase, antes de su elección, si contaba o no con el apoyo de alguna parte del gremio de cantineros de su distrito, pues estos controlaban grupos de votantes a través de su conocimiento simpático de estos -por ser la taberna el club del obrero-, o por las deudas que amarraban a los trabajadores con los dueños de expendios, que vendían al fiado, actuaban como casas de empeño y prometían condonaciones o aplazamientos de estas deudas en recompensa por un determinado comportamiento electoral. Asimismo, y dadas las influencias y capitales que manejaban, los cantineros se habían convertido en los principales prestamistas de los pequeños almacenes de las localidades menores, asegurando de ese modo un nuevo conjunto de electores. A cambio de estos servicios, los elegidos se comprometían a no fiscalizar el cumplimiento de las ordenanzas y leyes que limitaban a las tabernas. Por tales condiciones, concluía nuestro autor, “...los comerciantes de licores son hoy un poder dentro de la nación, y si por

192 Francisco Landa, "Alcoholismo y anti-alcoholismo en Chile" En Higiene y Asistencia Pública en Chile. Homenaje de la Delegación de Chile a los Delegados Oficiales a la Quinta Conferencia Sanitaria Internacional de las Repúblicas Americanas (Celebrada en Santiago de Chile, del 5 al 12 de noviembre de 1911), Santiago de Chile, Imprenta, litografía y encuadernación Barcelona, 1911, 396-398.

193 BSNA, Vol. XLIV, $\mathrm{N}^{\circ}$ 8, agosto de 1913, 497-499.

194 Guillermo Tapia C., op. cit., 4-5. 
la ley no se pone a él un freno, llegará este poder a poner definitivamente un freno a la ley, y entonces contaremos aún, con un medio menos de defensa"195.

Todavía en 1925 un comentarista podía sindicar como principal obstáculo para la aplicación de las medidas centrales contra el alcoholismo en el país los intereses del sector viticultor, "...la industria de los grandes, de los poderosos de Chile, de los que con holgura compran los sillones parlamentarios" 196 . Y a un nivel más bajo, el doctor y activista antialcohólico Carlos Fernández Peña seguía considerando que las restricciones impuestas a las cantinas no eran cumplidas a cabalidad, “...porque su vigilancia está concedida a los mismos elegidos que dependen, para su reelección, en gran parte de los comerciantes al por menor" ${ }^{197}$. Es decir, los municipios, cuyo vínculo de dependencia con los capataces electorales de la cantina no se lograba debilitar. Como corolario, en 1934, un autor explicaba el fracaso de las medidas tendientes a limitar la producción y el expendio de vinos y licores debido a la "...influencia política y electoral de la mayoría de los productores"198.

\section{CONCLUSIONES}

Todo lo hasta ahora explicado nos permite establecer que los distintos planos de relaciones dadas entre la política y las bebidas alcohólicas a lo largo de nuestro periodo de estudio no experimentaron modificaciones de fondo, a pesar de las transformaciones que la legislación al respecto sí sufrió. En los sesenta años que hemos analizado, los productores de vinos y alcoholes de origen agrícola mantuvieron una posición de privilegio respecto a sus directos competidores -fueran importadores, destiladores industriales o cervecerías-, aun cuando las condiciones de tributación y reglamentación del expendio afectaran a todo el conjunto de la producción: en términos relativos, siempre los viñateros salieron favorecidos, y sus productos a la larga eran los sustitutos reales ante el encarecimiento del resto de las bebidas embriagantes. Ello se debió de forma explícita a la presencia de los intereses de la viticultura tanto en la agenda de los distintos gobiernos, como a la

195 Ignacio Ochagavía Hurtado, La legislación ante el problema del Alcoholismo. Estudio general de la Ley $\mathrm{N}^{\circ} 11.425$ sobre Alcoholes y en especial del Título V de la misma; seguido de un Proyecto de Ordenanza, que en conformidad al artículo 100 de dicha Ley, las Municipalidades, están obligadas a dictar. Memoria de prueba para optar al grado de licenciado en Leyes y Ciencias Políticas de la Universidad de Chile, Santiago de Chile, Imprenta Cervantes, 1917, 15-16.

196 Hugo Lea-Plaza, El alcoholismo en la región del Salitre (Discursos-Artículos- Cartas), Empresa periodística "La Nación", Santiago, 1925, 3.

197 Proyecto de Reforma de la Ley de Alcoholes. Redactado por el Dr. Carlos Fernández Peña por encargo de las tres instituciones [Asociación de Educación Nacional, Liga Chilena de Higiene Social y Liga Nacional contra el Alcoholismo] y en Defensa de la Raza, de la Viticultura y de la solución práctica del problema del alcoholismo., op. cit, 13.

198 Ramón Sánchez del Pozo, El ebrio en la legislación chilena y comentarios al Libro II de la actual Ley de Alcoholes. Represión del Alcoholismo, Memoria de prueba para optar al grado de Licenciatura en Ciencias Jurídicas y Sociales en la Universidad de Chile, Santiago de Chile, Imprenta de Carabineros de Chile, 1934, 10. 
efectiva influencia que los productores agrícolas lograban ejercer sobre las autoridades legislativas y administrativas. Si la denominada "oligarquía licorera" no gobernaba el país, al menos consiguió de forma sistemática que las distintas legislaciones que la afectaban se vieran de una u otra forma compensadas con excepciones de comercio, primas de exportación y fomento al desarrollo productivo, medidas todas que o no existían, o eran de menor magnitud para las otras industrias productoras. A fin de cuentas, el vino fue visto como una industria a desarrollar, aun para su sola exportación; por el contrario, las destilerías industriales, sin mayor presencia política en el Parlamento -salvo los representantes de las regiones australes-, parecían destinadas a extinguirse, dada la contundencia de las medidas en su contra y la ausencia casi total de estrategias factibles de transformación, como el uso industrial, la exportación o los desnaturalizantes.

Por otro lado, el hecho de que los recursos que el expendio de alcohol reportaba quedasen en manos de las municipalidades atomizó de forma evidente la capacidad de acción fiscal al respecto, en tanto que cada autoridad local arbitró de acuerdo a sus propios intereses estos montos, estableciendo compromisos que no necesariamente se vinculaban a los objetivos del poder central. El hecho de que los municipios mantuvieran la facultad de rematar y cobrar patentes implicó que junto con vulnerar las disposiciones de la legislación nacional, su dependencia económica de esta fuente de ingresos -no total, pero tampoco insignificante- los llevara a mantener una actitud laxa con respecto, por ejemplo, a la reglamentación sobre las tabernas. De esa forma, el principio de comuna autónoma permitió un margen de independencia efectiva en este aspecto del Estado central, con consecuencias que en el plano electoral quedarían una y otra vez de manifiesto. En el fondo, si bien las autoridades nacionales aplicaron medidas para encarecer, contener, regular e incluso reprimir el consumo de alcoholes, al momento de la puesta en práctica de estas estrategias fueron los municipios los que decidían si llevarlas a cabo no. Como el colonial "se acata pero no se cumple", las municipalidades acogían las medidas de combate contra la ebriedad -en particular la prisión por su manifestación pública, que los dotaba de mano de obra gratuita-, pero a la larga privilegiaban sus propias necesidades políticas y económicas antes que una adscripción unívoca a las normativas emanadas de la capital.

En un segundo plano, el acceso de los distintos actores del movimiento antialcohólico a las esferas del poder político, con críticas y juicios a veces lapidarios, también es un proceso digno de anotar. Si bien muchas de sus opiniones durante largo tiempo no fueron oídas, o al menos consideradas, estos movimientos que a través de sus medios de prensa ejercían una y otra vez el cuestionamiento, se demostraban como actores informados, dueños de un programa de acción que a pesar de su a primera vista radicales proposiciones, con el tiempo alcanzarían algunos logros de valor. A partir de la década de 1920 ello se hizo evidente, y la sola consecuencia de las asociaciones abstinentes con sus propios principios las alejó de la pasividad o el compromiso fácil con las opciones que el Estado tomaba en relación al problema de los alcoholes. Sí, puesto que ante la opción de la eliminación drástica de las industrias productoras o su explotación fiscal, los dis- 
tintos sectores del antialcoholismo chileno optaron sin dudar por la primera opción, en tanto las autoridades estatales insistieron en la segunda, atenazadas por las fluctuaciones inflacionarias, la disminución de los recursos provenientes del salitre y el crecimiento del Estado y sus funciones que caracterizó a las primeras décadas del siglo XX. Médicos, temperantes y secciones del movimiento obrero organizado hicieron del combate al consumo inmoderado de bebidas alcohólicas una bandera de lucha, pero el programa maximalista, a pesar de algunos a la larga fugaces triunfos, fue abandonado en función de sus propios intereses por aquel encargado de llevarlo a cabo, a su juicio, de forma cabal: el Estado. Pese a ello, sin embargo, la incorporación de estos sectores al debate público abierto por el problema de la ebriedad social y sus medios de solución fue un fenómeno ilustrativo de la capacidad de injerencia política de las distintas organizaciones sociales del Chile de la Cuestión Social, en términos de la coincidencia o crítica de las medidas -o desidias- que al respecto ponía en juego la autoridad central.

De esa forma, el consumo de alcohol se mantuvo a lo largo de las décadas analizadas como un componente relevante de la contienda política, y por ello los intereses puestos en juego en la persistencia de esta situación no fueron pocos. Operando los taberneros como capataces electorales tanto de los municipios como de las autoridades legislativas y nacionales, la disponibilidad efectiva de bebidas alcohólicas, y más aún, los compromisos personales, comerciales e institucionales derivadas de ella fueron un elemento que las clases políticas debieron tener en consideración al momento en que entraban a la lucha electoral. Ello implicó que aunque en los periodos exentos de votaciones populares las municipalidades, los diputados, los senadores y hasta el mismo Presidente de la República mantuviesen un discurso de rechazo a su consumo, a la hora de conseguir partidarios no trepidaron -de acuerdo a las fuentes- en utilizar la promesa de consumo, la borrachera como tal o el chantaje a quienes bebían al fiado para su propio provecho. Estando esta costumbre instalada en el corazón mismo de la práctica "democrática" chilena (junto al cohecho y el carneraje), la posición de los consumidores inmoderados no dejaba de ser paradójica: las mismas autoridades que un día los enviaban a prisión por su pública y manifiesta ebriedad, en una ocasión siguiente les invitaban los tragos, les condonaban sus deudas o, ya embriagados, los conminaban a votar ${ }^{199}$.

Si todo ello es comprensible desde las lógicas del funcionamiento político chileno de las últimas décadas del siglo XIX y las primeras del XX, también lo es desde la perspectiva de los procesos de incorporación a la vida política formal de amplios sectores de las clases operarias del país. Tal y como lo ha señalado Julio Pinto V. en un estudio referido a la zona de Tarapacá, el comportamiento político

199 Con respecto a la utilización en tiempos electorales del alcohol, Rene Millar explícitamente expresa que un medio de pago del cohecho, así como de parte de los patrones que llevaban a votar a sus empleados, era el alcohol. Del mismo modo, de su lectura se puede interpretar el papel de los taberneros en la constitución de contingentes de individuos dedicados a hostilizar y a la larga impedir el sufragio de los electores opuestos a uno u otro candidato. René Millar C., La elección presidencial de 1920. Tendencias y prácticas políticas en el Chile parlamentario. Editorial Universitaria, Santiago, 1981, 166-173. 
de los trabajadores del salitre estuvo marcado más que por su adscripción a los partidos de clase, a la sistemática votación por las agrupaciones tradicionales, asentadas en los modos de funcionamiento del parlamentarismo y claramente representantes de los intereses de los patrones antes que de los obreros. Con los riesgos que ello podía significar -la introducción al ámbito hasta entonces vedado de la política y su consiguiente radicalización por parte de sectores proletarios con propuestas de transformación social- los partidos oligárquicos estuvieron dispuestos a dar el paso de la politización popular, confiados -y a mediano plazo con razón- de que ello no socavaría su propia posición de dominación. De tal forma, la politización "desde arriba" fue un éxito, y no lesionó las bases de la política tradicional ${ }^{200}$.

Fecha de recepción: septiembre de 2005.

Fecha de aceptación: julio de 2006.

200 Julio Pinto V., “¿Cuestión social o cuestión política? La lenta politización de la sociedad popular tarapaqueña hacia el fin de siglo (1889-1900)", en Historia, Vol. 30, 1997, 211-261. 
